\title{
THE HYDROGEOLOGIC FRAMEWORK AND GEOCHEMISTRY OF THE COLUMBIA PLATEAU AQUIFER SYSTEM, WASHINGTON, OREGON, AND IDAHO
}

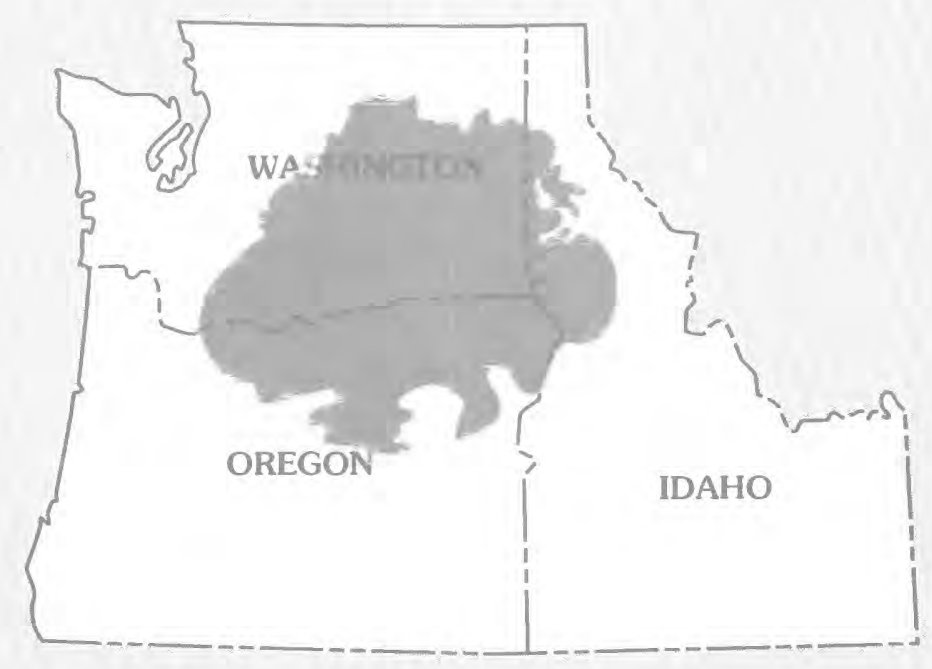

U. S. GEOLOGICAL SURVEY PROFESSIONAL PAPER 1413-B 


\section{AVAILABILITY OF BOOKS AND MAPS OF THE U.S. GEOLOGICAL SURVEY}

Instructions on ordering publications of the U.S. Geological Survey, along with prices of the last offerings, are given in the currentyear issues of the monthly catalog "New Publications of the U.S. Geological Survey." Prices of available U.S. Geological Survey publications released prior to the current year are listed in the most recent annual "Price and Availability List." Publications that are listed in various U.S. Geological Survey catalogs (see back inside cover) but not listed in the most recent annual "Price and Availability List" are no longer available.

Reports released through the NTIS may be obtained by writing to the National Technical Information Service, U.S. Department of Commerce, Springfield, VA 22161; please include NTIS report number with inquiry.

Order U.S. Geological Survey publications by mail or over the counter from the offices given below.

\section{BY MAIL}

\section{Books}

Professional Papers, Bulletins, Water-Supply Papers, Techniques of Water-Resources Investigations, Circulars, publications of general interest (such as leaflets, pamphlets, booklets), single copies of Earthquakes \& Volcanoes, Preliminary Determination of Epicenters, and some miscellaneous reports, including some of the foregoing series that have gone out of print at the Superintendent of Documents, are obtainable by mail from

\section{U.S. Geological Survey, Map Distribution Box 25286, MS 306, Federal Center Denver, CO 80225}

Subscriptions to periodicals (Earthquakes \& Volcanoes and Preliminary Determination of Epicenters) can be obtained ONLY from the

\section{Superintendent of Documents Government Printing Office Washington, DC 20402}

(Check or money order must be payable to Superintendent of Documents.)

\section{Maps}

For maps, address mail orders to

\section{U.S. Geological Survey, Map Distribution Box 25286, Bldg. 810, Federal Center Denver, CO 80225}

Residents of Alaska may order maps from

\author{
U.S. Geological Survey, Earth Science Information Center \\ 101 Twelfth Ave., Box 12 \\ Fairbanks, AK 99701
}

\section{OVER THE COUNTER}

\section{Books and Maps}

Books and maps of the U.S. Geological Survey are available over the counter at the following U.S. Geological Survey offices, all of which are authorized agents of the Superintendent of Documents.

- ANCHORAGE, Alaska-4230 University Dr., Rm. 101

- LAKEWOOD, Colorado-Federal Center, Bldg. 810

- MENLO PARK, California-Bldg. 3, Rm. 3128, 345 Middlefield Rd.

- RESTON, Virginia-National Center, Rm. 1C402, 12201 Sunrise Valley Dr.

- SALT LAKE CITY, Utah-Federal Bldg., Rm. 8105, 125 South State St.

- SPOKANE, Washington-U.S. Post Office Bldg., Rm. 135, W. 904 Riverside Ave.

- WASHINGTON, D.C.-Main Interior Bldg., Rm. 2650, 18th and C Sts., NW.

\section{Maps Only}

Maps may be purchased over the counter at the U.S. Geological Survey offices:

- FAIRBANKS, Alaska-New Federal Building, 101 Twelfth Ave.

- ROLLA, Missouri-1400 Independence Rd.

- STENNIS SPACE CENTER, Mississippi-Bldg. 3101 


\section{The Hydrogeologic Framework and Geochemistry of the Columbia Plateau Aquifer System, Washington, Oregon, and Idaho}

By K.J. WHITEMAN, J.J. VACCARO, J.B. GONTHIER, and H.H. BAUER REGIONAL AQUIFER-SYSTEM ANALYSIS-COLUMBIA PLATEAU, WASHINGTON-OREGON

U.S. GEOLOGICAL SURVEY PROFESSIONAL PAPER 1413-B

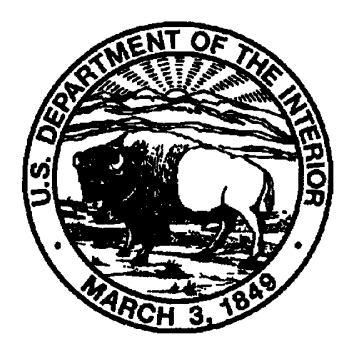

UNited STATES GOVERNMENT PRINTING OFFICE, WASHINGTON : 1994 


\section{U.S. DEPARTMENT OF THE INTERIOR \\ BRUCE BABBITT, Secretary}

\section{U.S. GEOLOGICAL SURVEY}

Robert M. Hirsch, Acting Director

Any use of trade, product, or firm names in this publication is for descriptive purposes only and does not imply endorsement by the U.S. Government.

Library of Congress Cataloging-in-Publication Data

The hydrogeologic framework and geochemistry of the Columbia Plateau aquifer system, Washington, Oregon, and Idaho / by K.J. Whiteman ... [et al.].

p. cm. - (Regional aquifer system analysis-Columbia Plateau, Washington-Oregon; ch. B) (U.S. Geological Survey professional paper ; 1413-B)

Includes bibliographical references.

1. Groundwater-Columbia Plateau. I. Whiteman, K. J. II. Series. III. Series: U.S. Geological Survey professional paper ; $1413-\mathrm{B}$.

GB1020.H49 1993

$553.7^{\prime} 9^{\prime} 09797-\mathrm{dc} 20$

93-23010

For sale by Book and Open-File Report Sales, U.S. Geological Survey Federal Center, Box 25286, Denver, CO 80225 


\section{FOREWORD}

\section{THE REGIONAL AQUIFER-SYSTEM ANALYSIS PROGRAM}

The Regional Aquifer-System Analysis (RASA) Program was started in 1978 following a congressional mandate to develop quantitative appraisals of the major ground-water systems of the United States. The RASA Program represents a systematic effort to study a number of the Nation's most important aquifer systems, which in aggregate underlie much of the country and which represent an important component of the Nation's total water supply. In general, the boundaries of these studies are identified by the hydrologic extent of each system and accordingly transcend the political subdivisions to which investigations have often arbitrarily been limited in the past. The broad objective for each study is to assemble geologic, hydrologic, and geochemical information, to analyze and develop an understanding of the system, and to develop predictive capabilities that will contribute to the effective management of the system. The use of computer simulation is an important element of the RASA studies, both to develop an understanding of the natural, undisturbed hydrologic system and the changes brought about in it by human activities, and to provide a means of predicting the regional effects of future pumping or other stresses.

The final interpretive results of the RASA Program are presented in a series of U.S. Geological Survey Professional Papers that describe the geology, hydrology, and geochemistry of each regional aquifer system. Each study within the RASA Program is assigned a single Professional Paper number, and where the volume of interpretive material warrants, separate topical chapters that consider the principal elements of the investigation may be published. The series of RASA interpretive reports begins with Professional Paper 1400 and thereafter will continue in numerical sequence as the interpretive products of subsequent studies become available.

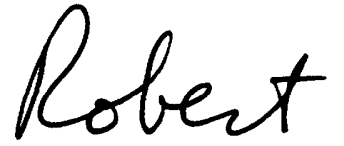<smiles>[Te]</smiles><smiles>CC(C)CC1CCCCC1C</smiles>

Robert M. Hirsch Acting Director 



\section{CONTENTS}

Page

Abstract

Introduction

Purpose and scope

Previous investigations

Acknowledgments

Physical setting

Physiography

Climate

Cultural setting -

Water-resource and economic development

Hydrogeologic framework

Geology

Overburden

Columbia River Basalt Group

Geologic structures

Internal structure of basalt flows
B1 Hydrogeologic framework-Continued

Geology-Continued

Basalt rock mechanics -...-...-- B30

Hydrology

Relation between geologic and hydrologic

frameworks

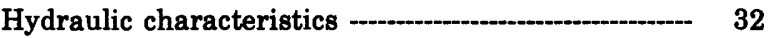

Recharge and discharge -..-- 40

Ground-water development -_.._._. $\quad 50$

Regional flow system --..- 50

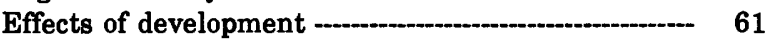

Geochemistry

Chemical evolution of the ground water -...- 65

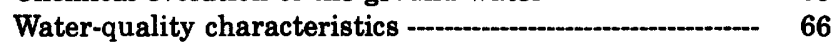

Summary and conclusions - - 68

References cited -

\section{ILLUSTRATIONS}

Figure 1. Map showing location of the Columbia Plateau aquifer system and physiographic subprovince boundaries

2. Map showing mean annual precipitation in the Columbia Plateau, 1956-77

Page

3-6. Graphs showing:

3. Mean monthly distribution of precipitation at 103 weather stations, 1956-77

B3

4. Mean minimum, mean, and maximum daily air temperatures at 89 weather stations, $1956-77$

5. Number of farms with irrigated lands and average farm size, 1949-82

6. Population of the Columbia Plateau area, 1900-80

7. Map showing generalized surficial geology and stratigraphic chart for the Columbia Plateau

8. Map showing extent and thickness of overburden where its thickness is generally 50 feet or more -

9. Generalized geologic sections through the Columbia Plateau

10-18. Maps showing:

10. Thickness of the Grande Ronde Basalt and older basalts - 19

11. Altitude of the top of the Grande Ronde Basalt -

12. Thickness of the Wanapum-Grande Ronde interbed -

13. Thickness of the Wanapum Basalt and interbedded sediments -

14. Altitude of the top of the Wanapum Basalt

15. Thickness of the Saddle Mountains-Wanapum interbed -

16. Thickness of the Saddle Mountains Basalt and interbedded sediments

17. Altitude of the top of the Saddle Mountains Basalt - 27

18. Major geologic structures within the Columbia Plateau

19. Generalized diagram showing a typical basalt flow in the Columbia River Basalt Group - 30

20. Chart showing correlation of geologic framewor:s with hydrologic framework -- 33

21. Sketch of generalized ground-water-flow pattern in the Columbia Plateau aquifer system - 34

22. Map showing relation of the hydrologic study area, the areal extent of the Columbia River Basalt Group, and

the Columbia Plateau Regional Aquifer-System Analysis study area

23. Graph showing frequency distribution of hydraulic-conductivity data for the overburden aquifer

24. Map showing areal distribution of hydraulic conductivity for the overburden aquifer -.

25. Graph showing frequency distribution of lateral hydraulic conductivities for the three basalt units

26. Graph showing frequency distribution of thickness of the Columbia Plateau aquifer system -

27. Graphs showing frequency distribution of thickness for the three basalt units 
FIGURE 28. Schematic diagram showing the conceptual model of the energy balance for evapotranspiration

29. Schematic diagram showing the conceptual model of the water balance used in the deep-percolation model -.-.-.-...-.- 43

30-34. Maps showing:

30. Land-use classification of the Columbia Plateau, 1975 - 44

31. Estimates of recharge in each of 53 selected basins -

32. Distribution of estimated recharge under predevelopment (1850's) conditions -

33. Distribution of estimated recharge under current (1980's) conditions -

34. Distribution of estimated recharge under predevelopment (1850's) and current (1980's) conditions in an arid zone

36-44. Maps showing:

36. Ground-water pumpage from the overburden aquifer, 1984

37. Ground-water pumpage from the Saddle Mountains unit,

38. Ground-water pumpage from the Wanapum unit, 1984

39. Ground-water pumpage from the Grande Ronde unit, 1984

54

41. Water table in the overburden aquifer representing conditions during the spring of 1983

42. Water-level contours for the Saddle Mountains unit, spring 1985

43. Water-level contours for the Wanapum unit, spring 1985

44. Water-level contours for the Grande Ronde unit, spring 1985

45. Hydrographs showing seasonal water-level fluctuations for selected piezometers

46. Map showing water-level changes in the Wanapum unit from predevelopment (1850's) to 1985

47. Hydrographs of water levels in selected wells, showing long-term water-level changes - 64

48. Graphs showing relation of chemical water type in the Saddle Mountains unit to well depth and overburden thickness -

49. Bar graphs showing relation of chemical water type in the Wanapum unit to well depth, dissolved-oxygen concentration, and overburden thickness

\section{TABLES}

TABLE 1. Mean annual precipitation at selected weather stations, 1956-77

2. Mean air temperature data from selected weather stations, $1956-77$

3. Reservoirs in the study area having storage capacity greater than 40,000 acre-feet

4. Rock-mechanics data for the Columbia River Basalt Group -

5. Summary of selected estimates of storage coefficient for the Columbia Plateau aquifer system

6. Computed long-term, averaged monthly water budget for a semiarid zone and a temperate zone

7. Summary of selected water chemistry for the three basalt units

\section{METRIC CONVERSION FACTORS AND VERTICAL DATUM}

\begin{tabular}{|c|c|c|}
\hline Multiply inch-pound unit & By & To obtain metric unit \\
\hline inch (in.) & 25.4 & millimeter \\
\hline foot (ft) & 0.3048 & meter \\
\hline mile (mi) & 1.609 & kilometer \\
\hline square foot $\left(\mathrm{ft}^{2}\right)$ & 0.0929 & square meter \\
\hline acre & 0.4047 & hectare \\
\hline square mile $\left(\mathrm{mi}^{2}\right)$ & 2.59 & square kilometer \\
\hline acre-foot (acre-ft) & 0.001233 & cubic hectometer \\
\hline foot per day $(\mathrm{ft} / \mathrm{d})$ & 0.3048 & meter per day \\
\hline cubic foot per second $\left(\mathrm{ft}^{3} / \mathrm{s}\right)$ & 0.02832 & cubic meter per second \\
\hline gallon per minute $(\mathrm{gal} / \mathrm{min})$ & 0.06308 & liter per second \\
\hline ton, short & 0.9072 & megagram \\
\hline pound pèr square inch $\left(\mathrm{lb} / \mathrm{in}^{2}\right)$ & 70.31 & gram per square centimeter \\
\hline pound per cubic inch $\left(\mathrm{lb} / \mathrm{in}^{3}\right)$ & 27.68 & gram per cubic centimeter \\
\hline \multicolumn{3}{|c|}{$\begin{array}{l}\text { to change degrees Fahrenheit }\left({ }^{\circ} \mathrm{F}\right) \text { to degrees Celsius }\left({ }^{\circ} \mathrm{C}\right):{ }^{\circ} \mathrm{C}=5 / 9\left({ }^{\circ} \mathrm{F}-32\right) \\
\text { to change degrees Celsius }\left({ }^{\circ} \mathrm{C}\right) \text { to degrees Fahrenheit }\left({ }^{\circ} \mathrm{F}\right):{ }^{\circ} \mathrm{F}=9 / 5{ }^{\circ} \mathrm{C}+32\end{array}$} \\
\hline
\end{tabular}

Sea Level: In this report "sea level" refers to the National Geodetic Vertical Datum of 1929-a geodetic datum derived from a general adjustment of the first-order level nets of both the United States and Canada, formerly called "Sea Level Datum of 1929." 


\title{
THE HYDROGEOLOGIC FRAMEWORK AND GEOGHEMISTRY OF THE COLUMBIA PLATEAU AQUIFER SYSTEM, WASHINGTON, OREGON, AND IDAHO
}

\author{
By K.J. Whiteman, J.J. Vaccaro, J.B. Gonthier, and H.H. Bauer
}

\begin{abstract}
The Columbia Plateau aquifer system underlies about 50,600 square miles in parts of Washington, Oregon, and Idaho. The aquifer system is a major source of water for municipal, industrial, domestic, and irrigation uses. About 828,270 acrefeet of water was pumped in 1984,85 to 90 percent of which was used to irrigate about 0.5 million acres of croplands. An additional 1.3 million acres of croplands were irrigated with surface water.

The Columbia Plateau aquifer system consists of waterbearing Miocene basalt of the Columbia River Basalt Group, minor amounts of Miocene sedimentary rocks interlayered with the basalt, and Miocene to Holocene sediments overlying the basalt. The basalts are underlain by sedimentary, igneous, and metamorphic rocks older than the Columbia River Basalt Group, dating from Precambrian to early Tertiary age. The most important geologic units in the aquifer system are three formations belonging to the Yakima Basalt Subgroup of the Columbia River Basalt Group: from oldest to youngest, the Grande Ronde, Wanapum, and Saddle Mountains Basalts. The average total thickness of the basalts is 3,300 feet, with a maximum thickness exceeding 10,000 feet in the central part of the plateau.

For study purposes, the aquifer system was divided into seven hydrogeologic units-the overburden aquifer, the Saddle Mountains unit, the Wanapum unit, the Grande Ronde unit, two confining units between the basalt units, and a basement confining unit. The basalt units include the interbedded sediments.

Lateral hydraulic conductivity of the aquifer materials varies widely, reflecting the heterogeneous nature of the aquifer system. Estimated hydraulic conductivity values for the overburden aquifer range from 0.02 to 150,000 feet per day, and for the basalt units, from 0.005 to 6,100 feet per day.

Discharge from the aquifer system occurs mainly as seepage to surface-water bodies in topographic lows, as pumpage of ground water, and as springs and seeps along canyon, coulee, and valley walls. Except for the ground-water pumpage, discharge cannot be accurately quantified. Recharge, which was estimated by using a daily water-budget model, is about 6,000 cubic feet per second for predevelopment (1850's) conditions and about 9,490 cubic feet per second for current (1980's) conditions.

Water levels in the uppermost basalt unit and in the overlying sediments tend to parallel the land surface, and ground water moves generally from topographic highs to topographic
\end{abstract}

lows. Ground water in each hydrogeologic unit generally flows from the peripheral boundary of each unit toward major surfacewater bodies, principally the Columbia, Snake, and Yakima Rivers. Geologic structures such as faults and folds modify this flow pattern. Ground-water pumpage has caused water levels to decline more than $\mathbf{1 5 0}$ feet locally, and imported surface water applied for irrigation has caused water levels to rise as much as 300 feet in parts of the area.

Ground-water development began about 1890. Pumpage has increased from an estimated 55,690 acre-feet in 1945 , to 177,970 acre-feet in 1960 , and to a peak of about 939,770 acrefeet by 1979 .

The water in the basalts is generally suitable for most uses. The dominant water type is calcium magnesium bicarbonate, followed by sodium bicarbonate water type. Dissolved-solids concentrations increase down gradient and range from 69 to 1,100 milligrams per liter. Nitrogen concentrations range from 0.1 to 54 milligrams per liter and average about 3.7. Nitrogen concentrations in ground water are greater in areas irrigated by surface water than in other areas.

\section{INTRODUCTION}

The Columbia Plateau aquifer system underlies the Columbia Plateau of central and eastern Washington, north-central and northeastern Oregon, and a small part of northwestern Idaho (fig. 1) for a total area of about $50,600 \mathrm{mi}^{2}$. The aquifer system consists of Miocene basalt belonging to the Columbia River Basalt Group, Miocene sedimentary rocks interlayered with the basalt, and Miocene to Holocene sediments overlying the basalts. The aquifer system is a major source of water for municipal, industrial, domestic, and irrigation uses. Concurrent with ground-water usage, imported surface water is used for irrigation in several areas of the plateau. Use of surface water for irrigation has caused ground-water-level rises of as much as 300 $\mathrm{ft}$ in some areas; water levels have declined more than $150 \mathrm{ft}$ in areas of ground-water pumpage, and 
the chemical quality of ground water has changed in irrigated areas. An improved understanding of the aquifer system, especially the movement and direction of ground-water flow, is needed to fully address these concerns.

\section{PURPOSE AND SCOPE}

The Columbia Plateau aquifer system is one of several regional aquifers selected for study as part of the U.S. Geological Survey's Regional AquiferSystem Analysis (RASA) Program. The objectives of the Columbia Plateau study are to describe (1) the hydrogeologic framework, (2) the hydrologic characteristics of the hydrogeologic units, (3) the area's water budget, (4) the ground-water and surfacewater interaction, and (5) the water-quality characteristics and water-rock interactions that occur in the study area. In order to provide the analytical capabilities for assessment of management alternatives and to allow a better understanding of the ground-water flow system, a numerical model that simulates ground-water movement has been constructed.

This report documents the following information collected from the study: (1) the physical, cultural, and economic settings, (2) the geologic framework, (3) the hydrologic characteristics of major geohydrologic units, (4) some components of the water budget, (5) the regional ground-water flow system, and (6) the geochemistry of the aquifer system.

\section{PREVIOUS INVESTIGATIONS}

Numerous geologic, hydrologic, and hydrogeologic investigations within or including the Columbia Plateau have been done. These investigations have laid the foundation for the work completed during this study. Smith $(1901,1903 a, b, c)$ conducted early geologic mapping on the plateau and suggested stratigraphic nomenclature for the basalts. His work was confined to the area of the Columbia Lava delineated by Russell (1893, 1897). Later investigators who expanded the knowledge of the geology and nomenclature of the basalts included Pardee and Bryan (1926), Fuller (1931), Waters (1955, 1961), Mackin (1961), Grolier and Foxworthy (1961), Bingham and Walters (1965), Schmincke (1965, 1967a, b), Swanson (1967), Bingham and Grolier (1966), and Diery and McKee (1969). Starting in the early 1970's, geologic investigations on the plateau were many and diverse. The stratigraphic nomenclature report of Swanson and others (1979c) gives a good background on these investigations. Finally, the work of Swanson and others $(1979 a, b, 1981)$ was the basis for the geologic work completed during this study.

Early water-resources investigations included the studies of Calkins (1905), Waring (1913), Schwennesen and Meinzer (1918), Piper (1932), and Taylor (1948). Since the mid-1950's, numerous investigations have been completed on the plateau. Some of the more important reports and investigations are referred to in subsequent sections of the present report.

\section{ACKNOWLEDGMENTS}

The State of Washington Department of Ecology assisted the U.S. Geological Survey during the water-level-data collection phase of this RASA project and cooperated with the Geological Survey in determining the rate and distribution of groundwater pumpage. In addition, previous studies made cooperatively by the Department of Ecology and the Geological Survey provided a foundation for the geology and water-quality results summarized in this report. The cooperation of numerous residents of the Columbia Plateau who have permitted the Geological Survey to measure water levels and collect water samples from their wells is also appreciated.

\section{PHYSICAL SETTING}

The Columbia Plateau lies within the Columbia intermontane physiographic province (Freeman and others, 1945). It is bordered by the Cascade Range on the west, by the Okanogan Highlands on the north, and by the Rocky Mountains on the east; its southern boundary is defined more by the extent of the Columbia River Basalt Group than by any physiographic feature. The Columbia Plateau is drained by the Columbia River and its major tributaries-the Snake, Yakima, John Day, Umatilla, Spokane, Klickitat, and Deschutes Rivers. Although physiographers refer to it as a plateau, the Columbia Plateau is in reality both a structural and a topographic basin with its lowest point near Pasco, Wash. (fig. 1).

\section{PHYSIOGRAPHY}

The Columbia Plateau is underlain everywhere by massive basalt flows having an estimated composite thickness of about $14,000 \mathrm{ft}$ at the plateau's 
low point near Pasco, Wash. The characteristics of the older rocks overlain by the Columbia River Basalt Group are distinguishable only at exposures in the highlands surrounding the plateau. In the

interior of the province, the lithology, structure, and topography of the prebasalt rocks cannot be readily determined because the rocks are buried beneath the thick accumulation of lava. Sedimentary
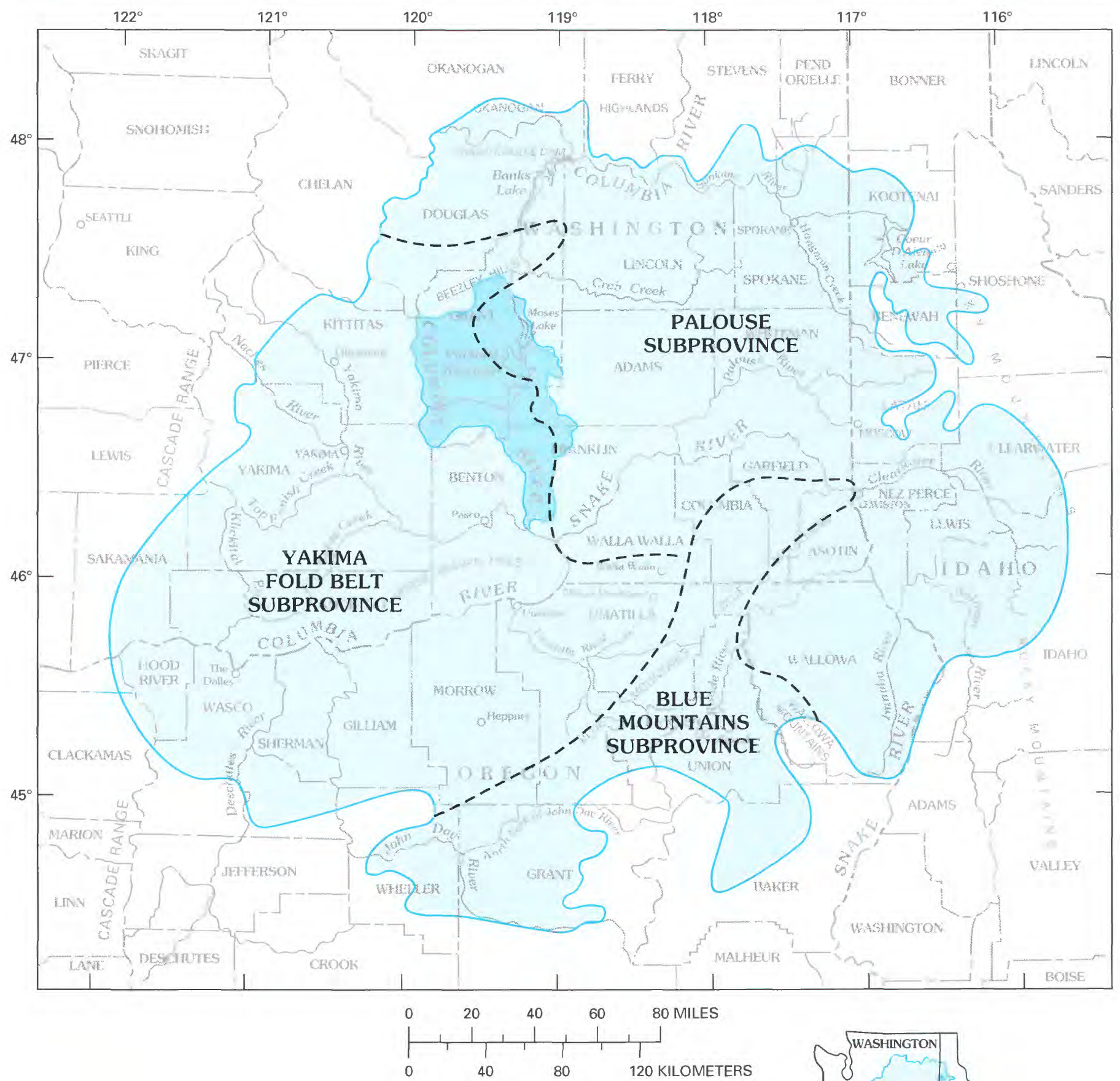

EXPLANATION

COLUMBIA BASIN IRRIGATION PROJECT

COLUMBIA PLATEAU AQUIFER SYSTEM STUDY BOUNDARY

- - - PHYSIOGRAPHIC SUBPROVINCE BOUNDARY

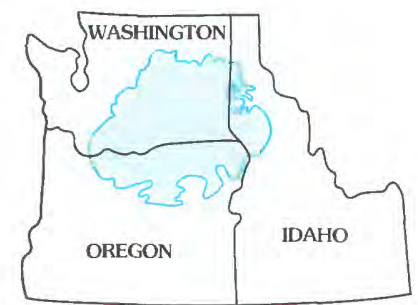

INDEX MAP OF STUDY AREA

FIgURE 1.-Location of the Columbia Plateau aquifer system and physiographic subprovince boundaries. 
deposits overlie the basalt over large areas of the plateau, exceeding $1,200 \mathrm{ft}$ in thickness in the Yakima River valley and $2,000 \mathrm{ft}$ in the Grande Ronde valley near La Grande, Oregon.

The Columbia Plateau was divided into three informal physiographic subprovinces by Myers and Price (1979)_the Yakima Fold Belt, Blue Mountains, and Palouse subprovinces (fig. 1). The Yakima Fold Belt includes most of the western half of the plateau north of the crest of the Blue Mountains and is characterized by a series of ridges and basins. The Palouse subprovince occupies the northeast quarter of the plateau in Washington, north of the Blue Mountains, and extends eastward into Idaho. It consists of nearly undeformed basalt with a gentle southwest slope, on which a rolling topography of loessal hills is developed. The Blue Mountains subprovince comprises all the Columbia Plateau in Oregon and Washington south and east of the Blue Mountains, including a series of folds extending into Idaho near Lewiston. This subprovince is characterized by higher plateaus, deeply dissected by many streams.

The topography in central Washington, commonly referred to as the "channeled scablands," was produced during Pleistocene time. Catastrophic floods, resulting from the breakup of glacial ice daris that impounded large lakes in western Montana and northern Idaho, carved spectacular erosional features into the basalt plateau. Floodwaters stripped away overlying sediments and left behind deep canyons and coulees, rugged cliffs and buttes, large gravel bars, and giant ripple marks that measure 20 to $30 \mathrm{ft}$ in height. Thick layers of sediment were deposited in low areas where floodwaters spread, slowed, and ponded. These slack-water deposits approach a thickness of $300 \mathrm{ft}$ at several localities.

The types and amounts of natural vegetation found on the Columbia Plateau are largely dependent on condivions of precipitation and land-surface altitudes. In the central part of the plateau, where the land surface ranges from 350 to $2,000 \mathrm{ft}$ above sea level and the precipitation ranges from 7 to $15 \mathrm{in} / \mathrm{yr}$, the vegetation is principally sagebrush and grasslands, and there are few perennial streams. At altitudes ranging from 2,000 to $3,500 \mathrm{ft}$, the vegetation is typical of semiarid climates and includes both grasslands and forest. These areas generally receive from 15 to $25 \mathrm{in}$. of precipitation annually. Where altitudes range from 3,500 to $6,000 \mathrm{ft}$, forest lands predominate and small perernial streams in deep canyons are common. The mountains bordering the Columbia Plateau locally receive more than 100 in. of precipitation per year. The mountainous topography is typically rugged and steep with a patchwork of barren rock and conifer forests.

\section{CLIMATE}

Most of the Columbia Plateau is semiarid and receives less than 15 in. of precipitation annually. Mean annual precipitation ranges from about 7 in. in the center of the study area to more than $45 \mathrm{in}$. in the surrounding forested mountains. From the east slope of the Cascade Range, at about $2,000 \mathrm{ft}$ altitude, to the westernmost extent of the study area, the mean annual precipitation is as much as 100 in. Precipitation is greater in the Cascade Range to the west than at similar altitudes in the Blue Mountains to the southeast. The mean annual precipitation for the Columbia Plateau for the period 1956 to 1977 (Nelson, 1991) is shown in figure 2, and information for the weather sites is given in table 1.

The temporal distribution of annual precipitation is similar throughout the study area. The mean monthly precipitation, based on data for 103 weather stations (fig. 3), is greatest in December and January and least in July (Nelson, 1991). Typically, about 83 percent of the precipitation occurs during October through May, when air temperatures are less than the yearly average. Approximately 42 percent of the total annual precipitation falls from November through January. Winter snowfall ranges from 8 to $20 \mathrm{in}$. in the central pla. teau and from 70 to 300 in. at higher altitudes in the Cascade Range and Blue Mountains.

Mean air temperature data for the period 1956 to 1977 at 89 weather stations located throughout the Columbia Plateau are shown in table 2. The mean daily minimum, maximum, and average air temperatures at these weather stations for the period 1956 to 1977 are shown in figure 4. Minimum temperatures range from about $3^{\circ} \mathrm{C}$ in the low-lying areas to about $-3^{\circ} \mathrm{C}$ in the higher altitudes, and maximum temperatures range from about $19^{\circ} \mathrm{C}$ in the central plateau to about $12^{\circ} \mathrm{C}$ in the mountainous areas. Mean daily temperature fluctuations range from $8^{\circ} \mathrm{C}$ in winter to $20^{\circ} \mathrm{C}$ in summer. The seasonal extremes of temperature vary by about $40^{\circ} \mathrm{C}$ between winter lows and summer highs.

The percentage of sunshine increases from 10 percent in the winter to 50 percent in the spring and fall, and to 75 percent in the summer. In response to the climate variations, the growing season ranges from about 220 days at Walla Walla, Wash., to less than 100 days in the Cascade Range and Blue Mountains. 


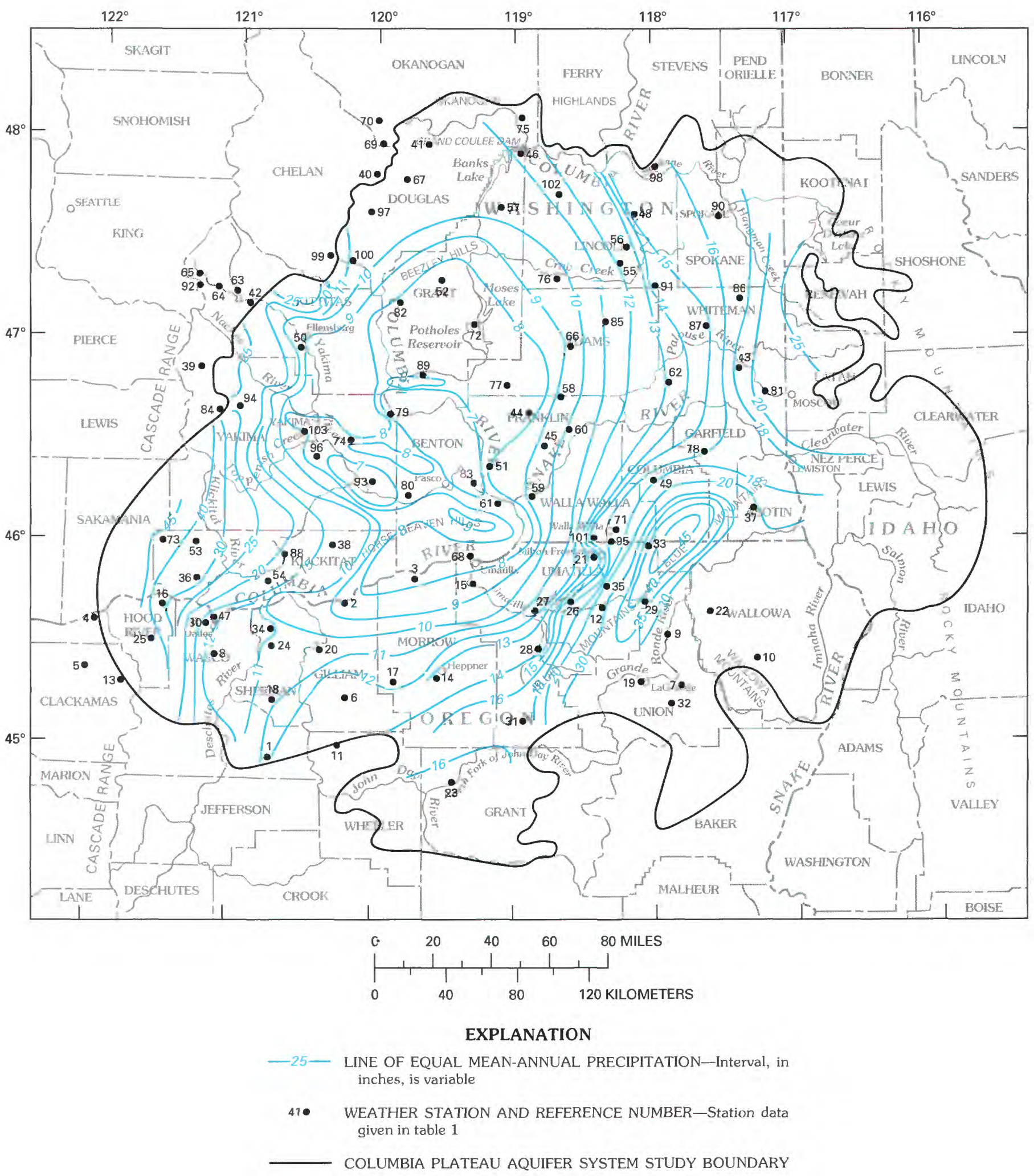

Figure 2.-Mean annual precipitation in the Columbia Plateau, 1956-77. (Modified from Nelson, 1991.) 
TABLE 1.-Mean annual precipitation at selected weather stations, 1956-77 (from Nelson, 1991)

\begin{tabular}{|c|c|c|c|c|c|c|}
\hline \multirow{2}{*}{$\begin{array}{l}\text { Weather- } \\
\text { station } \\
\text { reference } \\
\text { number } \\
\text { (see fig. 2) }\end{array}$} & \multirow[b]{2}{*}{$\begin{array}{c}\text { Index } \\
\text { number }\end{array}$} & \multirow[b]{2}{*}{$\begin{array}{l}\text { Weather } \\
\text { station }\end{array}$} & \multirow{2}{*}{$\begin{array}{c}\text { Station } \\
\text { altitude } \\
\text { (feet) }\end{array}$} & \multicolumn{2}{|c|}{ Location } & \multirow{2}{*}{$\begin{array}{c}\text { Annual } \\
\text { precipi- } \\
\text { tation } \\
\text { (inches) }\end{array}$} \\
\hline & & & & $\begin{array}{l}\text { Longitude } \\
\text { (decima) }\end{array}$ & $\begin{array}{l}\text { Latitude } \\
\text { egree) }\end{array}$ & \\
\hline 1 & $35-197$ & Antelope & 2,680 & 120.7167 & 44.9167 & 12.23 \\
\hline 2 & $35-265$ & Arlington & 285 & 120.2000 & 45.7167 & 8.56 \\
\hline 3 & $35-858$ & Boardman & 300 & 119.7000 & 45.8333 & 7.87 \\
\hline 4 & $35-897$ & Bonneville Dam & 60 & 121.9500 & 45.6333 & 75.64 \\
\hline 5 & $35-1028$ & Brightwood & 1,065 & 122.0167 & 45.3667 & 87.89 \\
\hline 6 & $35-1765$ & Condon & 2,830 & 120.1833 & 45.2333 & 13.40 \\
\hline 7 & $35-1924$ & Cove & 2,920 & 117.8000 & 45.3000 & 16.32 \\
\hline 8 & $35-2440$ & Dufur & 1,330 & 121.1333 & 45.4500 & 11.57 \\
\hline 9 & $35-2597$ & Elgin & 2,655 & 117.9167 & 45.5667 & 24.25 \\
\hline 10 & $35-2672$ & Enterprise & 3,790 & 117.2667 & 45.4333 & 12.82 \\
\hline 11 & $35-3038$ & Fossil & 2,650 & 120.2167 & 45.0000 & 13.80 \\
\hline 12 & $35-3250$ & Gibbon & 1,740 & 118.3667 & 45.7000 & 23.93 \\
\hline 13 & $35-3402$ & Government camp & 3,980 & 121.7500 & 45.3000 & 88.26 \\
\hline 14 & $35-3827$ & Heppner & 1,950 & 119.5500 & 45.3500 & 13.29 \\
\hline 15 & $35-3847$ & Hermiston $2 \mathrm{~S}$. & 624 & 119.2833 & 45.8167 & 8.57 \\
\hline 16 & $35-4003$ & Hood River Exp. Sta. & 500 & 121.5167 & 45.6833 & 30.59 \\
\hline 17 & $35-4161$ & Ione $18 \mathrm{~S}$ & 2,130 & 119.8500 & 45.3167 & 11.60 \\
\hline 18 & $35-4411$ & Kent & 2,720 & 120.7000 & 45.2000 & 11.12 \\
\hline 19 & $35-4622$ & La Grande & 2,755 & 118.0833 & 45.3167 & 17.26 \\
\hline 20 & $35-5545$ & Mikkalo $6 \mathrm{~W}$. & 1,550 & 120.3500 & 45.4667 & 10.19 \\
\hline 21 & $35-5593$ & Milton Freewater & 970 & 118.4167 & 45.9500 & 13.20 \\
\hline 22 & $35-5610$ & Minam $7 \mathrm{NE}$. & 3,615 & 117.6000 & 45.6833 & 26.82 \\
\hline 23 & $35-5711$ & Monument 2 & 1,995 & 119.4167 & 44.8167 & 13.12 \\
\hline 24 & $35-5734$ & Moro & 1,870 & 120.7167 & 45.4833 & 10.58 \\
\hline 25 & $35-6468$ & Parkdale 2 SSE. & 1,890 & 121.5833 & 45.5000 & 44.97 \\
\hline 26 & $35-6540$ & Pendleton Exp. Sta. & 1,487 & 118.6333 & 45.7167 & 15.68 \\
\hline 27 & $35-6546$ & Pendleton WSO AP & 1,492 & 118.8500 & 45.6833 & 11.73 \\
\hline 28 & $35-6634$ & Pilot Rock 1 SE. & 1,720 & 118.8167 & 45.4833 & 13.63 \\
\hline 29 & $35-8000$ & Spout Spgs Ski Lodge & 5,035 & 118.0500 & 45.7500 & 35.38 \\
\hline 30 & $35-8407$ & The Dalles & 102 & 121.2000 & 45.6000 & 13.51 \\
\hline 31 & $35-8726$ & Ukiak & 3,355 & 118.9333 & 45.1333 & 16.77 \\
\hline 32 & $35-8746$ & Union Exp. Sta. & 2,765 & 117.8833 & 45.2167 & 13.74 \\
\hline 33 & $35-8985$ & Walla Walla 13 ESE. & 2,400 & 118.0500 & 46.0000 & 41.77 \\
\hline 34 & $35-9068$ & Wasco & 1,264 & 120.7000 & 45.5833 & 11.01 \\
\hline 35 & $35-9219$ & Weston 5 ESE. & 3,200 & 118.3333 & 45.8000 & 26.09 \\
\hline 36 & $45-217$ & Appleton & 2,336 & 121.2667 & 45.8167 & 31.50 \\
\hline 37 & $45-294$ & Asotin 14 SW. & 3,500 & 117.2500 & 46.2000 & 19.20 \\
\hline 38 & $45-668$ & Bickleton & 3,000 & 120.3000 & 46.0000 & 13.93 \\
\hline 39 & $45-969$ & Bumping Lake & 3,440 & 121.3000 & 46.8667 & 36.90 \\
\hline 40 & $45-1350$ & Chelan & 1,120 & 120.0333 & 47.8333 & 10.31 \\
\hline 41 & $45-1400$ & Chief Joseph Dam & 820 & 119.6500 & 48.0000 & 9.45 \\
\hline 42 & $45-1504$ & Cle Elum & 1,930 & 120.9500 & 47.1833 & 24.65 \\
\hline 43 & $45-1586$ & Colfax $1 \mathrm{NW}$. & 1,955 & 117.3833 & 46.8833 & 19.29 \\
\hline 44 & $45-1690$ & Connell $1 \mathrm{~W}$. & 1,020 & 118.8833 & 46.6667 & 7.58 \\
\hline 45 & $45-1691$ & Connell $12 \mathrm{SE}$. & 1,078 & 118.7667 & 46.5000 & 9.45 \\
\hline 46 & $45-1767$ & Coulee Dam $1 \mathrm{SW}$. & 1,700 & 119.0000 & 47.9500 & 10.08 \\
\hline 47 & $45-1968$ & Dallesport FAA AP & 240 & 121.1500 & 45.6167 & 12.75 \\
\hline 48 & $45-2007$ & Davenport & 2,460 & 118.1500 & 47.6500 & 15.10 \\
\hline 49 & $45-2030$ & Dayton 1 WSW. & 1,557 & 118.0000 & 46.3167 & 18.16 \\
\hline 50 & $45-2505$ & Ellensburg & 1,480 & 120.5500 & 46.9667 & 9.47 \\
\hline 51 & $45-2542$ & Eltopia 8 WSW. & 700 & 119.1667 & 46.4000 & 8.09 \\
\hline 52 & $45-2614$ & Ephrata FAA AP & 1,259 & 119.5167 & 47.3167 & 7.11 \\
\hline 53 & $45-3183$ & Glenwood 2 & 1,850 & 121.2833 & 46.0000 & 35.06 \\
\hline 54 & $45-3226$ & Goldendale $2 \mathrm{E}$. & 1,800 & 120.7667 & 45.8167 & 16.39 \\
\hline 55 & $45-3502$ & Harrington $5 \mathrm{~S}$. & 2,170 & 118.2500 & 47.4167 & 12.18 \\
\hline 56 & $45-3512$ & Harrington 4 ENE. & 2,266 & 118.1833 & 47.4833 & 12.82 \\
\hline 57 & $45-3529$ & Hartline & 1,910 & 119.1000 & 47.6833 & 10.38 \\
\hline 58 & $45-3546$ & Hatton 9 ESE. & 1,430 & 118.6500 & 46.7500 & 9.79 \\
\hline 59 & $45-3883$ & Ice Harbor Dam & 368 & 118.8667 & 46.2500 & 9.07 \\
\hline 60 & $45-4077$ & Kahlotus 5 SSW. & 1,550 & 118.6000 & 46.5833 & 10.43 \\
\hline 61 & $45-4154$ & Kennewick & 390 & 119.1000 & 46.2167 & 7.35 \\
\hline 62 & $45-4338$ & La Crosse & 1,480 & 117.8833 & 46.8167 & 13.33 \\
\hline 63 & $45-4394$ & Lake Cle Elum & 2,250 & 121.0667 & 47.2444 & 37.27 \\
\hline
\end{tabular}


TABLE 1.-Mean annual precipitation at selected weather stations, 1956-77 (from Nelson, 1991)Continued

\begin{tabular}{|c|c|c|c|c|c|c|}
\hline \multirow{2}{*}{$\begin{array}{l}\text { Weather- } \\
\text { station } \\
\text { reference } \\
\text { number } \\
\text { (see fig. 2) }\end{array}$} & \multirow[b]{2}{*}{$\begin{array}{c}\text { Index } \\
\text { number }\end{array}$} & \multirow[b]{2}{*}{$\begin{array}{l}\text { Weather } \\
\text { station }\end{array}$} & \multirow{2}{*}{$\begin{array}{l}\text { Station } \\
\text { altitude } \\
\text { (feet) }\end{array}$} & \multicolumn{2}{|c|}{ Location } & \multirow{2}{*}{$\begin{array}{c}\text { Annual } \\
\text { precipi- } \\
\text { tation } \\
\text { (inches) }\end{array}$} \\
\hline & & & & $\begin{array}{l}\text { Longitude } \\
\text { (decimal }\end{array}$ & $\begin{array}{l}\text { Latitude } \\
\text { gree) }\end{array}$ & \\
\hline 64 & $45-4406$ & Kachess & 2,270 & 121.2000 & 47.2667 & 52.84 \\
\hline 65 & $45-4414$ & Keechleus & 2,475 & 121.3389 & 47.3222 & 69.03 \\
\hline 66 & $45-4679$ & Lind $3 \mathrm{NE}$. & 2,630 & 118.5833 & 47.0000 & 9.18 \\
\hline 67 & $45-4971$ & Mansfield $7 \mathrm{~W}$. & 2,500 & 119.8000 & 47.8167 & 10.54 \\
\hline 68 & $45-5231$ & McNary Dam & 361 & 119.3000 & 45.9500 & 7.33 \\
\hline 69 & $45-5325$ & Methow 2 & 1,160 & 120.0000 & 48.0000 & 10.59 \\
\hline 70 & $45-5326$ & Methow 2 S. & 1,170 & 120.0167 & 48.1000 & 10.93 \\
\hline 71 & $45-5387$ & Mill Creek Dam & 1,175 & 118.2667 & 46.0833 & 17.82 \\
\hline 72 & $45-5613$ & Moses Lake & 1,070 & 119.3000 & 47.1000 & 7.46 \\
\hline 73 & 45-5659 & Mt. Adams Ranger Sta. & 1,960 & 121.5333 & 46.0000 & 43.64 \\
\hline 74 & $45-5688$ & Moxee City $10 \mathrm{E}$ & 1,550 & 120.1667 & 46.5167 & 7.79 \\
\hline 75 & $45-5832$ & Nespelem $2 \mathrm{~S}$. & 1,090 & 118.9833 & 48.1333 & 12.68 \\
\hline 76 & $45-6039$ & Odessa & 1,540 & 118.6833 & 47.3333 & 9.72 \\
\hline 77 & $45-6215$ & Othello 6 ESE. & 1,190 & 119.0500 & 46.8000 & 7.82 \\
\hline 78 & $45-6610$ & Pomeroy & 1,810 & 117.6167 & 46.4667 & 15.44 \\
\hline 79 & $45-6747$ & Priest Rapids Dam & 460 & 119.9000 & 46.6500 & 6.67 \\
\hline 80 & $45-6768$ & Prosser 4 NE. & 903 & 119.7500 & 46.2500 & 7.68 \\
\hline 81 & $45-6789$ & Pullman $2 \mathrm{NW}$. & 2,545 & 117.2000 & 46.7667 & 21.95 \\
\hline 82 & $45-6880$ & Quincy $1 \mathrm{~S}$. & 1,274 & 119.8500 & 47.2167 & 7.95 \\
\hline 83 & 45-7015 & Richland & 373 & 119.2667 & 46.3167 & 6.55 \\
\hline 84 & 45-7038 & Rimrock Reservoir & 2,730 & 121.1333 & 46.6500 & 24.72 \\
\hline 85 & 45-7059 & Ritzville 1 SSE. & 1,830 & 118.3667 & 47.1167 & 11.20 \\
\hline 86 & 45-7180 & Rosalia & 2,400 & 117.3667 & 47.2333 & 16.98 \\
\hline 87 & $45-726$ & St. John & 1,945 & 117.5833 & 47.1000 & 15.06 \\
\hline 88 & 45-7342 & Satus Pass 2 SSW. & 2,610 & 120.6500 & 45.9500 & 19.28 \\
\hline 89 & 45-7727 & Smyrna & 560 & 119.6667 & 46.8333 & 7.87 \\
\hline 90 & $45-7938$ & Spokane WSO AP & 2,356 & 117.5333 & 47.6333 & 16.61 \\
\hline 91 & 45-7956 & Sprague & 1,920 & 117.9833 & 47.3000 & 14.75 \\
\hline 92 & $45-8009$ & Stampede Pass WSCMO & 3,958 & 121.3333 & 47.2833 & 94.53 \\
\hline 93 & $45-8207$ & Sunnyside & 747 & 120.0000 & 46.3167 & 6.44 \\
\hline 94 & $45-8442$ & Tieton-Headwork S. & 2,280 & 121.0000 & 46.6711 & 20.26 \\
\hline 95 & $45-8931$ & Walla Walla WSO CI & 949 & 118.3333 & 46.0333 & 15.91 \\
\hline 96 & $45-8959$ & Wapato & 841 & 120.4167 & 46.4333 & 7.82 \\
\hline 97 & $45-9012$ & Waterville & 2,620 & 120.0667 & 47.6500 & 10.38 \\
\hline 98 & $45-9058$ & Wellpinit & 2,490 & 118.0000 & 47.9000 & 15.78 \\
\hline 99 & $45-9079$ & Wenatchee Exp. Sta. & 800 & 120.3500 & 47.4333 & 11.69 \\
\hline 100 & $45-9082$ & Wenatchee FAA AP & 1,229 & 120.2000 & 47.4000 & 10.75 \\
\hline 101 & $45-9200$ & Whitman Mission & 632 & 118.4500 & 46.0500 & 15.56 \\
\hline 102 & $45-9238$ & Wilbur & 2,160 & 118.7000 & 47.7500 & 11.14 \\
\hline 103 & $45-9465$ & Yakima WSO AP & 1,064 & 120.5333 & 46.5667 & 9.14 \\
\hline
\end{tabular}

\section{CULTURAL SETTING}

Lewis and Clark explored parts of southern Washington and northern Oregon along the Snake and Columbia Rivers in 1805; in the decade that followed, two more groups-one led by David Thompson and the other by Gabriel Frachereexplored the entire length of the Columbia River. What these early explorers found in the plateau country was a semiarid land, home to an estimated 14,000 Indians. In the 1850 's, the U.S. Government signed numerous treaties with the Indians in eastern Washington and Oregon, establishing reservations and opening up lands for settlement.
Settlements soon became communities and cities that supplied services to growing industries on the plateau, particularly the agriculture industry.

Large dams and surface-water storage reservoirs were developed on the Columbia River system beginning in 1939 to meet the demands of this expanding agricultural region. Reservoirs in the study area with storage capacities greater than 40,000 acre-ft are listed in table 3. The reservoirs on the Columbia and lower Snake Rivers alone have the potential to store more than 43 million acre-ft of water. The stored water is used primarily for hydroelectric power production, irrigation, navigation, and flood control. 


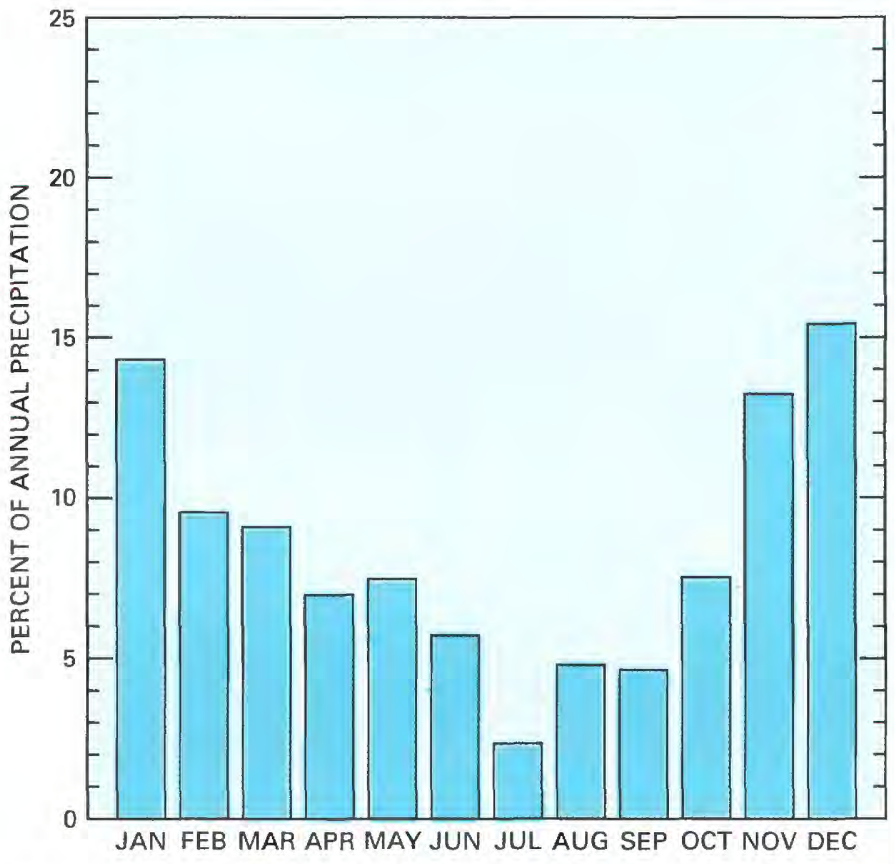

FIGURE 3.-Mean monthly distribution of precipitation at 103 weather stations, 1956-77 (from Nelson, 1991).

\section{WATER-RESOURCE AND ECONOMIC DEVELOPMENT}

The cultural and economic development of the Columbia Plateau has depended heavily on the availability of water and on the ability to store and redistribute water from the Columbia River and its major tributaries. Irrigation began as early as the 1840 's in the Yakima River valley, where settlers experimented with a wide variety of crops. Transportation was greatly improved in the late 1800's, when three railroad systems were built across the Columbia Plateau. Large land-grant acreages given to the railroads served to attract settlers, encourage exportation of crops, and promote investments in irrigation and in agriculture-related businesses. Numerous towns sprang up, some almost overnight. In the early 1900's, the lumber and agricultural industries grew steadily. Small-grain production on dryland farms and dairy and poultry farming were especially profitable because these enterprises did not need large quantities of water.

The region's dry summer climate forced the early settlers to develop water supplies for irrigation wherever possible. Most early attempts to form and finance irrigation districts and water-user associations failed. By the 1930's, economic growth was relatively low because of the 1929 depression and severe droughts that occurred after 1912 and again in the 1930's. Those who survived these hardships lived along surface-water bodies or in areas where ground water was available at shallow depths. A notable exception to this pattern of hardship was the Yakima River basin, where reservoirs, diversion dams, and canals were constructed during the period 1892-1933. These water projects ensured that irrigation water was available, and thus

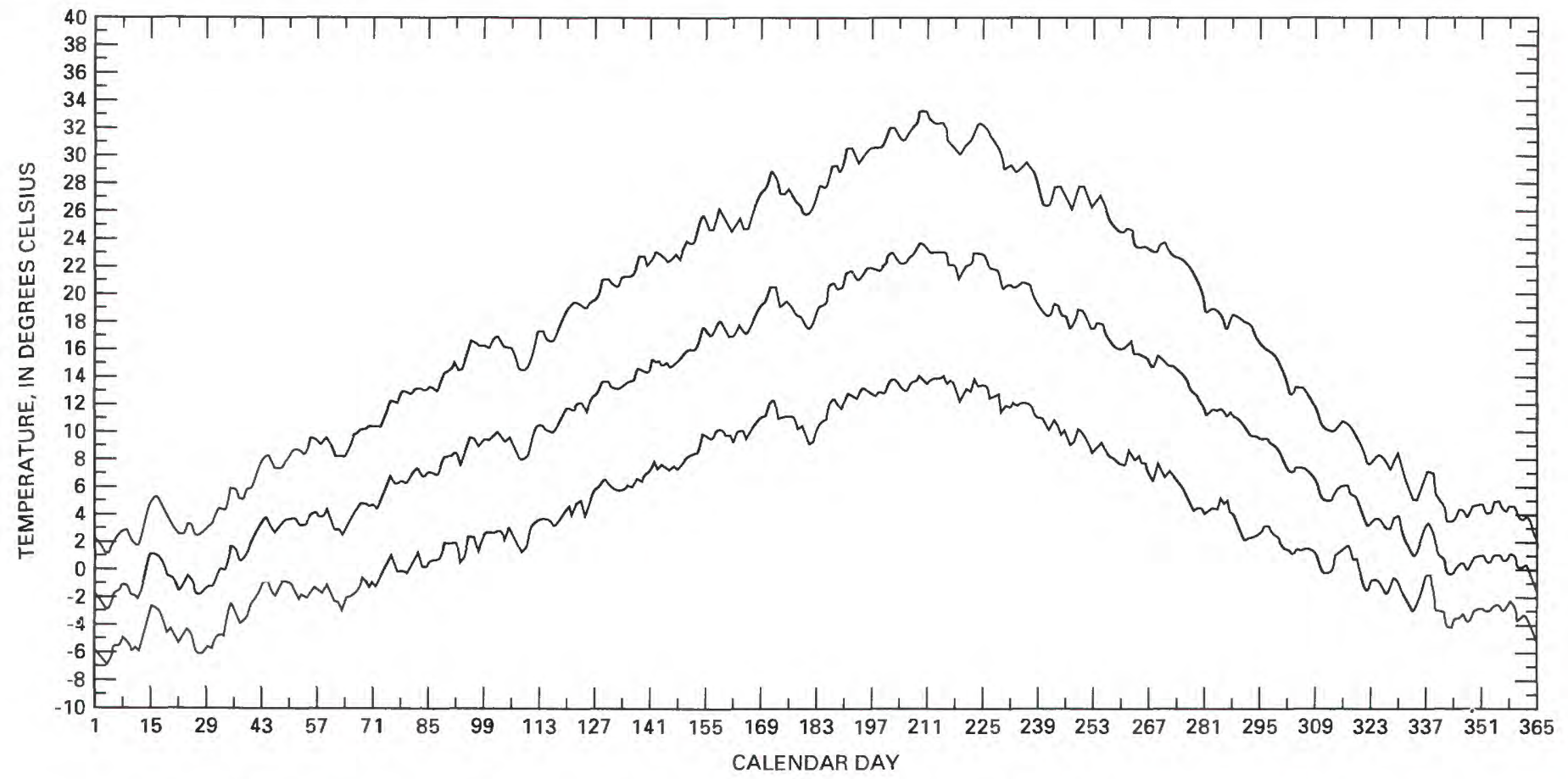

FIgURE 4.-Mean minimum, mean, and maximum daily air temperatures at 89 weather stations, $1956-77$. 
TABLE 2.-Mean air temperature data from selected weather stations, 1956-77

\begin{tabular}{|c|c|c|c|c|c|c|c|}
\hline \multirow[b]{2}{*}{ Station } & \multicolumn{3}{|c|}{$\begin{array}{l}\text { Mean air temperature, } \\
\text { in degrees Celsius }\end{array}$} & \multirow[b]{2}{*}{ Station } & \multicolumn{3}{|c|}{$\begin{array}{l}\text { Mean air temperature, } \\
\text { in degrees Celsius }\end{array}$} \\
\hline & Minimum & Maximum & Average & & Minimum & Maximum & Average \\
\hline Antelope & 2.84 & 16.69 & 9.77 & Hartline & 2.58 & 15.85 & 9.22 \\
\hline Arlington & 5.99 & 19.03 & 12.51 & Hatton 9 ESE. & 3.08 & 17.36 & 10.22 \\
\hline Boardman & 5.27 & 18.46 & 11.86 & Ice Harbor Dam & 5.67 & 18.71 & 12.18 \\
\hline Bonneville Dam & 6.65 & 15.86 & 11.26 & Kennewick & 5.80 & 18.82 & 12.31 \\
\hline Condon & 2.19 & 15.43 & 8.81 & La Crosse & 2.95 & 16.73 & 9.84 \\
\hline Cove & 1.02 & 15.61 & 8.32 & Lake Cle Elum & 1.43 & 12.51 & 6.97 \\
\hline Dufur & 2.07 & 17.29 & 9.68 & Kachess & 1.41 & 12.29 & 6.85 \\
\hline Elgin & .74 & 16.68 & 8.71 & Keechleus & .58 & 10.86 & 5.72 \\
\hline Enterprise & -1.53 & 14.47 & 6.47 & Lind 3 NE. & 2.87 & 17.18 & 10.03 \\
\hline Fossil & 1.11 & 16.66 & 8.88 & Mansfield $7 \mathrm{~W}$. & 3.53 & 15.57 & 9.55 \\
\hline Government Camp & .86 & 10.32 & 5.59 & McNary Dam & 6.57 & 18.21 & 12.39 \\
\hline Heppner & 3.67 & 17.12 & 10.39 & Methow 2 & 2.95 & 15.87 & 9.41 \\
\hline Hermiston $2 \mathrm{~S}$. & 4.65 & 18.54 & 11.59 & Moses Lake & 2.83 & 16.48 & 9.66 \\
\hline Hood River Exp. Sta. & 4.42 & 16.14 & 10.28 & Mt. Adams Ranger Sta. & 1.89 & 15.17 & 8.53 \\
\hline Kent & 2.64 & 15.29 & 8.97 & Moxee City $10 \mathrm{E}$. & 2.23 & 16.12 & 9.18 \\
\hline La Grande & 1.86 & 16.00 & 8.93 & Nespelem $2 \mathrm{~S}$. & 1.25 & 16.20 & 8.73 \\
\hline Mikkalo 6 W. & 4.86 & 17.12 & 10.99 & Odessa & 2.14 & 17.27 & 9.71 \\
\hline Milton Freewater & 5.98 & 18.45 & 12.22 & Othello 6 ESE. & 3.64 & 16.97 & 10.31 \\
\hline Minam 7 NE. & -2.62 & 13.74 & 5.56 & Pomeroy & 3.84 & 17.08 & 10.46 \\
\hline Monument 2 & 1.44 & 17.98 & 9.72 & Priest Rapids Dam & 6.90 & 18.66 & 12.78 \\
\hline Moro & 3.29 & 15.46 & 9.38 & Prosser 4 NE. & 3.63 & 17.50 & 10.57 \\
\hline Parkdale 2 SSE. & 3.87 & 14.53 & 9.20 & Pullman 2 NW. & 2.64 & 14.18 & 8.41 \\
\hline Pendleton Exp. Sta. & 3.17 & 17.63 & 10.40 & Quincy $1 \mathrm{~S}$. & 2.88 & 16.74 & 9.81 \\
\hline Pendleton WSO AP & 5.61 & 17.61 & 11.61 & Richland & 5.78 & 19.40 & 12.59 \\
\hline Pilot Rock $1 \mathrm{SE}$. & 3.11 & 17.99 & 10.55 & Rimrock Reservoir & .35 & 13.34 & 6.85 \\
\hline The Dalles & 6.06 & 18.37 & 12.21 & Ritzville 1 SSE. & 2.27 & 15.97 & 9.12 \\
\hline Ukiak & -1.80 & 15.18 & 6.69 & Rosalia & 2.27 & 14.31 & 8.29 \\
\hline Union Exp. Sta. & 2.06 & 15.38 & 8.72 & St. John & 2.34 & 15.77 & 9.06 \\
\hline Walla Walla 13 ESE. & 2.14 & 14.91 & 8.52 & Satus Pass 2 SSW. & 2.46 & 15.27 & 8.87 \\
\hline Appleton & 2.53 & 14.08 & 8.31 & Smyrna & 4.41 & 18.43 & 11.42 \\
\hline Bickleton & 2.60 & 14.33 & 8.47 & Spokane WSO AP & 2.91 & 14.03 & 8.47 \\
\hline Bumping Lake & -.38 & 12.32 & 5.97 & Sprague & 1.64 & 15.86 & 8.75 \\
\hline Chelan & 4.57 & 15.52 & 10.04 & Stampede Pass WSCMO & .85 & 7.41 & 4.13 \\
\hline Chief Joseph Dam & 3.78 & 16.34 & 10.07 & Sunnyside & 3.87 & 18.51 & 11.18 \\
\hline Cle Elum & 1.37 & 14.32 & 7.84 & Tieton-Headwork S. & .84 & 13.72 & 7.28 \\
\hline Colfax $1 \mathrm{NW}$. & 2.45 & 15.55 & 9.00 & Walla Walla WSO CI & 7.11 & 17.60 & 12.36 \\
\hline Connell $1 \mathrm{~W}$. & 3.57 & 17.91 & 10.73 & Wapato & 3.73 & 17.28 & 10.51 \\
\hline Coulee Dam $1 \mathrm{sW}$. & 4.29 & 15.37 & 9.83 & Waterville & 3.46 & 15.42 & 9.43 \\
\hline Dallesport FAA AP & 5.99 & 17.96 & 11.98 & Wellpinit & 2.36 & 14.69 & 8.53 \\
\hline Davenport & 1.56 & 14.45 & 8.01 & Wenatchee Exp. Sta. & 3.38 & 15.89 & 9.64 \\
\hline Dayton 1 WSW. & 4.21 & 16.99 & 10.60 & Wenatchee FAA AP & 3.75 & 15.84 & 9.80 \\
\hline Ellensburg & 2.12 & 15.51 & 8.82 & Whitman Mission & 5.46 & 17.78 & 11.62 \\
\hline Eltopia 8 WSW. & 4.07 & 17.57 & 10.82 & Wilbur & 2.48 & 15.59 & 9.04 \\
\hline Ephrata FAA AP & 5.01 & 16.57 & 10.79 & Yakima WSO AP & 2.47 & 16.18 & 9.32 \\
\hline Goldendale 2 & 3.57 & 16.18 & 9.87 & & & & \\
\hline
\end{tabular}

economic growth in this part of the plateau has been steady.

The start of the Columbia Basin Irrigation Project (CBIP) (see fig. 1) in 1933 and construction of the Hanford Nuclear Reservation (located in northern Benton County, Wash.) in the 1940's brought about a large influx of construction workers and associated service industries. Water from the Grand Coulee Equalization Reservoir became available for irrigation in 1952, and by 1972 more than 0.5 million acres in Franklin, southern Grant, and eastern Adams Counties were being irrigated by this project. More than 60 types of crops were being produced commercially, including fruits, vegetables, and seeds. Major crops included hay and seed, sugar beets, corn, potatoes, and wheat. Currently (1980's), about 1.3 million acres of croplands are irrigated with surface water.

A rapid and intensive expansion of deep-well irrigation practices took place in areas not served by the CBIP starting around 1950, although earlier ground-water development had occurred in areas scattered throughout the plateau. Some of the most intensive early development of ground water was in the Yakima River basin and near Walla Walla, Wash. As ground-water pumpage increased, water 


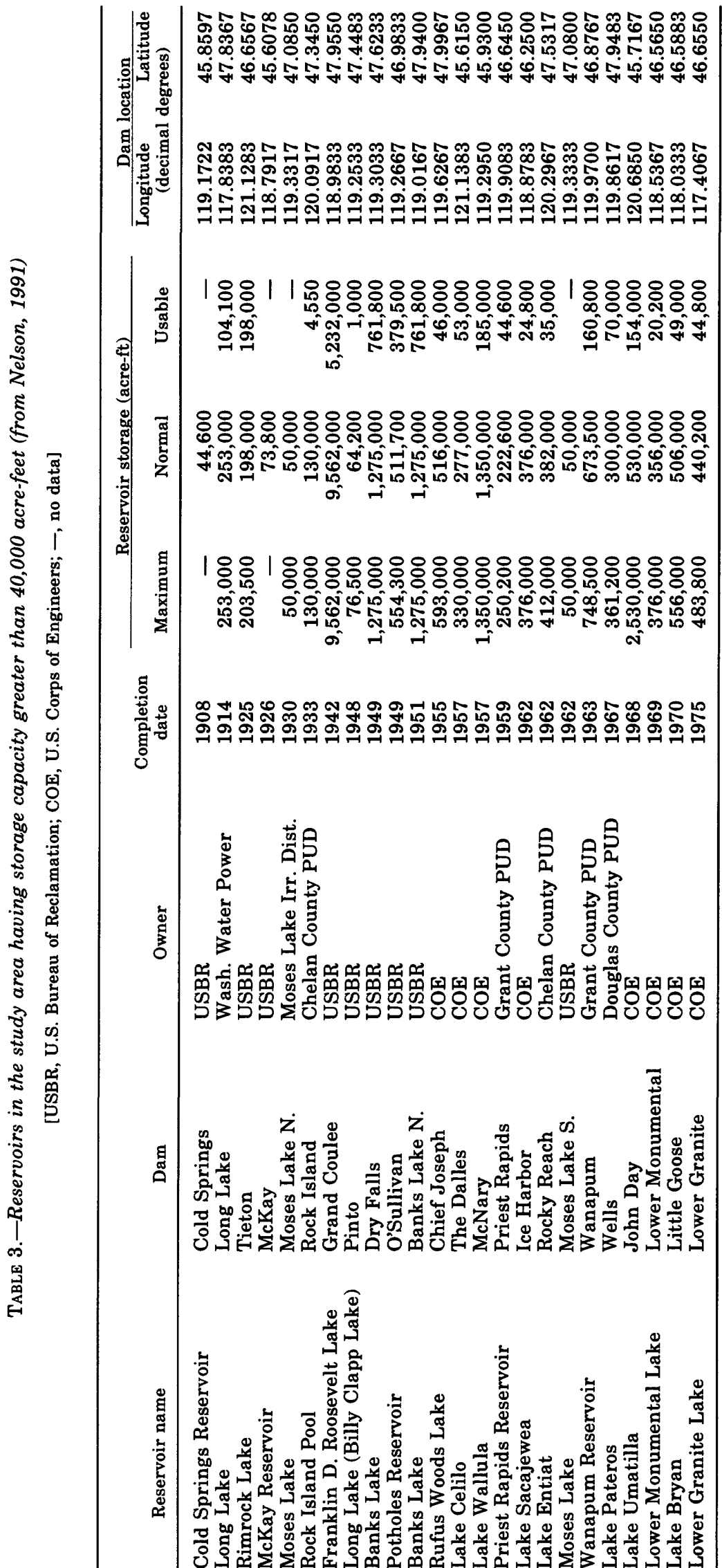


levels in the pumped areas declined. In central Washington, declines over the past 25 years locally have exceeded $150 \mathrm{ft}$ (Cline, 1984). An estimated 1.5 million acres of land in Douglas, Lincoln, Grant, Adams, Franklin, Garfield, and Whitman Counties could be cropped profitably if water supplies were available (Pacific Northwest River Basins Commission, 1971). Only a relatively small part of the available land in this so-called dry belt has been put into irrigation at present (1987).

Some parts of the Columbia Plateau, where ground water is the principal water source, receive sufficient precipitation to support a dryland farming economy. In areas where the soils are not suitable for croplands, the predominant economic activity is sheep and cattle ranching.

The number of farms with irrigated lands and the average farm size for the period 1949 to 1982 are shown in figure 5. Overall, there has been a steady increase in irrigated acreage throughout the Columbia Plateau (see fig. 35 in "Ground-Water Development" section) and a trend toward fewer but larger farms (fig. 5) (U.S. Department of Commerce, 1982). There has been a change in these trends over the last decade, reflecting financial hardships that are seriously affecting the owners of intermediate-sized farms. Large-farm operators are better able to survive difficult financial periods, and owners of small farms often work outside jobs to supplement farm income.

Population trends of the Columbia Plateau (fig. 6) correspond to changes in economic conditions. Population increases from 1900 to 1910 reflect the influx of settlers attracted by the availability of lands made accessible by the newly completed railroads. Population leveled out in response to slower

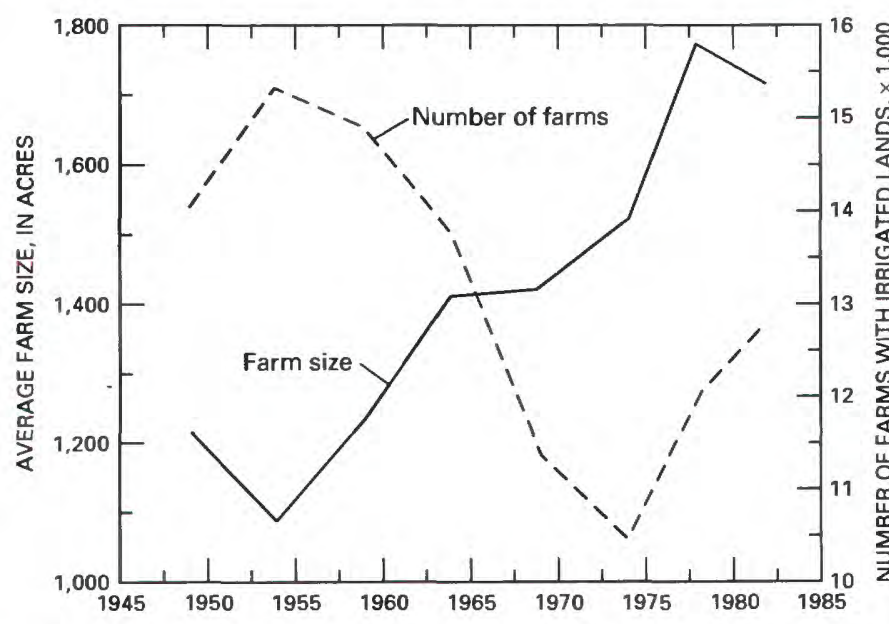

FIGURE 5.-Number of farms with irrigated lands and average farm size, 1949-82 (U.S. Department of Commerce, 1982).

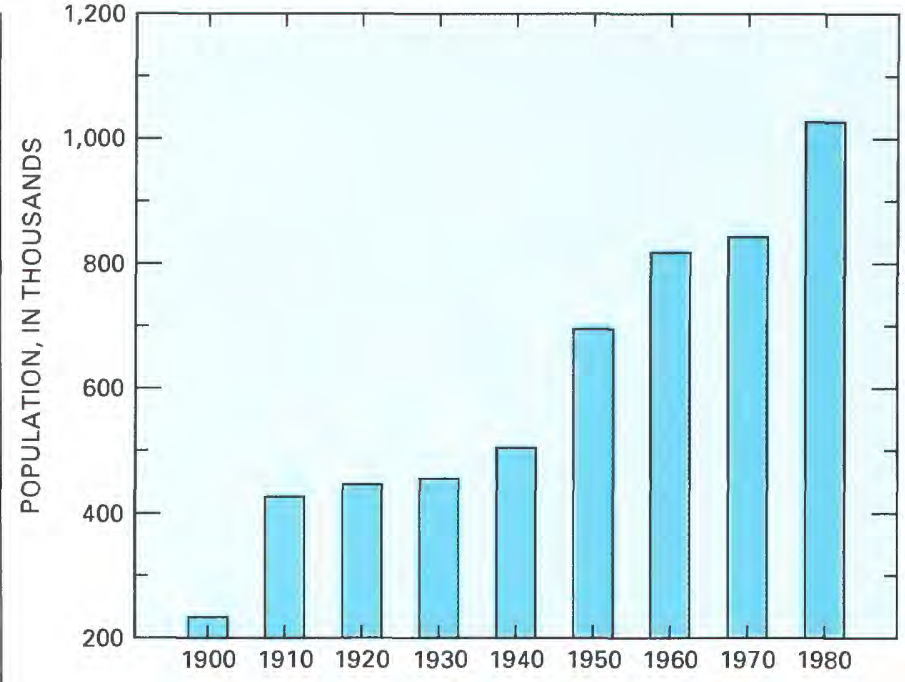

Figure 6.-Population of the Columbia Plateau area, 1900-80.

economic growth between 1910 and 1930. Construction of the CBIP, water-power projects, and the Hanford Nuclear Reservation contributed to the steep rise in population in the 1940's. Irrigation water made available by CBIP and through drilling of deep wells in the basalts spurred growth from the 1950's through the 1970's. The area had a slow rate of increase in population from 1960 to 1970, although there was a net decrease in population of approximately 15,000 people in Adams, Grant, and Lincoln Counties in Washington. During this period, Larson Air Force Base at Moses Lake, Wash., was closed, Titan Missile Base construction in eastern Washington was terminated, and construction of irrigation facilities in Washington decreased.

\section{HYDROGEOLOGIC FRAMEWORK}

An understanding of the geologic framework of the Columbia Plateau aquifer system has become increasingly important in recent years, not only because of questions concerning ground-water availability and quality, but also because of proposals to use the U.S. Department of Energy's Hanford Nuclear Reservation as a potential highlevel nuclear-waste repository site. The information on rock types-their distribution, thickness, hydrologic properties, and structural characteristics-is important to these issues.

\section{GEOLOGY}

The Columbia Plateau regional aquifer system defined in this report includes, from youngest to 


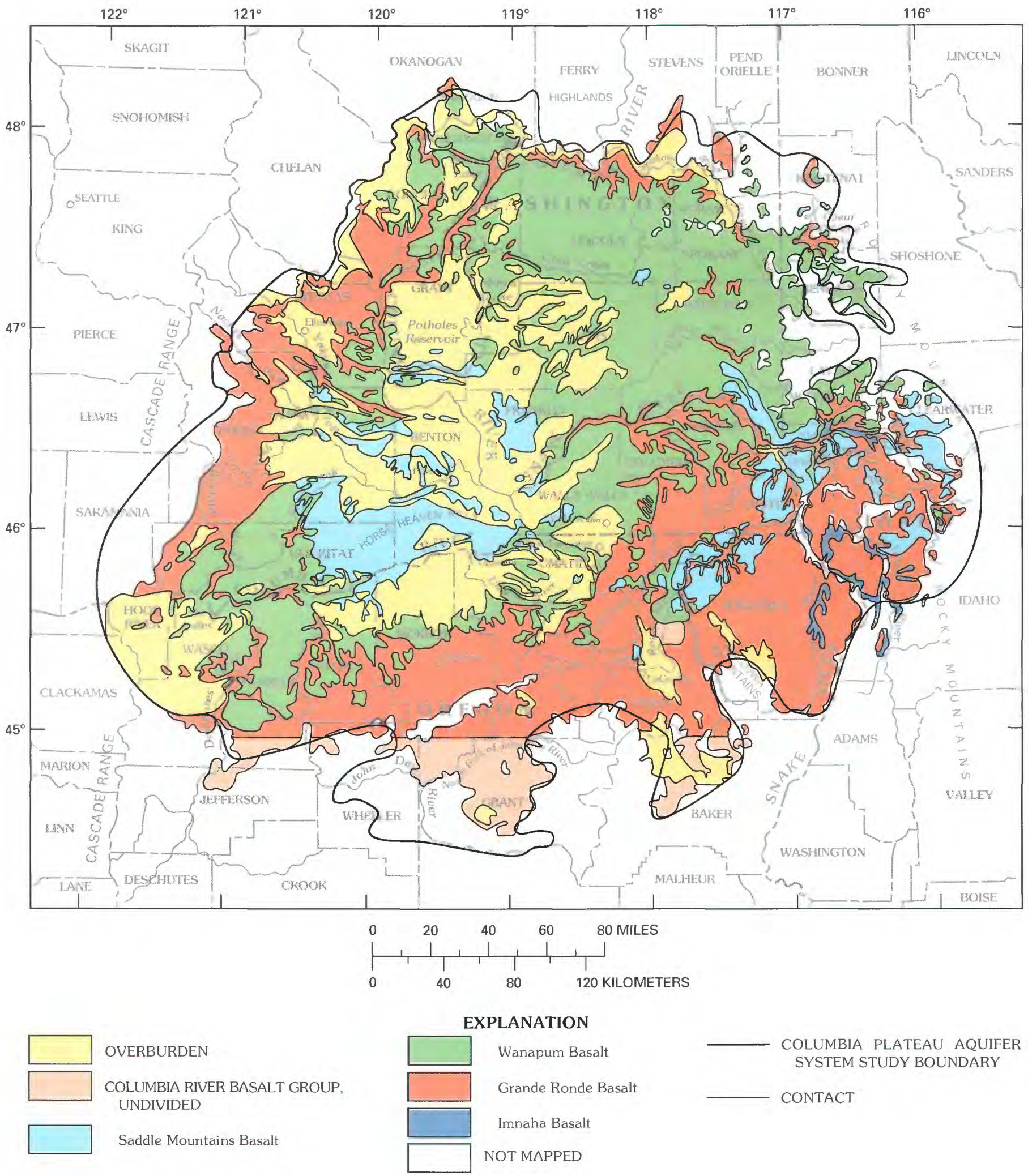

\section{$\boldsymbol{A}$}

Figure 7.-Generalized surficial geology $(A)$ and stratigraphic chart $(B)$ for the Columbia Plateau. (Modified from Drost and others, 1990.) Magnetostratigraphic units: $N$, normal polarity; $R$, reverse polarity; $T$, transition polarity; units numbered sequentially from oldest to youngest. 
oldest, (1) Holocene to Miocene overburden, a collective term used in this study for all materials overlying the Columbia River Basalt Group, (2) minor sedimentary units of Miocene age interlayered with the basalts, and (3) a large thickness of Miocene basalt belonging to the Columbia River Basalt Group. The discussions that follow summarize the geologic characteristics and are based on previous work completed during this project by Drost and Whiteman (1986), Gonthier (1990), and Drost and others (1990). A generalized surficial geology map and stratigraphic chart for the plateau is presented in figure 7. Pre-Columbia River Basalt Group rocks underlie the plateau and are presumed to consist primarily of less permeable rocks that form the lower hydrogeologic boundary to the aquifer system. These are sedimentary, igne- ous, and metamorphic rocks that range in age from Precambrian through early Tertiary.

Basaltic lavas that make up the bulk of the Columbia Plateau aquifer system were extruded during the Miocene Epoch between 17 and 6 million years ago from north-northwest-trending fissures as much as $90 \mathrm{mi}$ long chiefly in northeastern Oregon and southeastern Washington (Hooper, 1982). Flows from these vents covered about 63,200 $\mathrm{mi}^{2}$ of eastern Washington, northern Oregon, and western Idaho to an average total thickness of $3,300 \mathrm{ft}$. About 95 percent of the basalt was extruded in episodic eruptions during the first 3 million years of that interval. An estimate of the duration and flow rate of a single large eruption of the basalt (Swanson and others, 1975) suggests that a fissure about $90 \mathrm{mi}$ long spewed fluid lava

\begin{tabular}{|c|c|c|c|c|c|}
\hline \multicolumn{6}{|c|}{ GEOLOGIC FRAMEWORK } \\
\hline \multicolumn{5}{|c|}{ BASALT STRATIGRAPHY } & SEDIMENT STRATIGRAPHY \\
\hline & & & & & $\begin{array}{l}\text { Sediments of Miocene through } \\
\text { Holocene age (glaciofluvial, fluvial, } \\
\text { lacustrine, eolian, and ash fall } \\
\text { materials). Locally includes sediments } \\
\text { of the Palouse, Latah, Ringold, and } \\
\text { Ellensburg Formations, and the Dalles } \\
\text { Group (Farooqui and others, 1981). }\end{array}$ \\
\hline \multirow{6}{*}{ 岂 } & \multirow{5}{*}{ 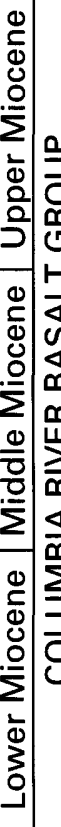 } & 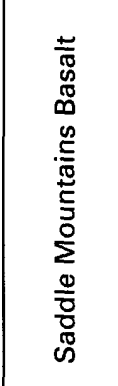 & \multicolumn{2}{|l|}{$\begin{array}{l}\text { Lower Monumental Member } \\
\text { Ice Harbor Member } \\
\text { Buford Member } \\
\text { Elephant Mountain Member } \\
\text { Pomona Member } \\
\text { Esquatzel Member } \\
\text { Weissenfels Ridge Member } \\
\text { Asotin Member } \\
\text { Wilbur Creek Member } \\
\text { Umatilla Member }\end{array}$} & \\
\hline & & \multirow{2}{*}{ 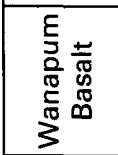 } & \multirow{2}{*}{\multicolumn{2}{|c|}{$\begin{array}{l}\text { Priest Rapids Member } \\
\text { Roza Member } \\
\text { Frenchman Springs Member } \\
\text { Eckler Mountain Member }\end{array}$}} & Saddle Mountains-Wanapum Interbed \\
\hline & & & & & \\
\hline & & $>\quad s$ & & \multirow{3}{*}{\begin{tabular}{l|}
$N_{2}$ \\
$R_{2}$ \\
$N_{1}$ \\
$R_{1}$ \\
$T$ \\
$N_{0}$ \\
$R_{0}$
\end{tabular}} & Wanapum-Grande Ronde Interbed \\
\hline & & $\begin{array}{c}\text { Ronde } \\
\text { Basalt } \\
\text { Picture } \\
\text { Gorge } \\
\text { Basalt } \\
\end{array}$ & 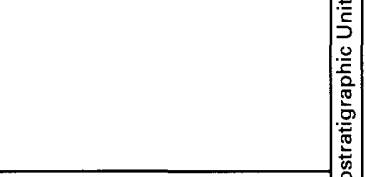 & & \\
\hline & & $\begin{array}{c}\text { Imnaha } \\
\text { Basalt }\end{array}$ & 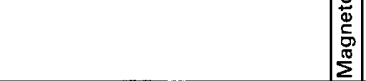 & & \\
\hline 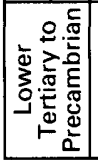 & & \multicolumn{4}{|c|}{ Basement rocks (pre-Columbia River Basalt Group) } \\
\hline
\end{tabular}


at a rate of $0.24 \mathrm{mi}^{3}$ from each $0.6 \mathrm{mi}$ of vent over a duration of about 7 days. The basalt in that eruption flowed about $186 \mathrm{mi}$ west and covered a vast area of the plateau. It is assumed that many of the flows in the Columbia River Basalt Group were of similar or larger magnitude because some flows extend to the Pacific Ocean, more than 340 mi from their known vents (Hooper, 1982).

Prebasalt topography in the vent areas had considerable relief; early lava flows, therefore, filled narrow prebasalt valleys and gradually smoothed out the Miocene landscape. Later flows spread in thin sheets across a flat, west-sloping paleosurface having a few minor warps. It is likely that water was present on this paleosurface, and the interaction between the water and overriding molten lava caused rapid chilling and shattering of the basalt, pillow lava complexes, and structural irregularities from steam explosions within an individual lava flow.

Warping and folding of the plateau increased late in the eruptive cycle, forming the Frenchman Hills, Horse Heaven Hills, The Dalles-Umatilla syncline, Blue Mountains uplift, and numerous other geologic structures discussed later in this report. A more detailed account of the structural evolution of the Columbia Plateau has been presented by Barrash and others (1983). Because these tectonic activities were mostly in the western and southern plateau, late basalt flows tended to be confined to the central part of the plateau and were restricted to narrow canyons near the plateau margin. These younger flows have been buried under sediments in many areas and are usually more continuous areally than older basalt flows, which have been thinned by erosion, cut by streams, and affected by folding, uplift, and faulting.

Sedimentary interbeds are more common in the younger basalt and were deposited in shallow lake basins on the warped basalt surface between eruptive phases. Eruption of basalt ceased some 6 million years ago, but folding, erosion, and deposition of sediments has continued. The Cascade Range has been the principal source of large quantities of sediments and volcaniclastics, which have been transported by air and water and deposited in adjacent areas, reflecting the greater thicknesses of overburden seen in the western part of the plateau. Erosion is now the dominant process affecting the Columbia Plateau.

\section{OVERBURDEN}

In this report, overburden is the term used to describe a composite unit consisting of all rock materials $50 \mathrm{ft}$ or more in thickness that overlie the Columbia River Basalt Group and are important sources of ground water. The thickness of the overburden ranges from 50 to more than $2,000 \mathrm{ft}$, with the thickest deposits occurring in structural basins and in areas adjacent to the Cascade Range (fig. 8). The overburden exceeds a thickness of $2,000 \mathrm{ft}$ in the Grande Ronde Valley near La Grande, Oreg., $1,200 \mathrm{ft}$ in the Ahtanum Valley near Yakima, Wash., and 1,000 ft in the Toppenish Valley near Toppenish, Wash.

The overburden includes consolidated to unconsolidated deposits of fluvial, lacustrine, and volcanic origin ranging from Miocene to Holocene age. The sediments and sedimentary rocks are lithologically diverse, ranging from clay to gravels and shale to conglomerate from many different formations across the plateau; however, in any one area, only a few formations may be present. In Oregon, several major formations within the overburden have been assigned to the Dalles Group by Farooqui and others (1981), and this term is used in this report. Other major formations composing the overburden are the Ellensburg, Latah, Ringold, and Palouse. Although these formations were not mapped or studied individually during this study, they are described briefly below.

Sedimentary deposits belonging to the Ellensburg Formation of Miocene age are interbedded with the basalt and also overlie it in the western and central part of the plateau. The deposits that overlie the basalt are thickest and coarsest along the west edge of the plateau and become finer toward the east, reflecting a Cascade Range source. They consist of weakly lithified fluvial sand and gravel with some lahars and sand, silt, and clay. They occur chiefly in the Yakima River valley and are folded with the underlying Columbia River Basalt Group (Myers and Price, 1979). In the Yakima River valley, the Ellensburg Formation reaches thicknesses of several hundreds of feet.

In the northeastern part of the plateau and within the Spokane River drainage, beds of the Latah Formation of Miocene age are interbedded with and overlie the basalt. These sediments consist mostly of finely laminated siltstone with some claystone, the composition of which reflects the pre-Columbia River Basalt Group granitic and metamorphic basement rocks of the region. Although the Latah Formation is as much as $1,500 \mathrm{ft}$ thick in places, it is generally much thinner and is found mostly beyond the edges of the basalt plateau.

In the structural basins near Pasco, Quincy, and Walla Walla, Wash., the sediments overlying the 


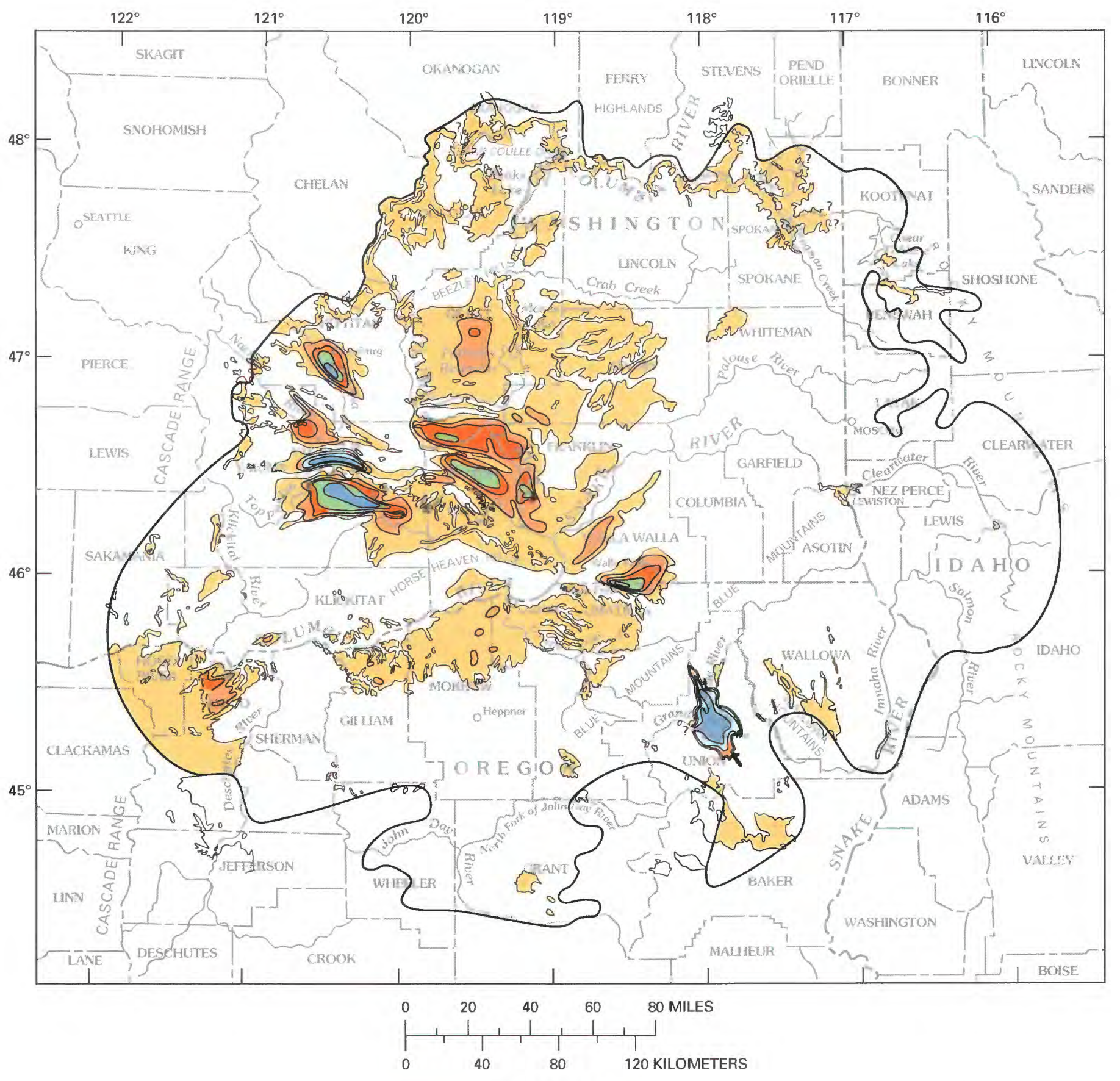

EXPLANATION

OVERBURDEN THICKNESS, IN FEET

$50-200$

$200-400$

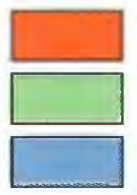

$400-800$
COLUMBIA PLATEAU AQUIFER SYSTEM STUDY BOUNDARY

APPROXIMATE BOUNDARY OF OVERBURDEN-Dashed where inferred; queried where uncertain

Figure 8.-Extent and thickness of overburden where its thickness is generally 50 feet or more. (Modified from Drost and others, 1990.) 
basalt are part of the Ringold Formation. The Ringold Formation is of Pliocene age and includes sediments of both fluvial and lacustrine origin. It is at least $500 \mathrm{ft}$ thick in these basins and consists predominantly of fine sand and silt, but alsc includes a gravel and conglomerate facies at one locality (Myers and Price, 1979).

Structural basins on the plateau margin south of the Columbia River in Oregon contain sediments that overlie the basalt and are folded with it; these have been assigned to the Dalles Group of Miocene and Pliocene age by Farooqui and others (1981). The sediments consist of coarse- to fine-grained fluvial deposits, lahars, and volcaniclastic materials that reflect source areas in the nearby uplands on the plateau margin. In The Dalles area (fig. 8), these units reach thicknesses of several hundreds of feet and are deeply eroded.

The Grande Ronde Valley in northeastern Oregon (fig. 8) is a major graben, filled with more than 2,000 $\mathrm{ft}$ of fluviolacustrine deposits, interfingering alluvialfan deposits, and alluvial deposits. Materials in these deposits are primarily fine-grained siltstone and claystone at depth, whereas the upper few hundred feet or less contain some sand and gravel.

The Cordilleran ice sheet that covered the northern and northwestern part of the plateau left extensive deposits of till, stratified drift, and ice contact materials, especially in that area. Alpine glaciers from the Cascade Range and the Wallowa Mountains also reached the plateau margin and left deposits.

Catastrophic flooding of the Columbia Plateau took place during the late Pleistocene when ice dams in western Montana and northern Idaho were breached, allowing enormous volumes of water to flood what is now eastern and central Washington and to rush along the lower Snake River and the lower Columbia River (Bretz, 1923a, b). Deposits formed during the flood(s) were of two main types: (1) a "flood-gravel facies" deposited by high-energy flood currents in and along scabland channels, in depositional basins, and in the Columbia River east of The Dalles, and (2) a "slack-water facies" formed in peripheral areas of basins in the central part of the plateau. Flood-gravel deposits consist of poorly sorted, clast-supported, open-work gravels deposited as gravel bars; also present are gravel and intermixed sand and gravels. Slack-water deposits are interbedded silt and sand and minor gravel and are known as the Touchet Beds (Flint, 1938).

Eolian deposits of fine loess of Pleistocene age cover much of the plateau up to altitudes between 2,700 and $3,200 \mathrm{ft}$ and reach thicknesses of as much as $250 \mathrm{ft}$, but generally are much thinner. The thickest deposits are found in the area surrounding the Palouse River in the eastern part of the study area and are part of the Palouse Formation. At least four different ages of loess deposits are present on the Columbia Plateau. The loess deposits are not shown on figure 8 because they are generally unsaturated.

Unconsolidated alluvial deposits of Quaternary age occur along most major streams and consist of gravel, sand, silt, and clay. Dune-sand deposits of Quaternary age, consisting predominantly of fineto medium-grained windblown sand, are found in Oregon and in central Grant County in Washington.

\section{COLUMBIA RIVER BASALT GROUP}

The thickest, most extensive, and hydrologically most important geologic unit in the Columbia Plateau aquifer system is the Columbia River Basalt Group of Miocene age, a unit that has been subdivided into five formations and numerous members (fig. $7 B$ ). The five formations, from oldest to youngest, are the Imnaha Basalt, Picture Gorge Basalt, Grande Ronde Basalt, Wanapum Basalt, and Saddle Mountains Basalt. The Imnaha Basalt and the Picture Gorge Basalt crop out chiefly east and south of the study area.

The Imnaha Basalt is found in northeastern Oregon and adjacent Washington and Idaho, where it is exposed chiefly in the valleys of the Imnaha, Snake, Salmon, and Clearwater Rivers (fig. 7A). The Imnaha Basalt consists mostly of phyric flows with coarse-grained plagioclase. It unconformably overlies pre-Tertiary metamorphic and plutonic rocks and was extruded on a rugged erosional surface with more than $1,600 \mathrm{ft}$ of local relief (Swanson and others, 1979a). About 1,600 ft of basalt is exposed at the type locality, where the base of the formation is not exposed.

In this study, the Picture Gorge Basalt has not been distinguished from the rest of the Columbia River Basalt Group and is included within either the Grande Ronde Basalt or the undivided category in figure $7 A$. The Picture Gorge Basalt is exposed only in north-central Oregon, mostly within the John Day Basin south of the Blue Mountains uplift, where it is locally interlayered with Grande Ronde Basalt and is in part coeval with it. The Picture Gorge Basalt reaches a maximum known thickness of $2,600 \mathrm{ft}$ and consists of mostly finegrained plagioclase in phyric and some aphyric flows. Source vents for the Picture Gorge Basalt are east of Kimberly in the John Day Basin (fig. 
7A). The Imnaha and Picture Gorge Basalts are not considered important units in the aquifer system because of their limited extent and their occurrence at the edges of the study area.

The principal geologic formations in the Columbia Plateau aquifer system are part of the Yakima Basalt Subgroup of the Columbia River Basalt Group. These formations, from oldest to youngest, are the Grande Ronde, Wanapum, and Saddle Mountains Basalts. The generalized occurrence of these three formations is shown in figure $7 A$, and the accompanying stratigraphic chart (fig. $7 B$ ) lists the members within each formation. Differentiating these members by extent and thickness was not within the scope of the present study but will be included in the following discussion. Two generalized geologic sections across the Columbia Plateau indicate the relative extents and thicknesses of the overburden and the three principal basalt formations (fig. 9).

The Grande Ronde Basalt underlies most of the plateau and pinches out at its margin. It is the most extensive of the three major formations, constituting 85 to 88 percent of the total volume of the Columbia River Basalt Group (Reidel, 1982; Tolan and others, 1987). The Grande Ronde Basalt probably consists of as many as 131 individual flows (Tolan and others, 1987). It is conformable with the Imnaha and Picture Gorge Basalts where they are in contact. Swanson and others $(1979 b, c, 1981)$ subdivided the Grande Ronde Basalt, using observed magnetic properties ( $N$, normal magnetic polarity; $\mathrm{R}$, reversed; and $\mathrm{T}$, transitional), into four distinct magnetostratigraphic units because of the general absence of other distinguishing lithologies or chemical differences (fig. 7). The magnetostratigraphic units were named by Swanson and others (1979c) as $R_{1}, N_{1}, R_{2}$, and $N_{2}$, where the polarity and the polarity intervals were numbered sequentially from oldest to youngest, beginning with the top of the Imnaha Basalt (fig. $7 B$ ). However, this method could not be used where the Grande Ronde was covered. Most Grande Ronde flows are fine-grained aphyric rocks with microphenocrysts of plagioclase and clinopyroxene. Olivine is generally present as a groundmass constituent and makes up less than 0.5 percent of the flow volume. Few drill holes on the plateau penetrate the total basalt thickness; thus, little is known about the complete thickness of the Grande Ronde Basalt except at the edges of the plateau, where the basalts are relatively thin and pinch out against older rocks. The combined thickness of the Grande Ronde Basalt and older basalts is shown in figure 10. In most places, the Grande Ronde Basalt constitutes the entire thickness of the basalt. Locally, the Picture Gorge, Imnaha, or basalts older than the Columbia River Basalt Group may be included in the thicknesses shown. In the center of the plateau, the total thickness of pre-Wanapum basalts probably exceeds $10,000 \mathrm{ft}$. Sedimentary interbeds within the Grande Ronde Basalt are rare, generally only a few feet thick and of limited lateral extent. Where present, they vary in grain size from clay to gravel. Interbeds apparently are more common near the plateau margin.

The altitude of the top of the Grande Ronde Basalt has been contoured in areas where it is overlain by younger basalt or overburden materials (fig. 11). The top of this formation is marked by a zone of weathering and (or) a sedimentary interbed separating it from the overlying Wanapum or Saddle Mountains Basalts. Over most of the area, this sedimentary interbed is the Vantage Member of the Ellensburg Formation; however, in the northeastern part of the plateau, the sedimentary interbed in the same stratigraphic position is assigned to the Latah Formation (Swanson and others, 1979c). To avoid nomenclature problems of this type during this study, the interbeds are named on the basis of their typical stratigraphic position within the basalt-for example, the Wanapum-Grande Ronde interbed. The WanapumGrande Ronde interbed is most extensive and thickest in the northern part of the plateau (fig. 12), where its thickness ranges from 0 to $100 \mathrm{ft}$ locally but averages about $25 \mathrm{ft}$. It consists chiefly of claystone and siltstone, with minor sand and gravel and sandstone beds. It is thinner to the south, and in the central plateau little is known about its extent. A thin saprolite commonly marks the interval in areas where the interbed is missing. In the absence of either the interbed or the saprolite, the contact between the Grande Ronde Basalt and overlying Wanapum Basalt is difficult to identify without information on minerals.

The Wanapum Basalt overlies the Grande Ronde Basalt and is the second most voluminous and extensive basalt formation in the Columbia River Basalt Group. It composes about 6 percent of the total volume of the basalts. Along part of the northeastern and eastern edges of the plateau, the Wanapum Basalt overlies the prebasalt rock. The Wanapum Basalt includes as many as 33 separate basalt flows (Tolan and others, 1987) consisting of medium-grained, olivine-bearing, slightly to moderately plagioclase-phyric basalt relatively high in iron and titanium oxides. It has been subdivided 


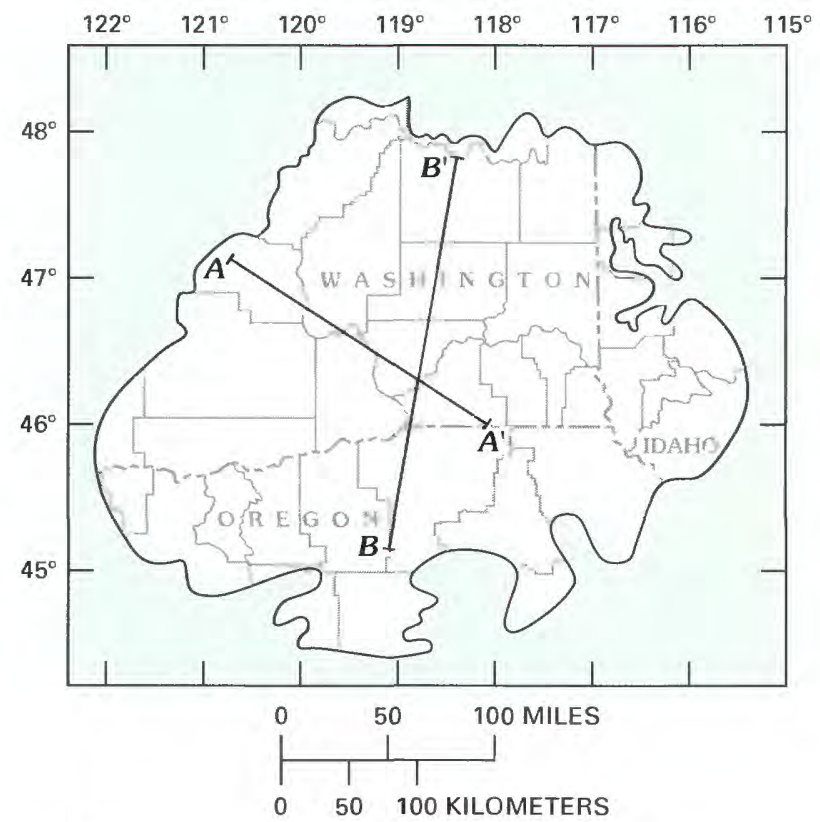

\begin{tabular}{|c|c|}
\hline & EXPLANATION \\
\hline & GEOLOGIC UNIT \\
\hline 0 & Overburden \\
\hline S & Saddle Mountains Basalt \\
\hline w & Wanapum Basalt \\
\hline G & Grande Ronde Basalt \\
\hline B & Pre-Columbia River Basalt Group \\
\hline & $\begin{array}{l}\text { GEOLOGIC CONTACT-Queried } \\
\text { where inferred }\end{array}$ \\
\hline
\end{tabular}

A

$A^{\prime}$

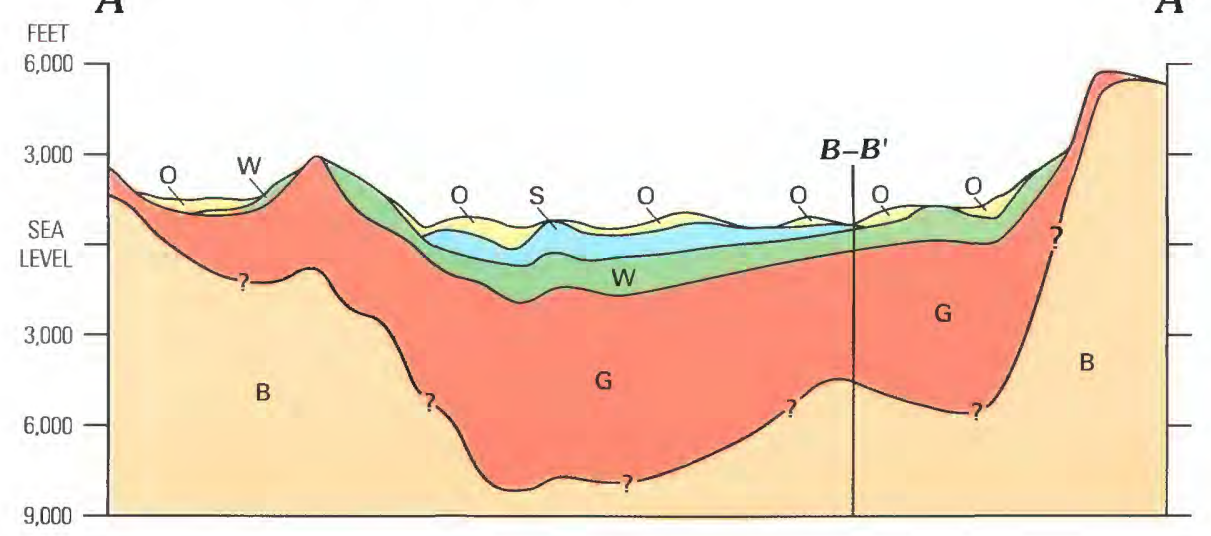

$B$

$B^{\prime}$

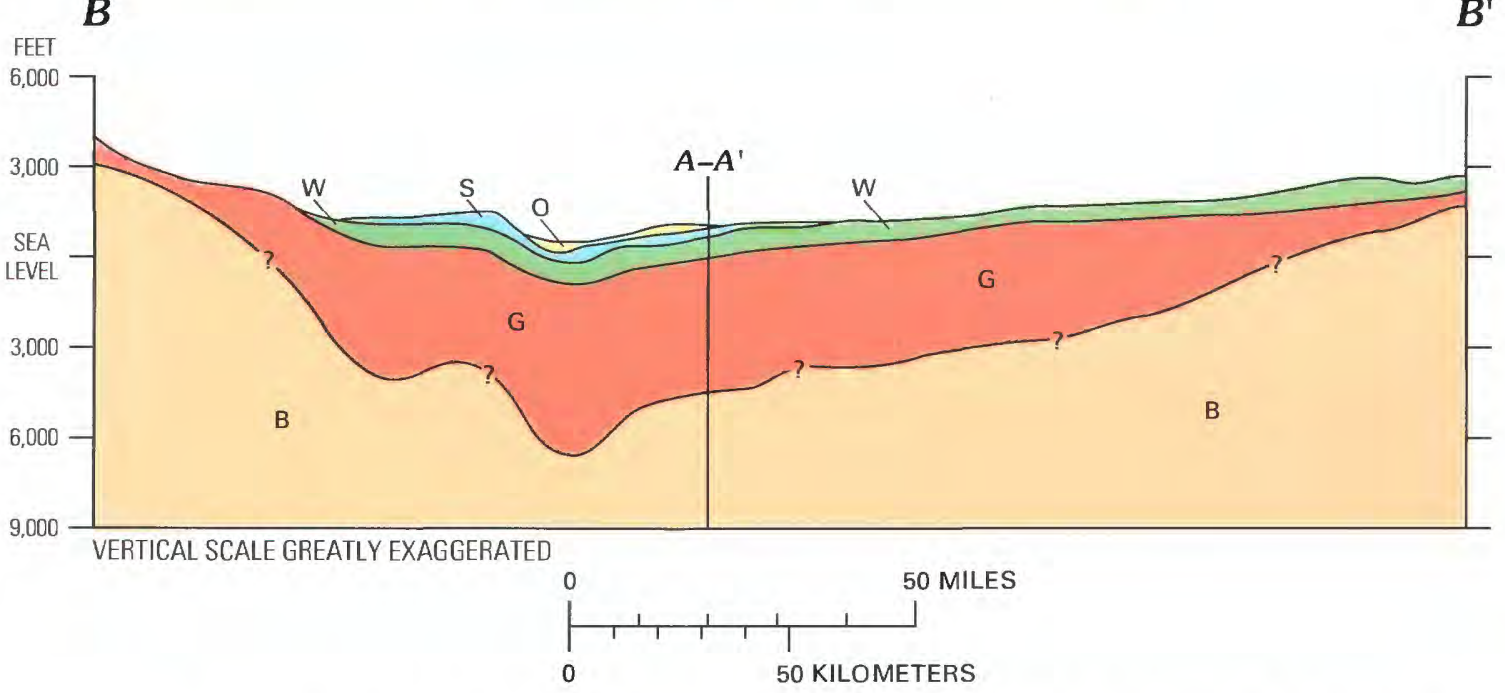

Figure 9.-Generalized geologic sections through the Columbia Plateau (from Drost and others, 1990). 


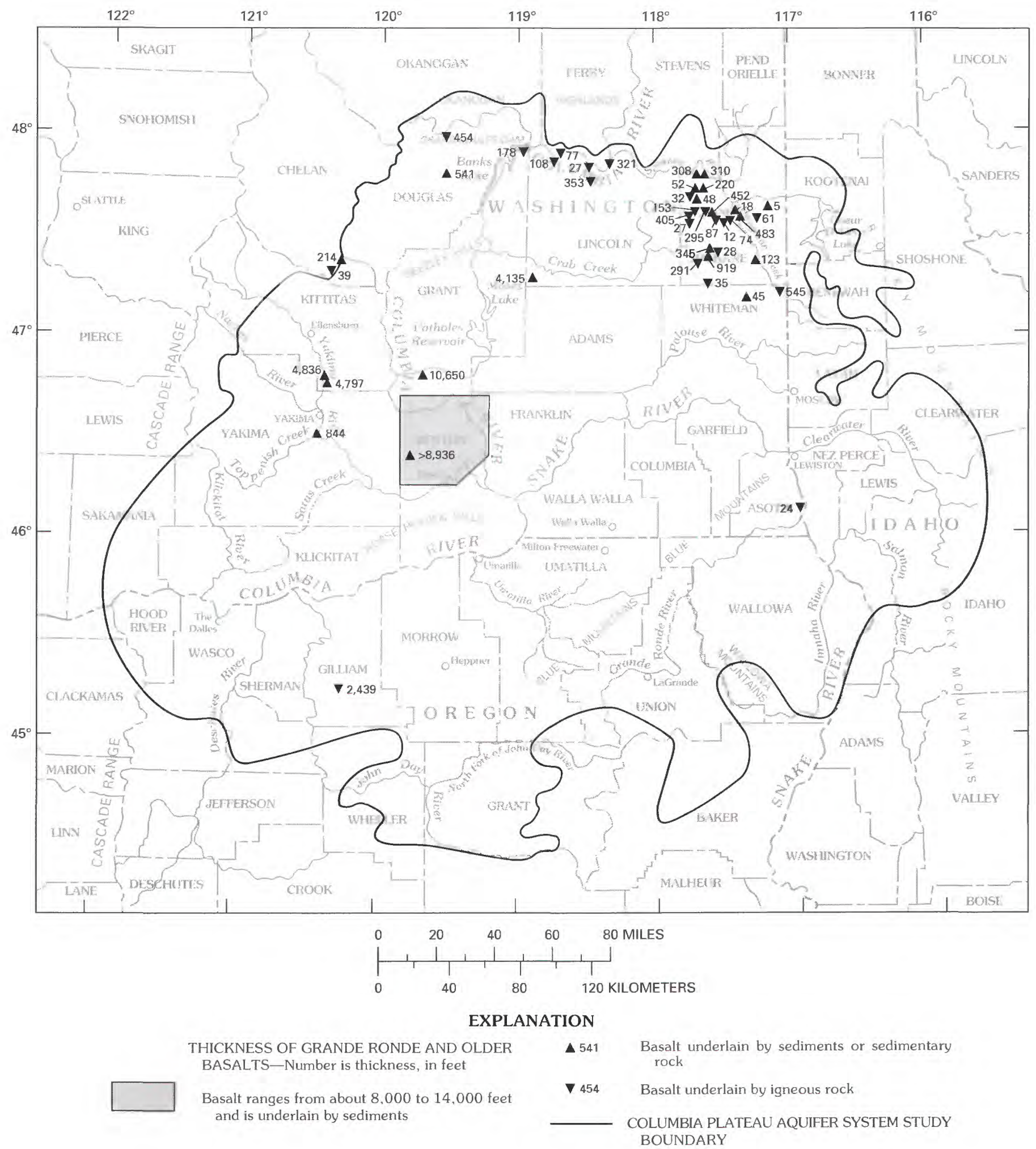

FIGURE 10 - Thickness of the Grande Ronde Basalt and older basalts. (Modified from Drost and Whiteman, 1986.) 


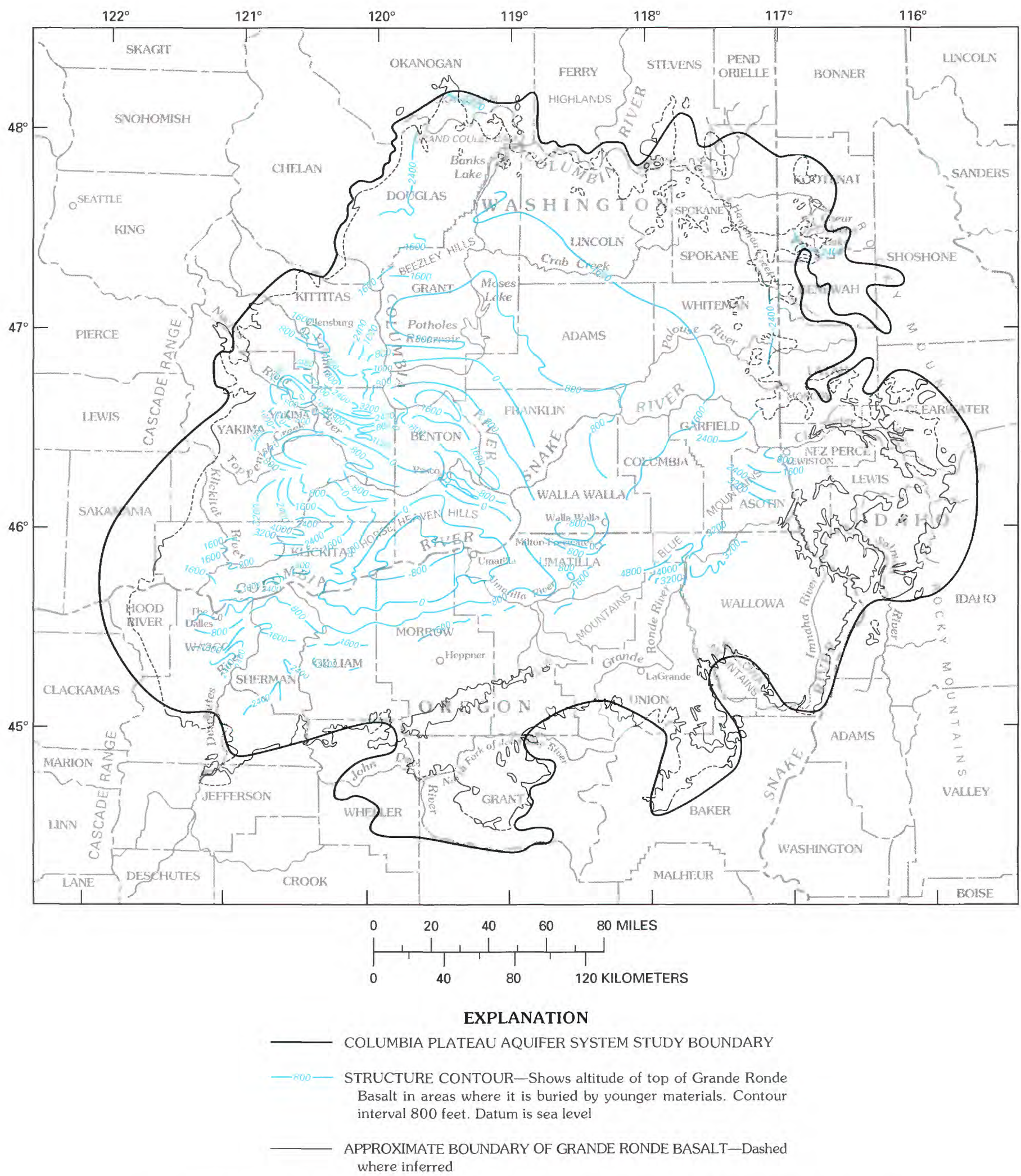

Figure 11.-Altitude of the top of the Grande Ronde Basalt. (Modified from Drost and others, 1990.) 
into four members on the basis of petrography and magnetic polarity. They are, from oldest to youngest, the Eckler Mountain, Frenchman Springs, Roza, and Priest Rapids Members. The Eckler

Mountain Member is found in southeastern Washington and northeastern Oregon, and is of limited areal extent. The three younger members are widespread on the plateau in Washington, but only the

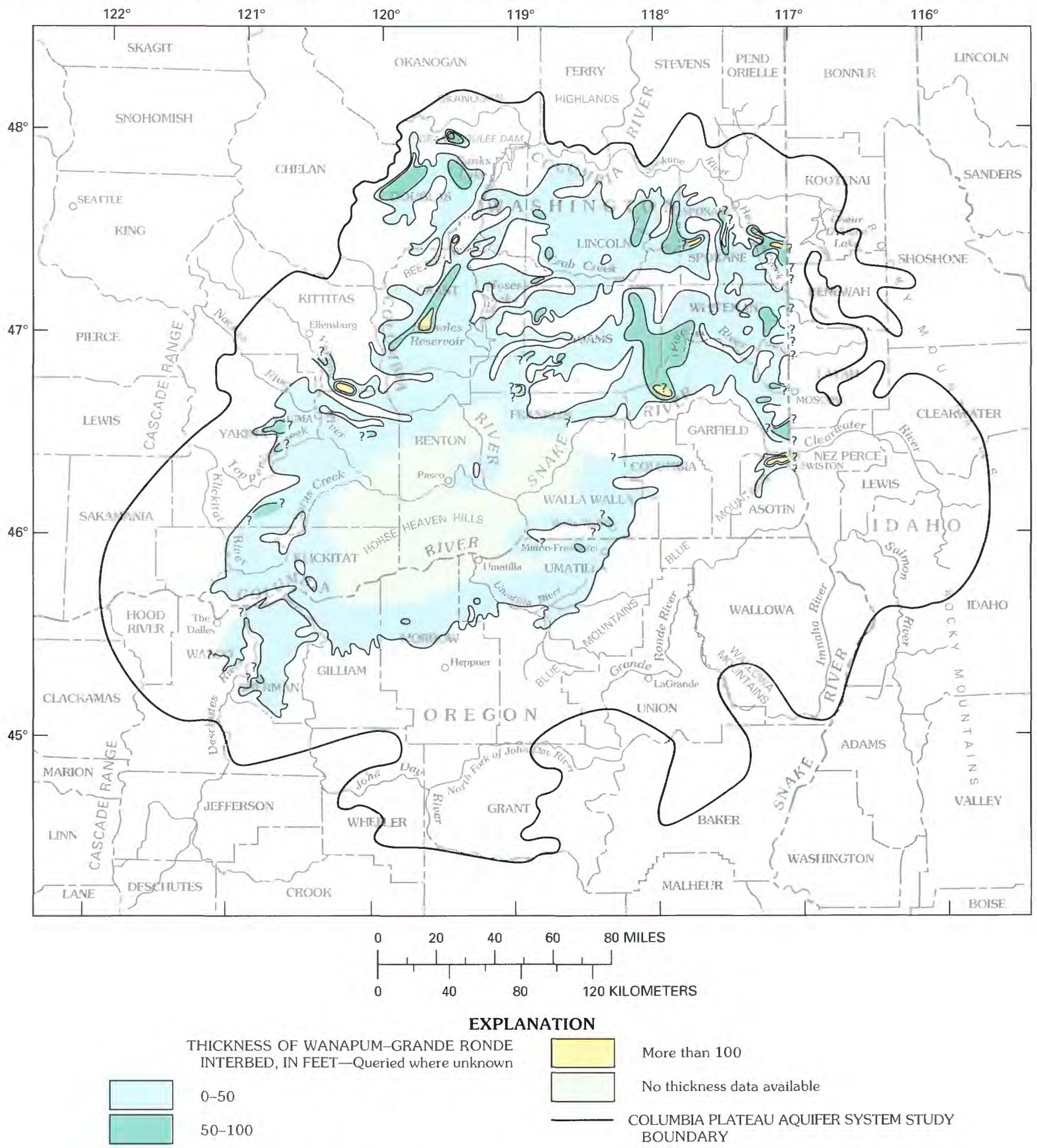

Figure 12.-Thickness of the Wanapum-Grande Ronde interbed. (Modified from Drost and others, 1990.) 
Frenchman Springs Member is widespread in Oregon. The Roza Member contains evenly distributed plagioclase phenocrysts, averaging more than 5 millimeters $(\mathrm{mm})$ in size, that make it an easily recognized and important marker bed on the plateau. Sedimentary interbeds are more abundant in the Wanapum Basalt than in the Grande Ronde Basalt but generally are thin and localized.

The combined thickness of the Wanapum Basalt flows and interbedded sediments is shown in figure 13. Thickness ranges between 0 and $1,300 \mathrm{ft}$, with the greatest thickness in the Yakima Fold Belt subprovince (fig. 1). The Wanapum Basalt is exposed extensively or is covered by a veneer of sedimentary deposits in the northeastern and southern parts of the plateau. In the central and western parts, it is overlain by younger geologic units. The altitude of the top of the Wanapum Basalt where it is buried under younger geologic units is shown in figure 14.

A sedimentary interbed is commonly present between the Wanapum Basalt and the overlying Saddle Mountains Basalt. This interbed, the Saddle Mountains-Wanapum interbed, is equivalent to the Beverly Member of the Ellensburg Formation. The Saddle Mountains-Wanapum interbed consists chiefly of clay, silt, claystone, or siltstone. Lesser amounts of sand, sand and gravel, and sandstone are reported; available data do not indicate any pattern to the distribution of these coarsegrained materials. The thickness of the Saddle Mountains-Wanapum interbed is shown in figure 15 (Drost and others, 1990); it averages about $50 \mathrm{ft}$ but generally ranges between 0 and $200 \mathrm{ft}$. The thickest section, about $250 \mathrm{ft}$, is found north of Yakima, Wash.

The Saddle Mountains Basalt, the youngest basalt formation in the Columbia River Basalt Group, consists of 10 members (Swanson and others, 1979d) and about 19 flows (Tolan and others, 1987). Of these members, only three are regional in extent, and therefore they are important components of the regional aquifer system. They are, in ascending order, the Umatilla, Pomona, and Elephant Mountain Members. Other members of the Saddle Mountains Basalt represent volumes of basalt that are either small in extent or are found as remnants of intracanyon flows in the Snake River canyon or as fillings in ancestral canyons (Swanson and others, 1979a). The Saddle Mountains Basalt constitutes less than 2 percent of the total volume of the Columbia River Basalt Group. The Saddle Mountains Basalt was extruded during a period of accelerated tectonic activity, canyon cutting, waning volcanism, and deposition of sedimentary interbeds between eruption periods of the major members. Each of the major basalt members generally consists of only one or two basalt flows. Depending on geographic location, the Saddle Mountains Basalt overlies either the Saddle Mountains-Wanapum interbed, the Wanapum Basalt, or the Grande Ronde Basalt.

Chemically, the Saddle Mountains Basalt is the most diverse of the basalt formations. The Umatilla Member is chemically distinct and is consistently finer grained than all other flows of the Columbia River Basalt Group. The Pomona Member is sparsely phyric, and the Elephant Mountain Member is fine grained and aphyric. In the area around the Grande Ronde valley, units mapped by Swanson and others $(1979 b, 1981)$ as andesite have been included in the Saddle Mountains Basalt.

The thickness of the Saddle Mountains Basalt flows and any interbedded sediments ranges from 0 to more than $800 \mathrm{ft}$ (fig. 16). Maximum thickness occurs in the Yakima River valley and the area south of Hanford, Wash. In one area in Oregon, it was estimated that the interbeds make up about 50 percent of the total thickness; however, this is not the case in most of the area. The altitude of the top of the Saddle Mountains Basalt where it is buried under younger rocks is shown in figure 17.

\section{GEOLOGIC STRUCTURES}

Geologic structures within the plateau are diverse and range from simple homoclines to sharp folds with structural relief of as much as several thousand feet. Major faults generally are associated with anticlinal folds and range from steep normal faults to low-angle reverse faults. Major geologic structures within the plateau, simplified from the work of Drost and others (1990), Drost and Whiteman (1986), and Gonthier (1990), are shown in figure 18. The discussion of structures that follows is by geographic regions or subprovinces wherein the types of structural deformation appear to be grossly similar.

The Palouse subprovince is structurally simple and is underlain by basalt flows that dip less than $5^{\circ}$ toward the southwest. Superimposed on the southwesterly dipping basalt are a few broad, open, northwest-trending folds with amplitudes of only a few tens of feet. Northwest-trending topographic lineaments are present in the Palouse that may represent fracture zones along which the rock is more readily eroded. No offset or displacement along them has been identified. 

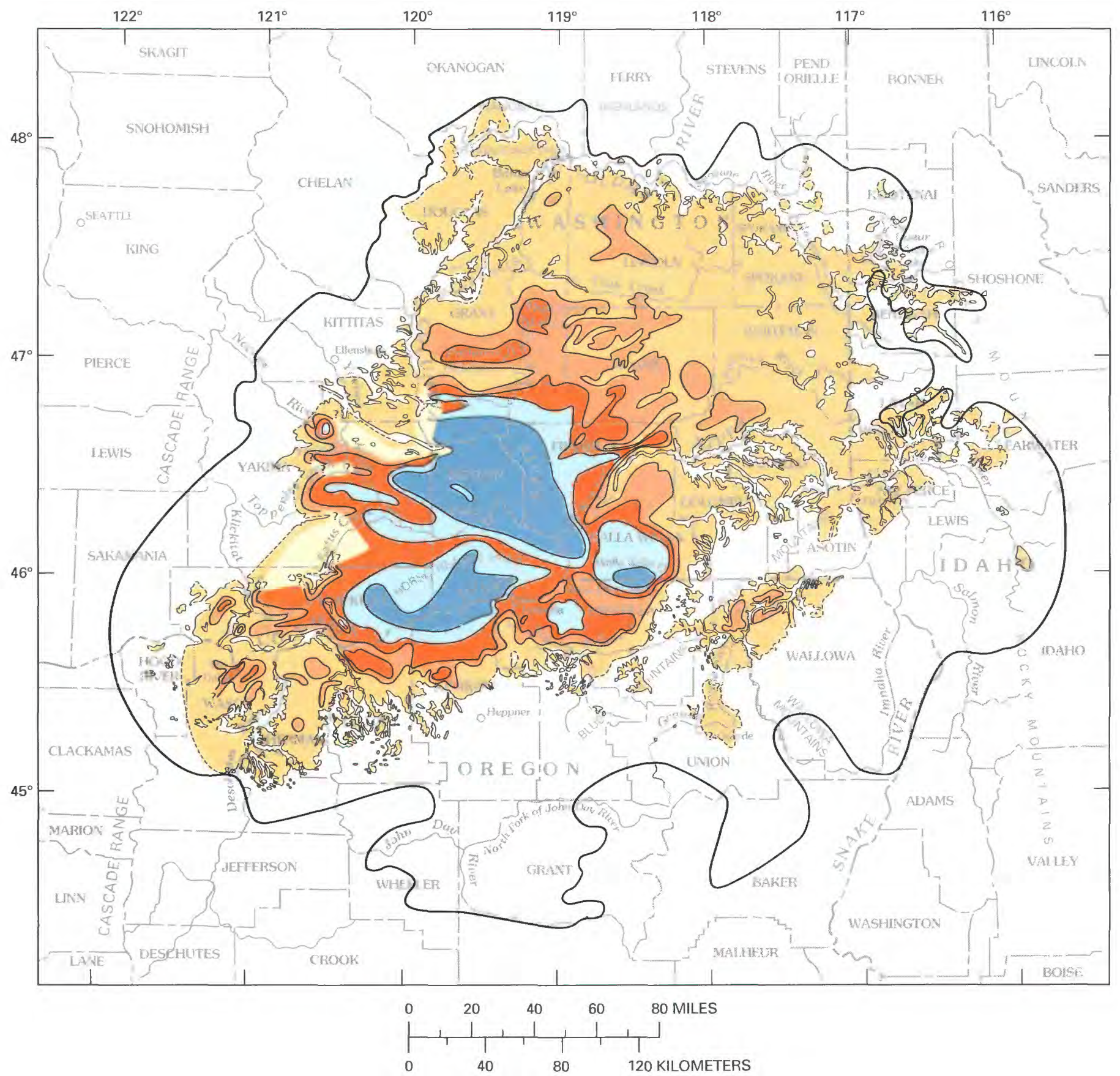

\section{EXPLANATION}

THICKNESS OF WANAPUM BASALT AND INTERBEDDED SEDIMENTS, IN FEET-Queried where unknown

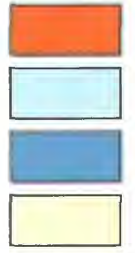

$400-600$
$600-800$

$800-1,000$

More than 1,000

No thickness data available
COLUMBIA PLATEAU AQUIFER SYSTEM STUDY BOUNDARY

APPROXIMATE BOUNDARY OF WANAPUM BASALT-Dashed where inferred

Figure 13.- Thickness of the Wanapum Basalt and interbedded sediments. (Modified from Drost and others, 1990.) 


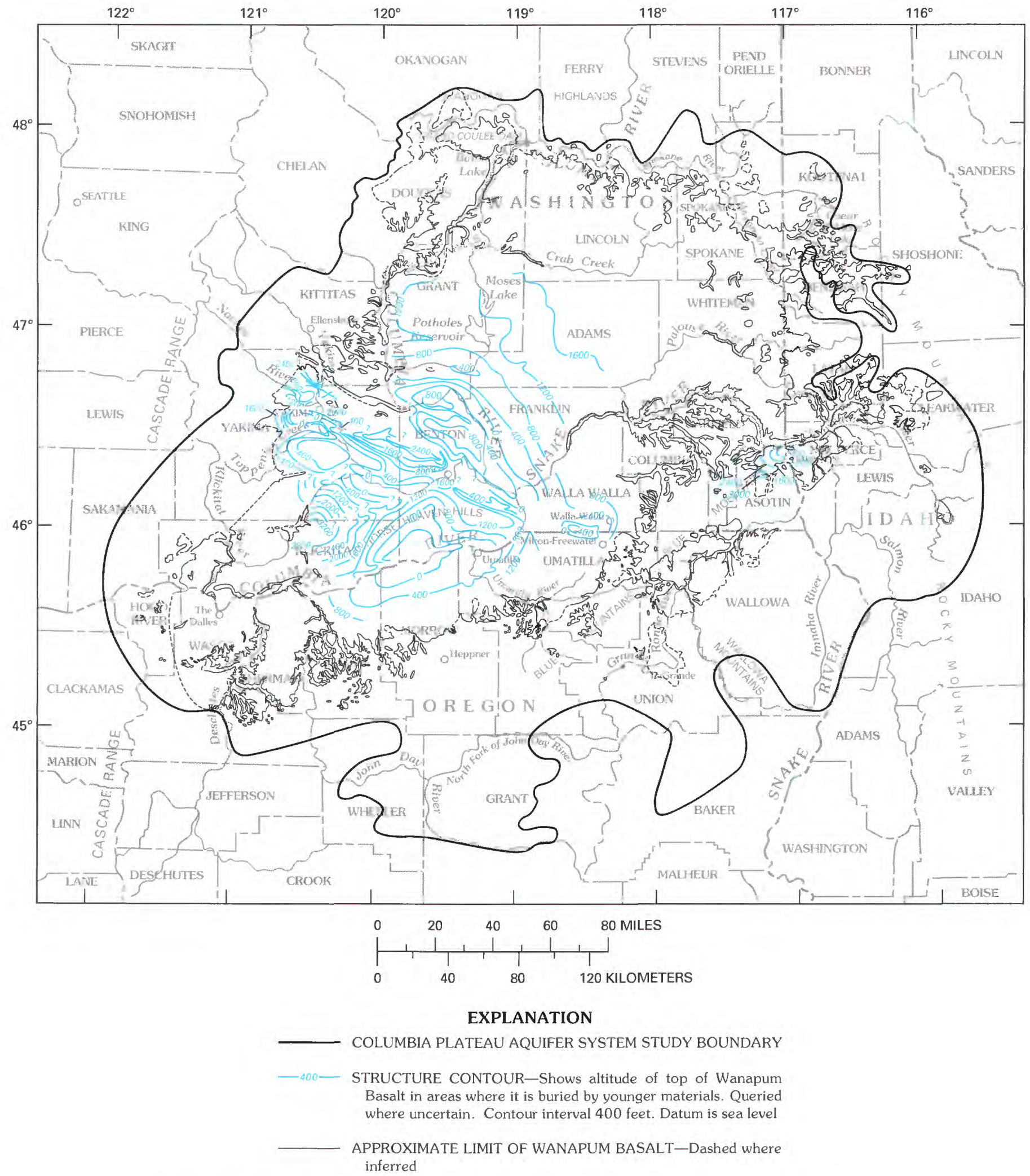

FIgure 14.-Altitude of the top of the Wanapum Basalt. (Modified from Drost and others, 1990.) 


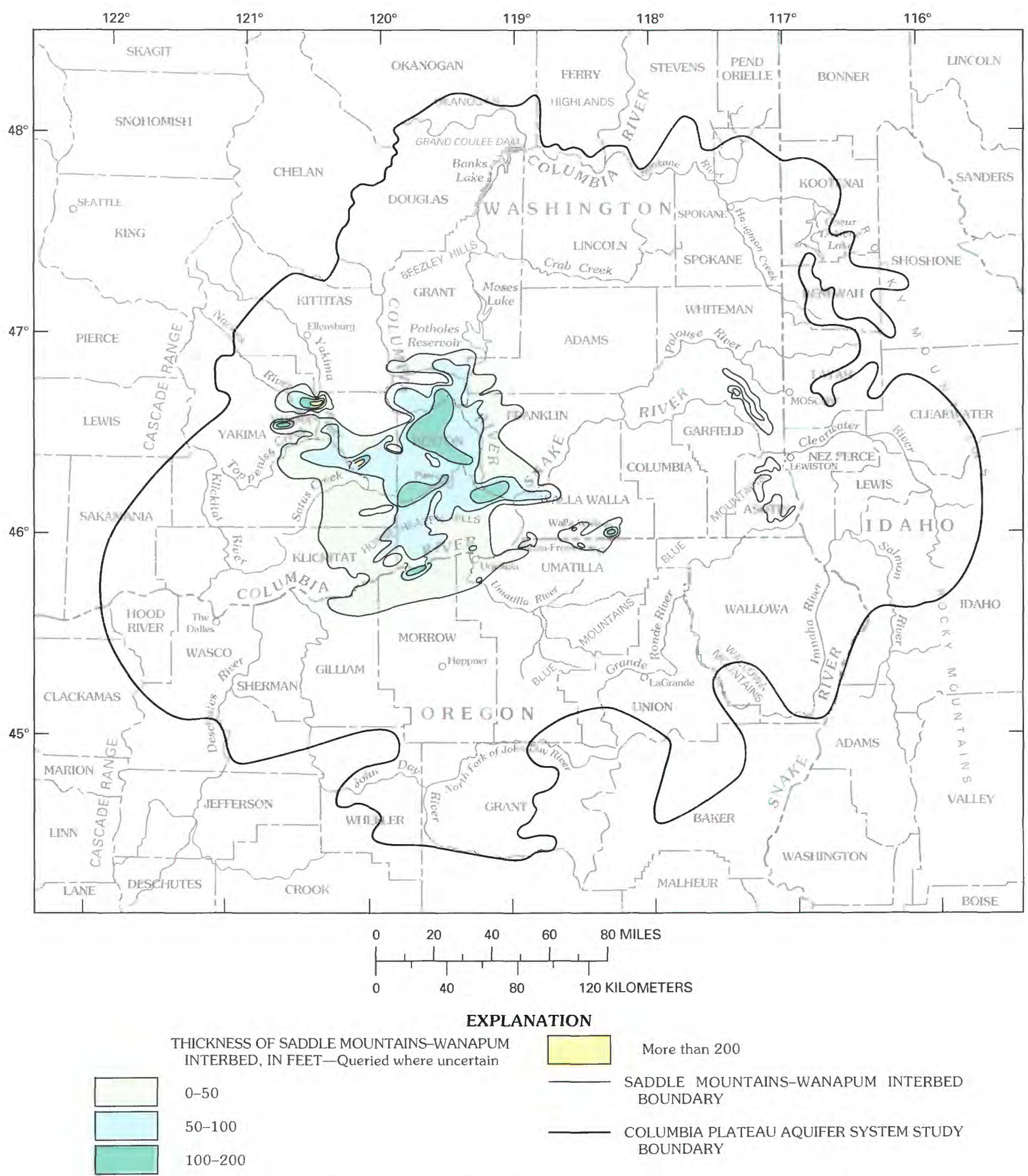

Figure 15.-Thickness of the Saddle Mountains-Wanapum interbed. (Modified from Drost and others, 1990.) 


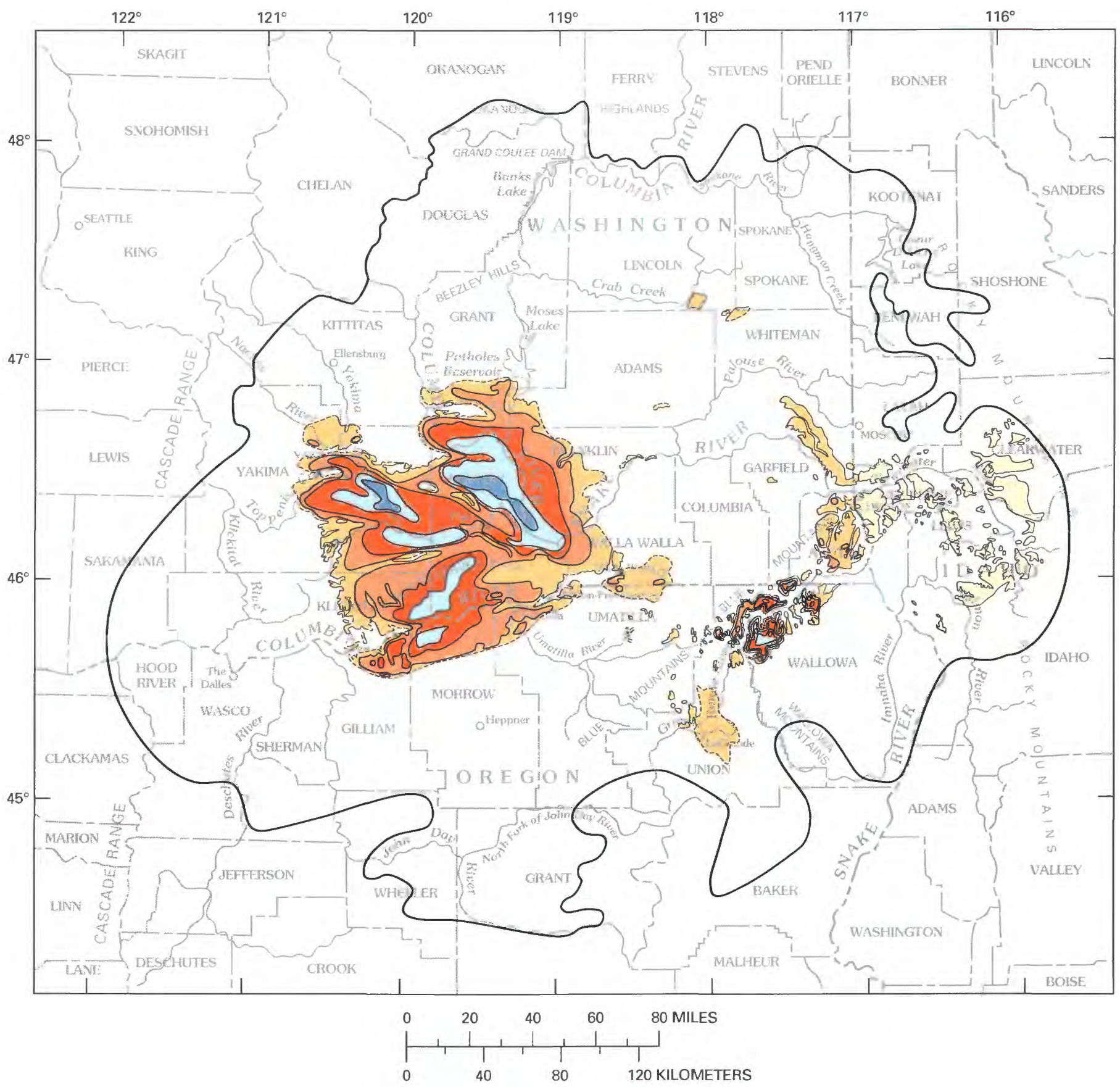

EXPLANATION

THICKNESS OF SADDLE

MOUNTAINS BASALT

AND INTERBEDDED

SEDIMENTS, IN FEET

$0-200$

200-400

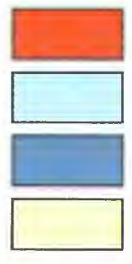

400-600

$600-800$

More than 800

Insufficient data for contouring;

however, thicknesses are

generally under 200 feet
COLUMBIA PLATEAU AQUIFER SYSTEM STUDY BOUNDARY

APPROXIMATE LIMIT OF SADDLE MOUNTAINS BASALT-Dashed where inferred

Figure 16-Thickness of the Saddle Mountains Basalt and interbedded sediments. (Modified from Drost and others, 1990.) 


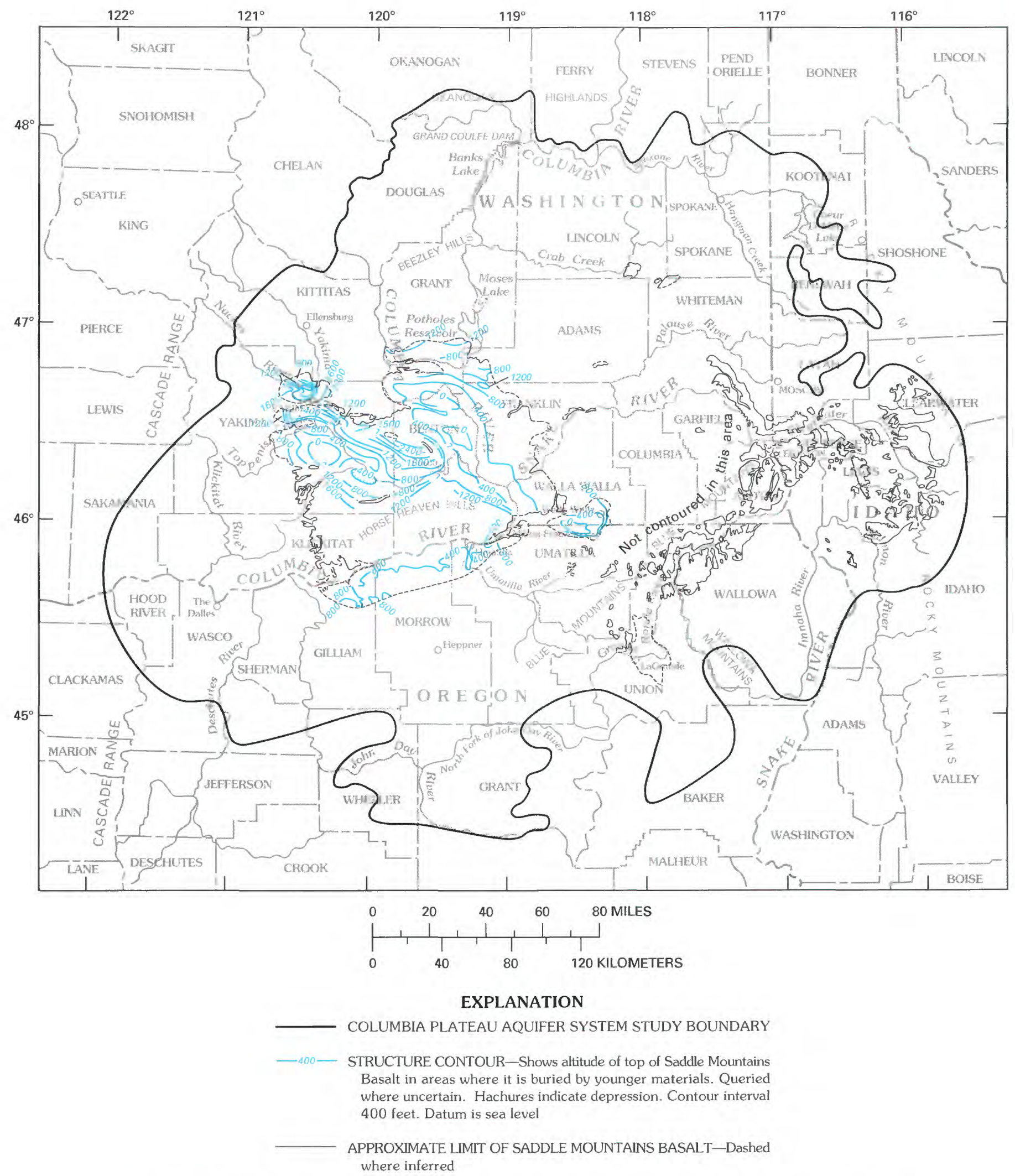

FIGURE 17.-Altitude of the top of the Saddle Mountains Basalt. (Modified from Drost and others, 1990.) 

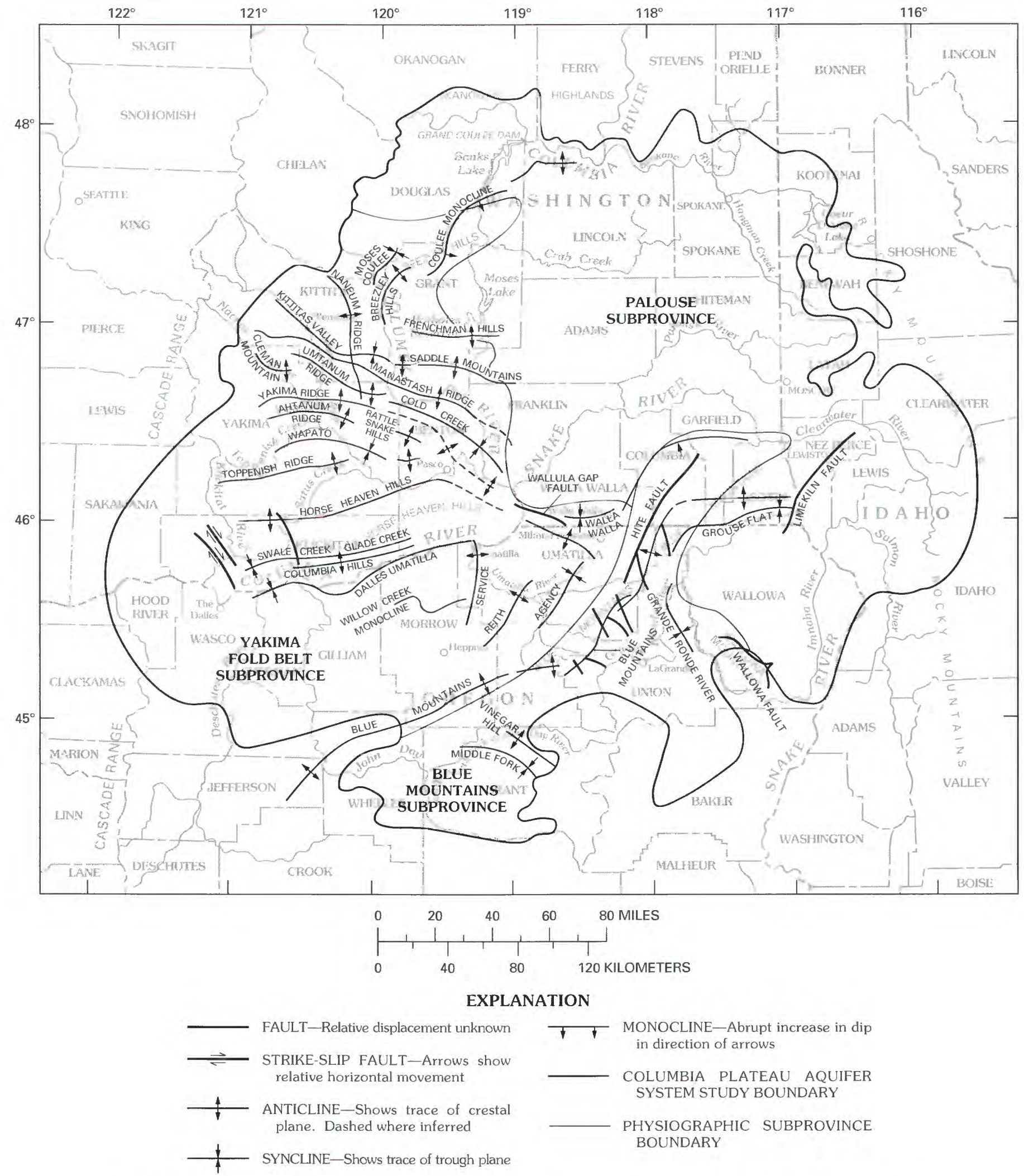

Figure 18--Major geologic structures within the Columbia Plateau. (Modified from Drost and others, 1990.) 
The dominant feature of the Yakima Fold Belt subprovince is a series of narrow, asymmetrical anticlinal ridges, trending east-west to northwest and plunging east and southeast, that are generally separated by broad, flat-floored synclinal valleys. From south to north, the most prominent anticlinal ridges are the Columbia Hills, Horse Heaven Hills, Toppenish Ridge, Ahtanum Ridge, Rattlesnake Hills, Yakima Ridge, Umtanum Ridge, and Manastash Ridge. At the eastern ends of those ridges, each ridge intersects or is sharply deflected in a southeasterly direction along a 125 -mi-long zone that extends between Cle Elum and Wallula, Wash. This zone is a segment of a larger lineament known as the Olympic-Wallowa lineament that extends northwest-southeasterly between the Olympic Mountains in northwestern Washington (more than $100 \mathrm{mi}$ from the study area) and the Wallowa Mountains in northeastern Oregon.

Principal anticlinal ridges in the Yakima Fold Belt subprovince range in length from 35 to 150 $\mathrm{mi}$. In general, folds in this subprovince are asymmetrical, with amplitudes ranging from nearly flat to overturned. Large segments of some folds are cut by low-angle reverse faults that parallel the ridges. Reverse faults cut both limbs of some anticlines and form box folds. This style of folding persists north of the $125-\mathrm{mi}$ zone between Cle Elum and Wallula, but the folds diminish in amplitude. The east-west and northwest-southeast fold trend is crossed at right angles by sinuous folds trending northeast, one of which is the Beezley Hills anticline.

In Oregon, south of the Columbia Hills, the basalt dips toward the axis of The Dalles-Umatilla syncline; this syncline roughly follows the south shore of the Columbia River and forms a broad, asymmetrical synclinal basin. The south limb of the syncline is formed by gently north-dipping basalt that forms the north flank of the Blue Mountains anticline. Pre-Columbia River Basalt Group rocks that form the core of the Blue Mountains are exposed in a few places. The dip slope is crossed by gentle monoclinal flexures; by broad, open, small-amplitude folds; and by one or two narrow bands of tight asymmetrical folds. These fold types trend east-west to northeasterly, roughly parallel to the axis of the nearby major structure, the Blue Mountains anticline. A series of lineaments trending northwest, narrow fold belts, and faults with minor strike-slip displacements crosses the southwest part of the fold belt and adds a prominent structural grain to the region. Collectively, the geologic structures in the Yakima Fold Belt subprovince suggest that the folds were formed in a stress field in which the maximum stress was oriented in the north-south direction (Reidel, 1984).

The eastern part of the Blue Mountains subprovince was the vent area for much of the Columbia River Basalt Group flows. It is a rugged, uplifted area consisting of remnants of a plateau surface and deeply dissected canyons with up to a few thousand feet of local relief. The most prominent structural feature is the broad-crested Blue Mountains anticline and a belt of asymmetrical folds that diverge easterly from its northeastern end. The crestal area of the anticline is crossed by numerous northwest-trending high-angle normal faults, as well as by lineaments with no apparent displacement. Southeast of this crestal area, centered near La Grande, Oreg., is a major graben bounded by normal faults with a similar northwestern trend. The area south of the Blue Mountains anticline and west of the graben is marked by northwest- to west-trending, broad, open, lowamplitude folds and, in places, by somewhat similarly trending normal faults. East of the graben, the principal structures are widely spaced normal faults.

Numerous linear, northwest/southeast-trending, en echelon basalt feeder-dike complexes have been identified in the southeastern part of the plateau in both Washington and Oregon. Similar dike complexes are believed to be covered by younger basalt in these areas and possibly elsewhere. Although they are not strictly a geologic structure, their effects on the movement of ground water are similar to those of geologic structures. The feeder dikes are commonly a few to several feet wide and many miles long, and generally they are vertical to steeply dipping. They tend to crosscut older basalt flows and generally consist of dense, fine-grained basalt.

\section{INTERNAL STRUCTURE OF BASALT FLOWS}

Individual flows of the Columbia River Basalt Group range in thickness from a few inches to more than $300 \mathrm{ft}$ (Swanson and others, 1979c). The internal structure of a typical flow consists of four sections - the flow top, the entablature, the colonnade, and the flow base (fig. 19). The flow top (called the interflow zone where superimposed with the base of an overlying flow) generally is vesicular basalt with scoria and clinker. The entablature consists of small-diameter columns in fan-shaped arrangements. Hackly joints are common, and the upper part of the entablature is commonly vesicular. The colonnade is made up of nearly vertical three- to eight-sided columns bounded by cooling joints. The columns average $3 \mathrm{ft}$ in diameter and 
$25 \mathrm{ft}$ in length. Columns commonly are crosscut by systems of nearly horizontal joints, and a vesicular zone is commonly present at the base of the colonnade. The base of the flow generally has a thin zone of glassy basalt and may be marked by a zone of pillow basalt. These four sections are usually recognizable in individual basalt flows; however, the degree of development of jointing in each section varies markedly, both laterally within flows and vertically among them. Colonnades and entablatures range from poorly to well developed; typically, if one is well developed, the other is barely recognizable.

\section{BASALT ROCK MECHANICS}

For regional ground-water investigations, the most important rock properties are porosity, density, bulk and Young's modulus of elasticity, and permeability. Laboratory data are available within the study area for these five properties. Laboratory

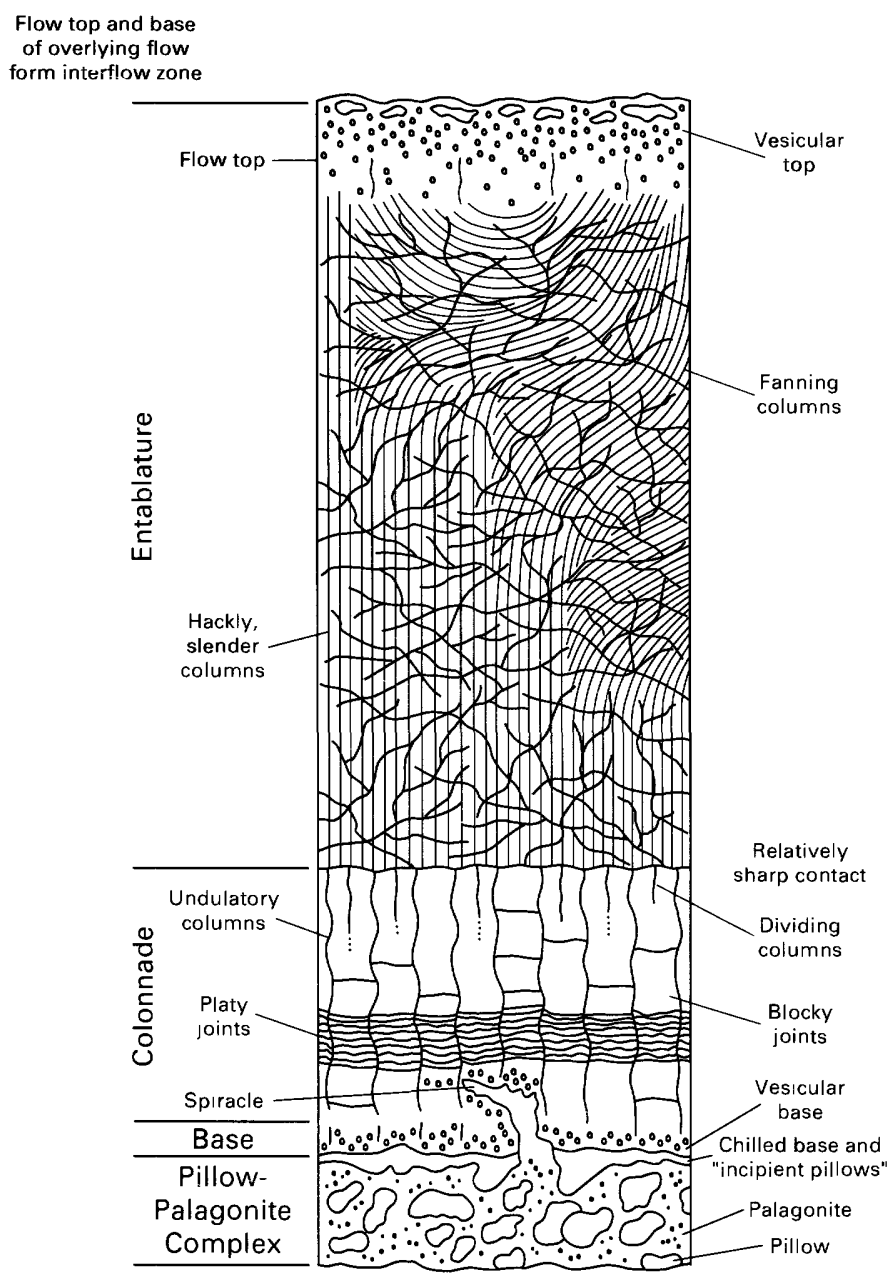

FiguRE 19.-Generalized diagram showing a typical basalt flow in the Columbia River Basalt Group. (Modified from Swanson and Wright, 1978.) values of permeability from core samples probably are not representative of the fractured basalts; however, initial estimates of hydraulic conductivity based on specific-capacity data are presented in the section "Hydraulic Characteristics." Similarly, laboratory values of bulk and Young's modulus are not presented because they were made for core samples, and may have little relation to the values of the composite skeletal structure of the basalt flows. Information on porosity and density for the Columbia River Basalt Group (Sublette, 1986) are summarized in table 4. Most of the data are from laboratory tests and investigations on the Hanford Nuclear Reservation site in central Washington.

The porosity of basalt is dependent on chemical composition of the basalt, temperature of extrusion, rate of cooling, flow thickness, and degree of diagenesis that the basalt has undergone. In discussing the hydrogeology of volcanic rocks, Wood and Fernandez (1988) reported that, on the basis of a worldwide sampling of volcanic rocks, basalts have total porosities ranging from 1 to 70 percent and that effective porosities have a much smaller range than the total porosities, averaging less than 5 percent. According to Wood and Fernandez (1988), the bulk density of vesicular basalts ranges from 0.083 to $0.090 \mathrm{lb} / \mathrm{in}^{3}$, and that of dense basalts from 0.098 to $0.105 \mathrm{lb} / \mathrm{in}^{3}$, with an average grain density of $0.105 \mathrm{lb} / \mathrm{in}^{3}$. These values are similar to those given in table 4 . An average porosity of about 4 percent is indicated by the density values; thus, the higher porosity values in table 4 indicate that fracturing has increased the porosity, as suggested by Wood and Fernandez (1988).

\section{HYDROLOGY}

The primary factors controlling the occurrence, movement, and availability of ground water in the Columbia Plateau are the hydrologic characteristics of the geologic units underlying it, the climate, and water-supply development practices. The following sections describe the hydrologic framework of the Columbia Plateau aquifer system and, where appropriate, relate the hydrology to the geologic, climatic, and cultural characteristics that affect the availability and quality of ground water.

\section{RELATION BETWEEN GEOLOGIC AND HYDROLOGIC FRAMEWORKS}

The geologic characteristics of the rock materials underlying the Columbia Plateau are varied and complex because of formational, emplacement, and 
TABLE 4.-Rock-mechanics data for the Columbia River Basalt Group (from Sublette, 1986)

[Density values given in pounds per cubic inch; porosity given in percent]

\begin{tabular}{|c|c|c|c|c|}
\hline Intraflow structure & $\begin{array}{c}\text { Grain } \\
\text { density }\end{array}$ & $\begin{array}{c}\text { Bulk } \\
\text { density }\end{array}$ & $\begin{array}{c}\text { Effective } \\
\text { porosity }\end{array}$ & $\begin{array}{c}\text { Total } \\
\text { porosity }\end{array}$ \\
\hline \multicolumn{5}{|l|}{ Flow-top and vesicular zone $e^{1}$} \\
\hline Representative value ------- & 0.104 & 0.084 & 14.45 & 20.98 \\
\hline 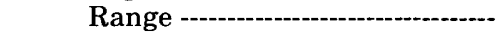 & $0.097-0.101$ & $0.065-0.10$ & $1.60-41.60$ & $7.20-35.80$ \\
\hline Number of samples ------- & 33 & 171 & 163 & 32 \\
\hline \multicolumn{5}{|l|}{ Entablature and colonnade ${ }^{1}$} \\
\hline Representative value & 0.104 & 0.102 & 1.85 & 2.85 \\
\hline 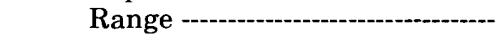 & $0.102-0.101$ & $0.092-0.104$ & $0.20-12.40$ & $0.00-13.00$ \\
\hline Number of samples --_- & 113 & 360 & 356 & 106 \\
\hline \multicolumn{5}{|l|}{ Entablature $^{2}$} \\
\hline Representative value & 0.107 & 0.101 & 1.73 & 6.23 \\
\hline 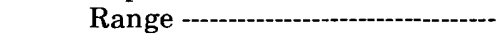 & $0.100-0.115$ & $0.087-0.109$ & $0.10-5.30$ & $0.40-13.70$ \\
\hline
\end{tabular}

${ }^{1}$ Based on samples from wells located within a small area of the Hanford Nuclear Reservation.

${ }^{2}$ Based on samples from wells scattered throughout the Hanford Nuclear Reservation and on reports from various investigations.

diagenetic processes. In order to define the occurrence, movement, and quality of ground water within such a complex geologic system, it is necessary to conceptualize and relate the geological and hydrological frameworks into a simpler system, or a conceptual model, that provides a basis for evaluating the hydraulic characteristics, the groundwater recharge and discharge, and the movement of ground water in the Columbia Plateau aquifer system. In order to accomplish this task, the following aspects need to be considered: the relation of the overburden in the hydrologic framework, the flow of ground water through the basalt, the relation of the sedimentary interbeds, and the effect of geologic structures on the movement of ground water.

Most of the lowlands of the plateau are basins in which the Columbia River Basalt Group is overlain by sediments and sedimentary rocks. These rocks range from shales and clays to conglomerate and gravel, but they are generally coarse grained and permeable in their upper sections and finer grained and less permeable at depth. They transmit water readily and constitute a water-table aquifer where they are saturated. The average hydraulic conductivity can be several orders of magnitude larger than that of the basalt.

The movement of water through basalts is governed by numerous factors that affect the nature of individual flows. These factors include the topographic surfaces over which the basalts flowed; the erosional processes that occurred before, during, and after extrusion; the deposition of interbeds; tectonic activity; and diagenetic processes. For example, lava flows that fill valleys and canyons could leave a smooth surface for extrusion of later flows. These later flows might have extensive lat- eral continuity, but the earliest flows would be localized. Tectonic activity, basin subsidence, and formation of folds can distort emplaced lava flows and affect the distribution of subsequent flows. Moving water can erode flows, ponding water can quench solidifying flows, and lava flowing into standing water can form porous pillow-palagonite complexes. Thus, the lateral continuity, thickness, and composition of individual flows (particularly interflow zones) are highly varied. The degree of variation in the entablature and colonnade of a flow further complicates the understanding of water movement in the basalts.

The basalt is an extremely heterogeneous aquifer unit that transmits water most readily through the broken vesicular and scoriaceous interflow zones that commonly constitute 5 to 10 percent of the thickness of an individual basalt flow (fig. 19). The interflow zones are separated by the less transmissive and more massive entablature and colonnade (fig. 19), in which the fractures are more or less vertical. Lateral ground-water movement in the entablature and colonnade is probably negligible when compared with the volume of water that moves laterally through the interflow zones. This is because movement of water in the entablature and colonnade is controlled by fractures and joint systems, whereas movement of water in the interflow zones is controlled by primary features such as flow breccia, clinkers, and vesicles. Vertical movement of ground water between interflow zones is much less per unit area than lateral movement but is large over the entire aquifer area. Vertical movement of ground water varies because of the structure of individual flows and the hydraulic characteristics of the interbeds. 
The lithology of sedimentary interbeds between basalt flows within a formation varies from shales to sands and gravels. Except in the Saddle Mountains Basalt, most interbeds within the basalt formation are of a very limited extent. The interbeds between the basalt formations are fairly extensive laterally but are thin when compared with basalt formations. These interbeds may be locally transmissive and function as aquifers, but in general they probably impede the vertical movement of water. Water levels and well-log data suggest that the interbeds generally act as semiconfining to locally confining layers that transmit small amounts of water laterally. This conclusion is further supported by the fact that, locally, lateral hydraulic conductivities of the interbeds are much smaller than those of the interflow zones.

Newcomb (1961, 1969) discussed the effect of tectonic structures on ground-water flow in the basalt. In an analysis of the flow system in an area near The Dalles, Oreg., he postulated that tight anticlinal folding of basalt formed breccia and fault gouge between individual lava flows in the axial region of the fold that decreased the permeability of the basalt in the axial region, thus impeding ground-water flow across the axis. It is also possible that feeder dikes, individually or in series, could impede ground-water movement, especially if oriented transversely to the hydraulic gradient. Lack of observation wells and pumping centers near the axis of folds or feeder dikes makes it difficult to assess their control on the movement of ground water.

The relation between the geologic framework and the hydrologic framework that provides a basis for the study of a regional flow system is shown in figure 20. This relation provides a simpler system for study and is the foundation for the conceptual model for describing ground-water flow in the Columbia Plateau aquifer system. Thus, for study purposes, the aquifer system was divided into seven units-the overburden aquifer, three basalt units, and three confining units (fig. 20).

The sediments and sedimentary rocks forming the overburden are considered a single unit. Because of the large difference in hydraulic conductivity between the overburden and the basalt, the unit is considered a separate aquifer, herein referred to as the overburden aquifer.

The basalt aquifers can be described only generally because of the number and complexity of individual basalt flows and the lack of data to define them in detail. The combining of 100 or more individual basalt flows into study units has been done by following a division similar to that of the Yakima Basalt Subgroup. This subgroup and its intercalated sediments were divided into three basalt study units: the Saddle Mountains unit, the Wanapum unit, and the Grande Ronde unit (fig. 20). Each unit includes the intercalated sediments within the basalt formation. Additionally, in the southeastern part of the study area, the Imnaha Basalt is included in the Grande Ronde unit. The term "unit" or "units" is used to distinguish them from the basalt formations, which formally do not include the intercalated sediments.

The Saddle Mountains-Wanapum and Wanapum-Grande Ronde interbeds are two of the confining units. Because these units are thin, locally missing, of a smaller lateral extent than the basalt units they overlie, and at some locations consist of rock materials that are at least as permeable as the basalts, they are not formally named. They simply have been called confining units for the division of the aquifer system that relates the geologic and hydrologic frameworks in this study. The prebasalt basement rocks generally have much lower permeabilities than the basalts and are considered to be the base of the regional aquifer system. These basement rocks are called the basement confining unit.

The conceptual model of the ground-water flow in the Columbia Plateau aquifer system, based on the relation between the geologic and hydrologic frameworks, is shown in figure 21. The area for which the hydrologic framework information in the following sections is presented is limited to about $32,800 \mathrm{mi}^{2}$ of the study area. This hydrologic study area also represents the boundaries of the numerical ground-water-flow model constructed during this study. The relation between the hydrologic study area, the areal extent of the Columbia River Basalt Group (which extends beyond the boundary of the described aquifer system), and the Columbia Plateau RASA study area is shown in figure 22.

\section{HYDRAULIC CHARACTERISTICS}

Most of the lateral hydraulic conductivity values discussed in this report are depth-integrated average values that represent the general hydraulic characteristics of the entire study-unit thickness. Vertical hydraulic conductivities are largely unknown. Application of aquifer testing methods for estimating vertical hydraulic conductivity of the basalts is difficult and prone to error. However, where fine-grained interbeds are present, the interbeds control vertical ground-water movement, 
and vertical hydraulic conductivity then can be estimated on the basis of the hydraulic characteristics of the interbed lithology. Otherwise, vertical hydraulic conductivities may only be estimated by numerical ground-water-flow model simulation. Such estimates represent the integrated effects of the basalt flows and the confining unit, if present, between two units.

The initial values of lateral hydraulic conductivities for each basalt unit were estimated from drillers' specific-capacity data using the combined method of Theis (1963) and of Ferris and others (1962). In this method, the Theis equation is used to calculate transmissivity, which is the product of the hydraulic conductivity and the saturated thickness and is "equal to an integration of the hydraulicconductivity values across the saturated part of the aquifer perpendicular to the flow paths" (Lohman and others, 1972). However, the transmissivity calculated from specific-capacity data was assumed to be the product of the hydraulic conductivity and the thickness of the aquifer open to the wells. This transmissivity was then divided by the length of the open section or screened interval in a well to obtain a vertically averaged lateral hydraulic conductivity at that interval. The lateral hydraulic conductivity value estimated on the basis of specific-capacity data is probably high because of the effects of the vertical flow of water within the interval.

The vertically averaged lateral hydraulic conductivity of the overburden aquifer at any given location is dependent on the distribution of the materials that compose the aquifer. The types of sediment present in the overburden (discussed previously in the "Overburden" subsection) range from

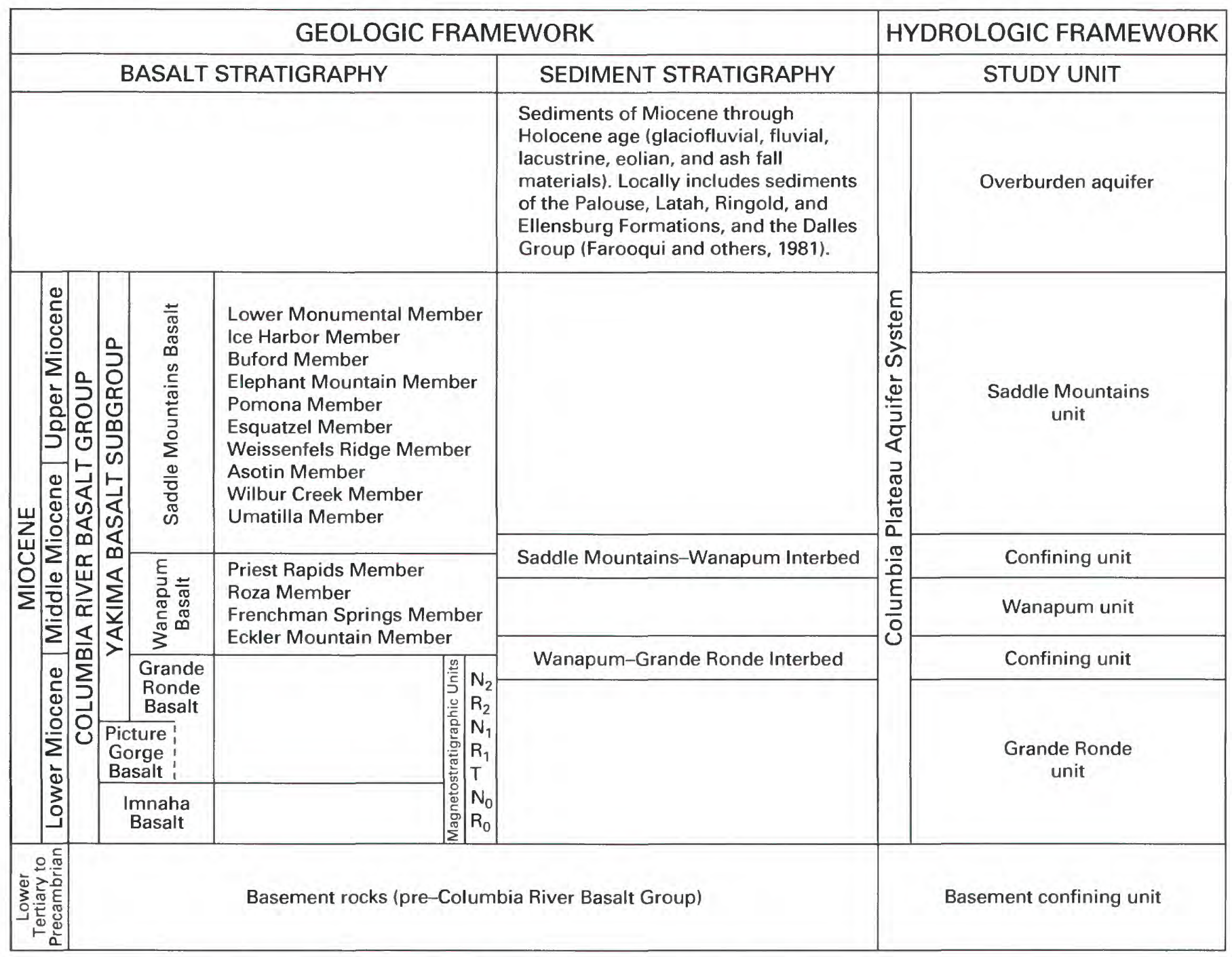

Figure 20.-Correlation of geologic framework with hydrologic framework. See figure 7 for explanation of magnetostratigraphic units. 
fine to coarse materials. Estimates of lateral hydraulic conductivity made from specific-capacity data were supplemented with data from previous studies by Tanaka and others (1974), MacNish and Barker (1976), Bolke and Skrivan (1981), Prych (1983), H.H. Bauer (U.S. Geological Survey, written commun., 1984), and B.W. Drost (U.S. Geological Survey, written commun., 1988). Estimates from previous studies were based on specific-capacity data, aquifer tests, and numerical ground-water-flow modeling. The frequency distribution of the lateralhydraulic-conductivity data for the overburden aquifer is shown in figure 23 . The values range from about 0.02 to $150,000 \mathrm{ft} / \mathrm{d}$, with a median lateral hydraulic conductivity of about $240 \mathrm{ft} / \mathrm{d}$. Fifty percent of the values about the median lie in the range 45 to $1,000 \mathrm{ft} / \mathrm{d}$. The areal distribution of hydraulic conductivity for the overburden aquifer is presented in figure 24. This distribution is based on specific-capacity data, and thus values might be high; in areas with no data, lower values ( 1 to $5 \mathrm{ft} / \mathrm{d}$ ), representative of loess, were assumed to be the best estimate.

Ideally, estimates of aquifer conductivities are made by conducting tests on wells that fully penetrate the aquifer of interest and that are cased off above and below that aquifer zone. Because of the variability in hydraulic conductivities caused by folds, faults, basalt-flow thickness, and intercalated sedimentary material, many hundreds of such aquifer tests would be necessary to delineate properly the hydraulic-conductivity distribution throughout the basalt part of the aquifer system. Relatively few such aquifer tests have been made. Indeed, cased wells completed in basalt on the plateau are rare. However, a large number of specific-capacity values for domestic, irrigated, and municipal wells are available from which hydraulic conductivities can be estimated. Generally, these wells are uncased in the basalt, and estimated hydraulic conductivities represent vertically integrated values over the entire penetration interval in the basalt. Therefore, some hydraulic conductivities may represent only a part of an aquifer at a particular location, whereas others may represent composite hydraulic conductivities over parts of two or more aquifers. Because of the similarity between basalt aquifers in structurally similar areas, this was not considered to be a serious problem.

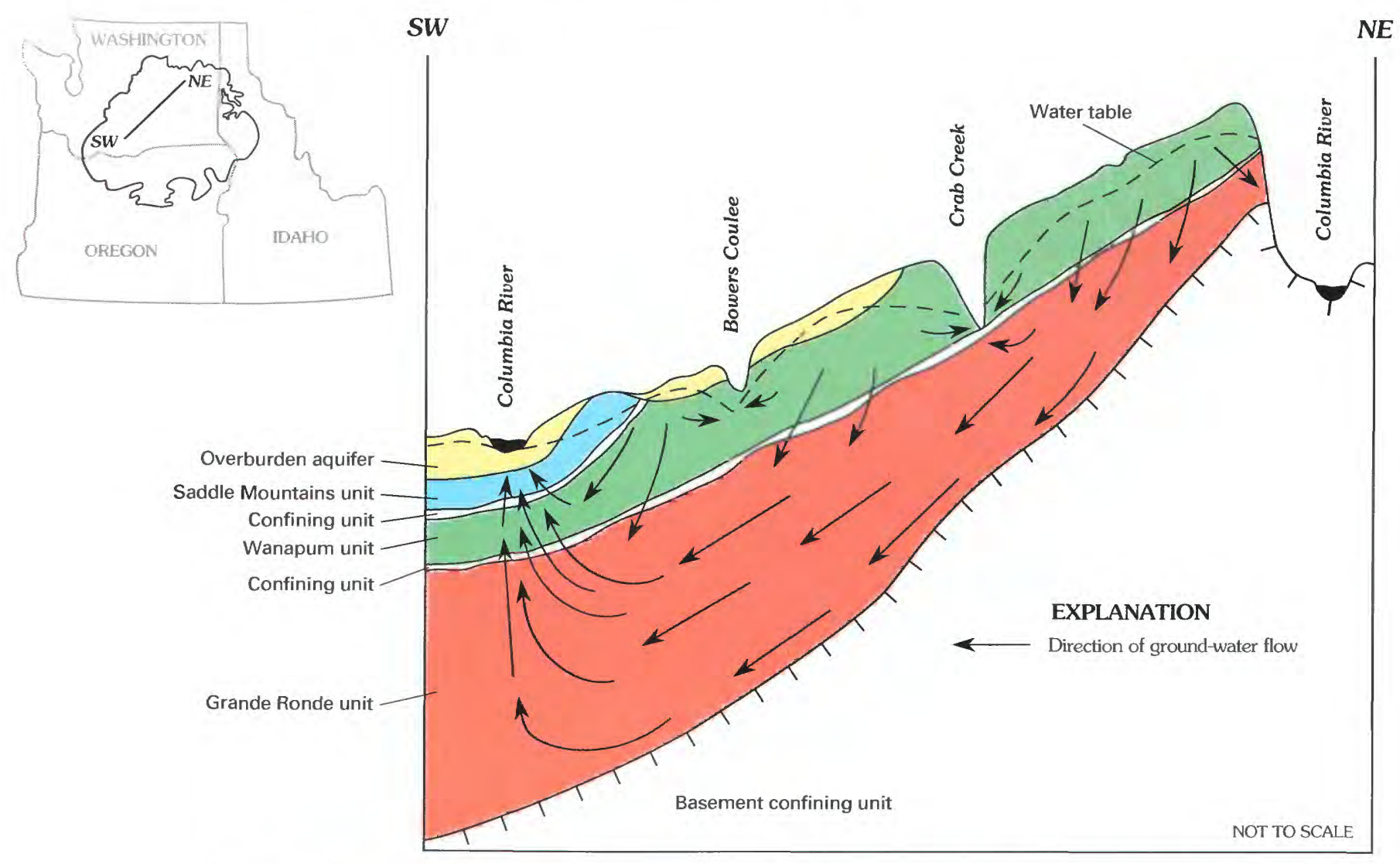

Figure 21.-Generalized ground-water-flow pattern in the Columbia Plateau aquifer system. 
The frequency distribution of the estimated 0.005 to $6,100 \mathrm{ft} / \mathrm{d}$ and have a median of about $5 \mathrm{ft} / \mathrm{d}$. lateral hydraulic conductivities for the three basalt Seventy-five percent of the hydraulic conductivity units is shown in figure 25. The values range from values are less than about $26 \mathrm{ft} / \mathrm{d}$, and 25 percent

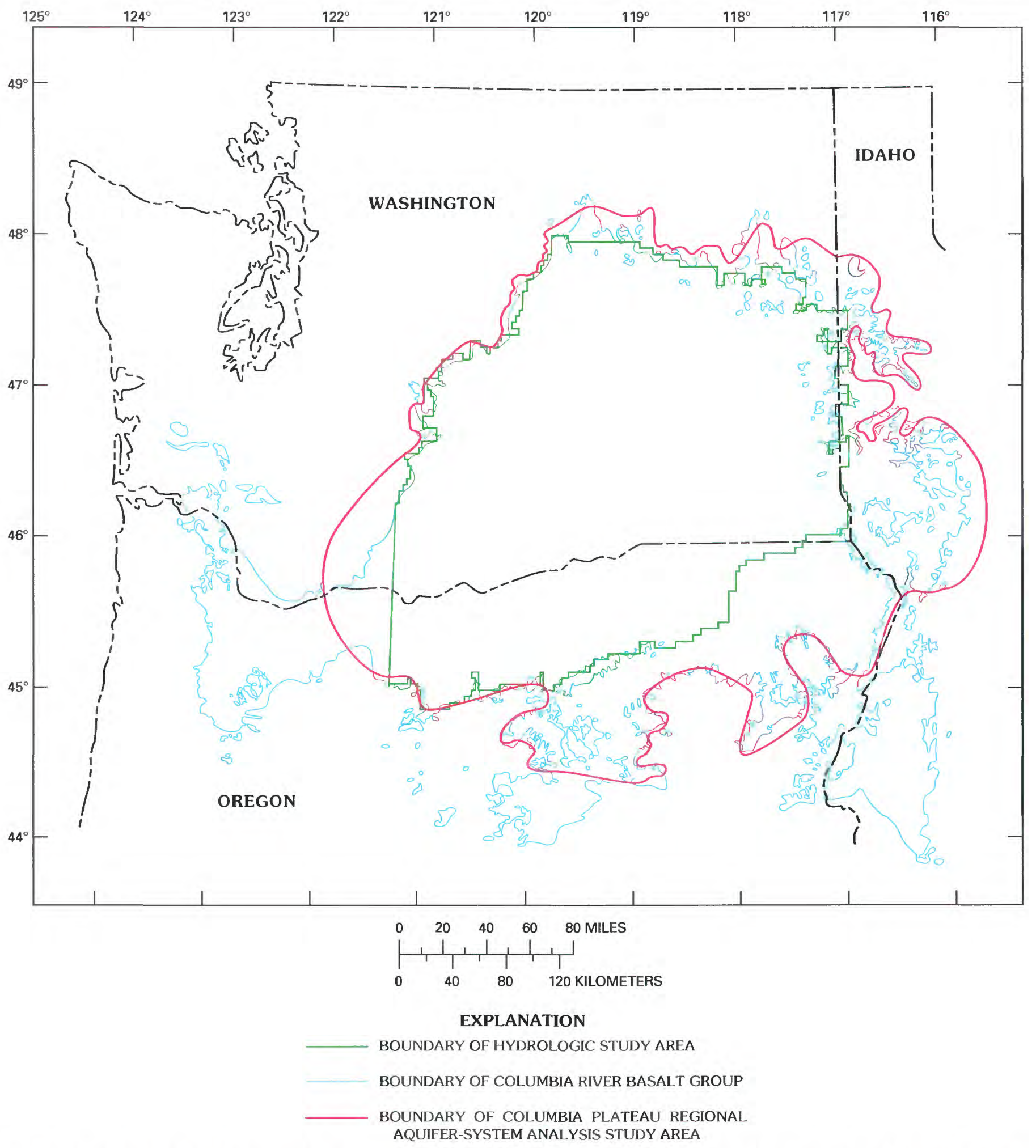

Figure 22.-Relation of the hydrologic study area, the areal extent of the Columbia River Basalt Group, and the Columbia Plateau Regional Aquifer-System Analysis study area. 
are less than about $1 \mathrm{ft} / \mathrm{d}$. The Saddle Mountains, Wanapum, and Grande Ronde units have median hydraulic-conductivity values of $2.4,5.2$, and $4.9 \mathrm{ft} / \mathrm{d}$, respectively. The smaller median hydraulic conductivity of the Saddle Mountains unit is attributed to the thicker and more numerous intercalated sediments, which are generally not present in the Wanapum and Grande Ronde units. In the center of the plateau, these sediments are generally fine grained and less permeable.

The wide range in lateral hydraulic conductivity reflects the heterogeneous nature of the basalts. The largest estimated hydraulic conductivities probably are due to local geologic structure, to thickening of interflow zones, or to the presence of pillow-palagonite complexes (Swanson, 1967). Many wells with large hydraulic-conductivity values are close to wells from which small values were estimated. This indicates the high degree of heterogeneity in the hydraulic conductivity. Observed physical variations in exposed flows indicate that, within a single flow, a wide range of lateral (and vertical) hydraulic-conductivity values would exist. For example, cascading water in many uncased wells is attributed to the relative ease with which water moves horizontally along interflow zones. Thus, the water flows from a higher head interflow zone to a lower head interflow zone through the borehole of a well. The hydraulic conductivity in interflows is probably dependent on primary features such as flow breccia, clinkers, and vesicles, whereas in the entablature and colonnade the hydraulic conductivity is mainly due to fractures and joint systems developed during cooling processes and tectonic activity. Lateral hydraulic conductivity may be much larger than estimated from specific-capacity data for some zones because these estimates represent the entire uncased penetrated intervals.

Lateral hydraulic conductivity of basalts also may be affected by faults. Recent modeling studies (William Meyer, U.S. Geological Survey, written commun., 1985; F.A. Packard, U.S. Geological Survey, written commun., 1987; Davies-Smith and others, 1988) indicate that within a hydrogeologic unit of basalt the vertically averaged lateral hydraulic conductivity along faults might be as low as $0.003 \mathrm{ft} / \mathrm{d}$. There are two possible explanations for this-the offsetting of interflow zones through faulting, which produces low-hydraulic-conductivity fault breccia and gouge material at that interface, as described by Stearns (1942) and Newcomb (1965, 1969); and the closing of pore space through deposition of secondary minerals along the fault plane.

\section{EXPLANATION}
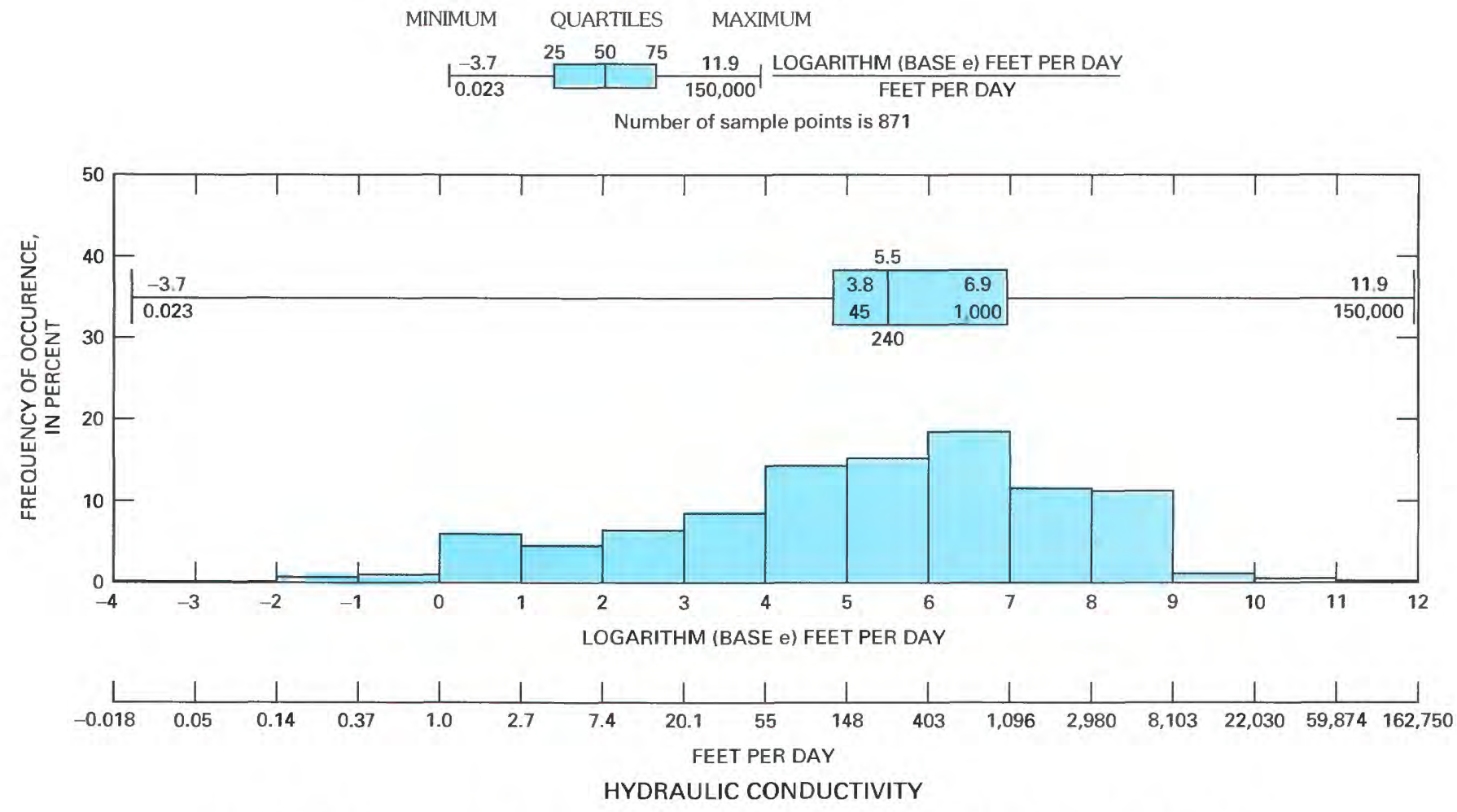

FIGURE 23.-Frequency distribution of hydraulic-conductivity data for the overburden aquifer. 


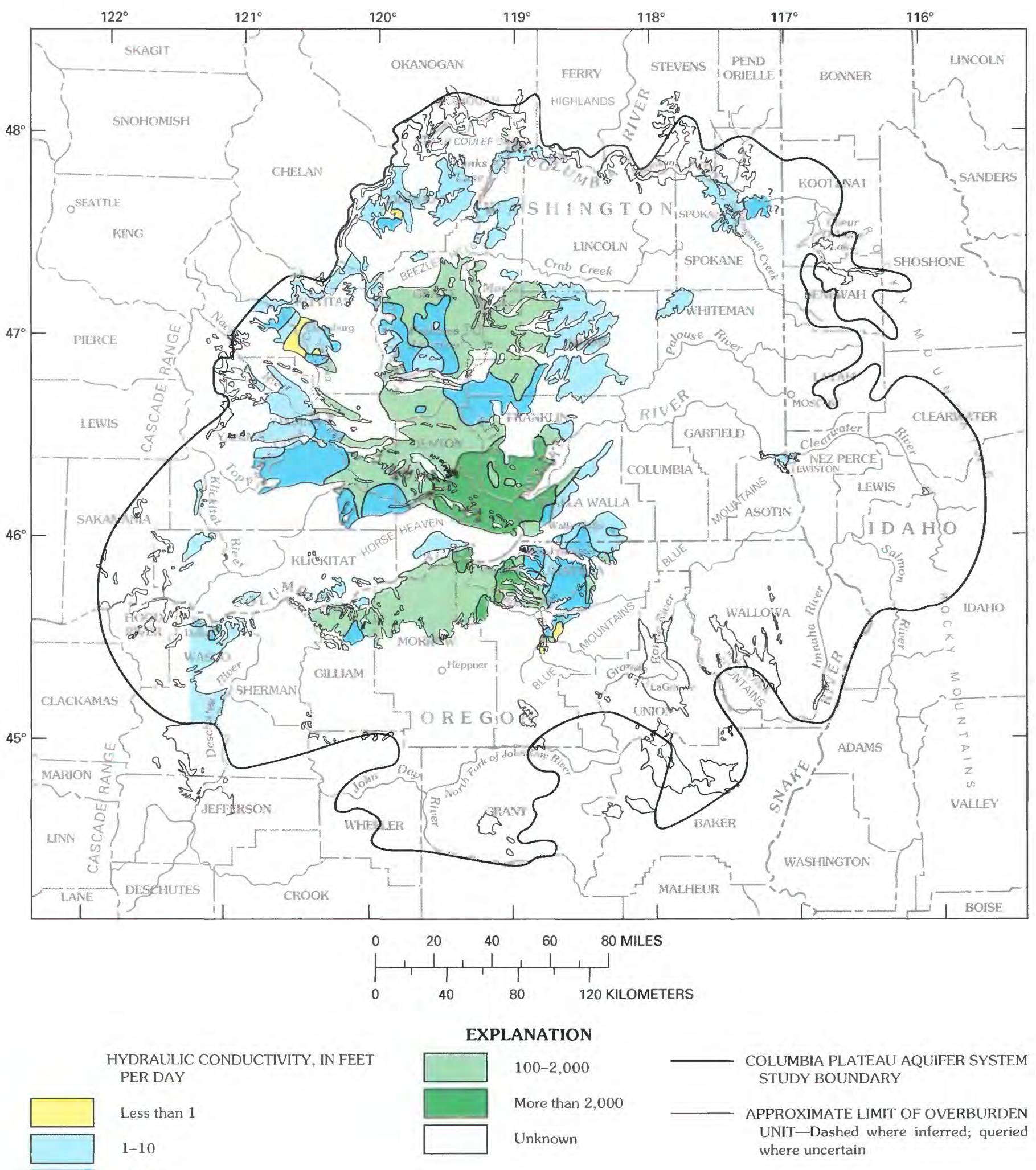

$10-100$

FIgURE 24,-Areal distribution of hydraulic conductivity for the overburden aquifer. 
Large local variation in lateral hydraulic conductivities and the lack of data in many areas preclude areal mapping of these estimated hydraulic conductivities of the basalt units. Results from previous modeling studies (Luzier and Skrivan, 1975; Bolke and Skrivan, 1981; Davies-Smith and others, 1988) indicate that small values of hydraulic conductivity probably are the principal factor controlling the regional movement of ground water in the basalts.

The potential range in transmissivity values can be estimated by using the distribution of thickness of the aquifer system and the estimated hydraulicconductivity values. The frequency distribution of the entire thickness of the Columbia Plateau aquifer system is shown in figure 26. The thickness values were determined on the basis of grid-block sizes of 2.5 minutes of latitude (about $2.8 \mathrm{mi}$ ) by 2.0 minutes of longitude (about $1.6 \mathrm{mi}$ ). The area of each grid block is about $4.6 \mathrm{mi}^{2}$. Application of the grid-determining procedure is to smooth local variation to produce a spatially averaged distribution of the aquifer thickness. Multiplying the minimum, median, and maximum values of aquifer thickness by the respective minimum, median, and maximum values of hydraulic conductivity gives a potential range in values and an approximate median value of the transmissivity of the aquifer

EXPLANATION
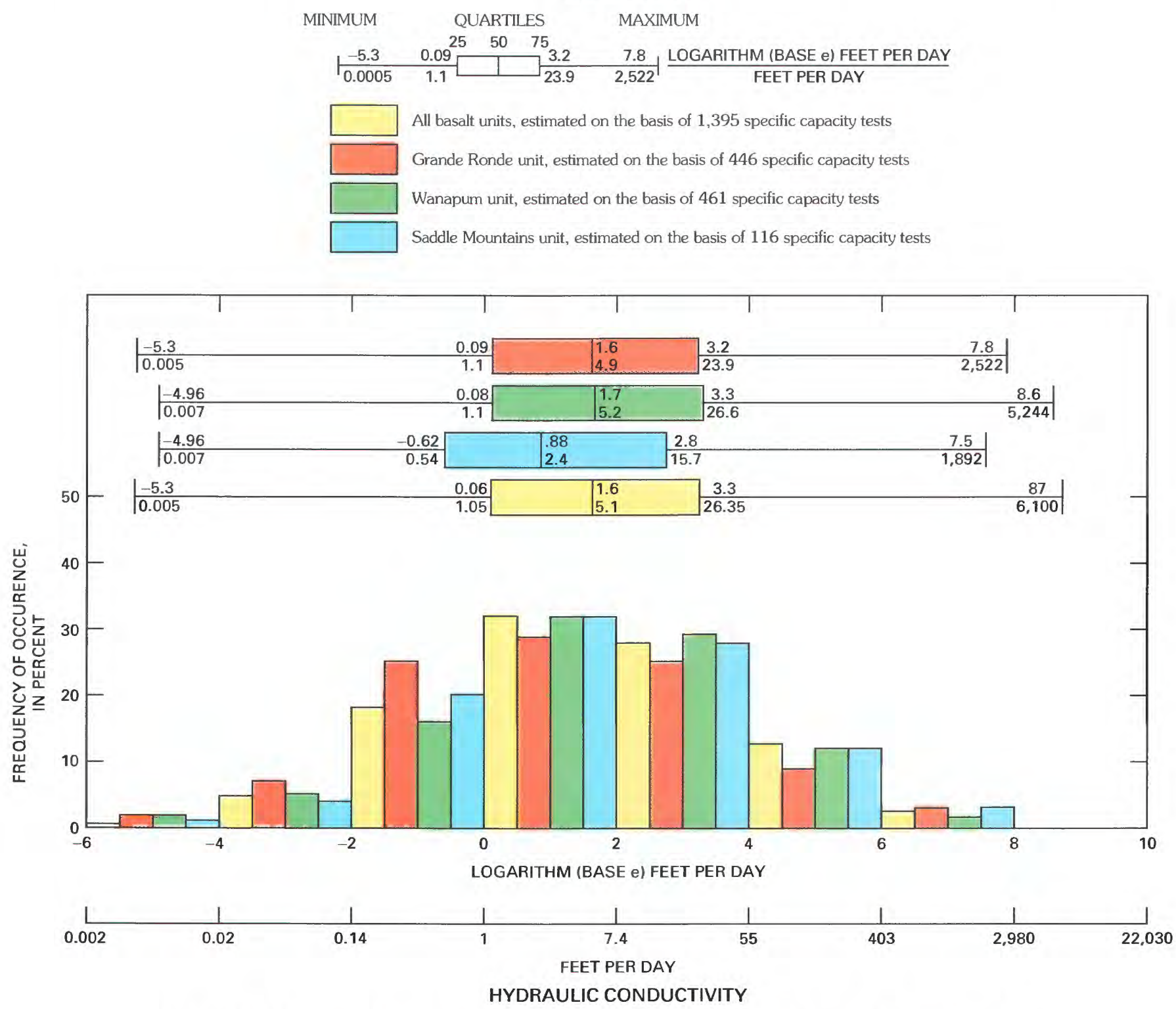

FIGURE 25.-Frequency distribution of lateral hydraulic conductivities for the three basalt units. 
system. The potential range of transmissivities is from 0.5 to 114 million $\mathrm{ft}^{2} / \mathrm{d}$ (feet squared per day), with an approximate median of about $17,000 \mathrm{ft}^{2} / \mathrm{d}$.

Vertical hydraulic-conductivity values of the basalt study units are largely unknown. Estimates made during numerical ground-water-modeling studies (MacNish and Barker, 1976, p. 5; Prych, 1983, p. 35; F.A. Packard, U.S. Geological Survey, written commun., 1987) range from $0.5 \times 10^{-3}$ to $3.5 \mathrm{ft} / \mathrm{d}$, depending on the degree of fracturing and on the presence of pillow-palagonite complexes (Swanson, 1967) or geologic structures. The ratio of horizontal to vertical hydraulic conductivity has been estimated to be about 1,000:1 to 100:1 (W.E. Lum, U.S. Geological Survey, written commun., 1986; A.J. Hansen, U.S. Geological Survey, written commun., 1986; F.A. Packard, U.S. Geological Survey, written commun., 1987).

Storage coefficients were not directly estimated because of the lack of data and the nature of the basalts. However, the potential range of storage coefficients of the three basalt units was estimated on the basis of the specific storage $\left(S_{s}\right)$.

The specific storage $\left(S_{s}\right)$ was described by Jacob (1940) on the basis of the assumption that if the compressibility of the skeleton of the aquifer is small in comparison with the expansibility of water, then the Jacob concept can be described by the following equation:

$$
S_{s}=\theta \gamma / E_{w} \text { or }=\theta \gamma \beta
$$

where $\theta$ is the porosity, $\gamma$ is the specific weight of water, $E_{w}$ is the bulk modulus of elasticity of water, and $\beta$ is the compressibility of water $\left(1 / E_{w}\right)$. Using a value of porosity of 0.04 (previously discussed in the "Basalt Rock Mechanics" section), the compressibility of water of $3.3 \times 10^{-6} \mathrm{in}^{2} / \mathrm{lb}$, and specific weight of water of $0.434 \mathrm{lb}_{\mathrm{in}} .^{-2} \mathrm{ft}^{-1}$, the specific storage was calculated to be $6 \times 10^{-8} \mathrm{ft}^{-1}$.

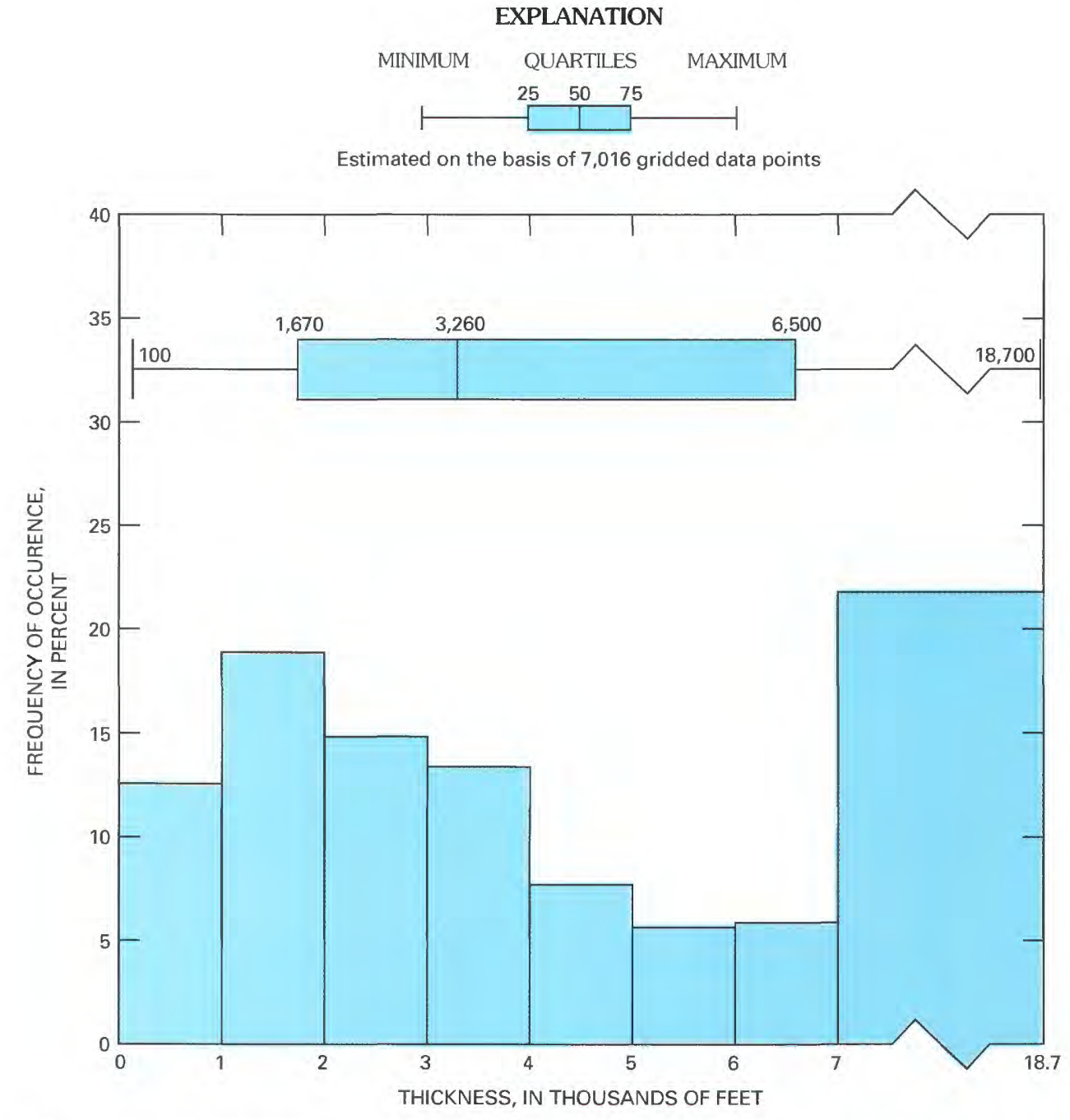

Figure 26,-Frequency distribution of thickness of the Columbia Plateau aquifer system. 
The storage coefficient of each basalt unit was then estimated by multiplying specific storage by the estimates of the unit's thickness (fig. 27). The estimated minimum, median, and maximum values of storage coefficient of each basalt unit are summarized below.

$\begin{array}{lccc} & & \text { Storage coefficient } & \\ \text { Basalt unit } & \text { Minimum } & \text { Median } & \text { Maximum } \\ \text { Saddle Mountains ...... } & \mathbf{1 . 2 \times 1 0 ^ { - 6 }} & 2.2 \times 10^{-5} & 7.8 \times 10^{-5} \\ \text { Wanapum .................... } & \mathbf{1 . 8 \times 1 0 ^ { - 6 }} & 3.2 \times 10^{-5} & 9.9 \times 10^{-5} \\ \text { Grande Ronde ............ } & 6.0 \times 10^{-6} & 1.8 \times 10^{-4} & 1.1 \times 10^{-3}\end{array}$

These estimated values are within the range of storage coefficients estimated by other investigators, which are summarized in table 5 . The overburden aquifer, being a water-table aquifer, has a specific yield that ranges from 0.0002 to 0.2 , as determined from aquifer tests and model simulations (table 5).

\section{RECHARGE AND DISCHARGE}

Recharge to the aquifer system is primarily from precipitation and applied irrigation water, and secondarily from surface-water bodies, such as canals, rivers, and reservoirs. Discharge from the aquifer system, excluding pumpage, is mainly to the river systems and, in lesser quantities, to springs and seeps along canyon and coulee walls and by evapotranspiration. It is difficult to determine the actual discharge to rivers because of the large streamflow, numerous impoundments, and streamflow regulation. This, in turn, makes any analysis of groundwater recharge based on streamflow measurements tenuous and subject to large errors. Recharge is also controlled by both daily and annual climatic variations and, thus, is highly variable both temporally and spatially. The areal variation in recharge

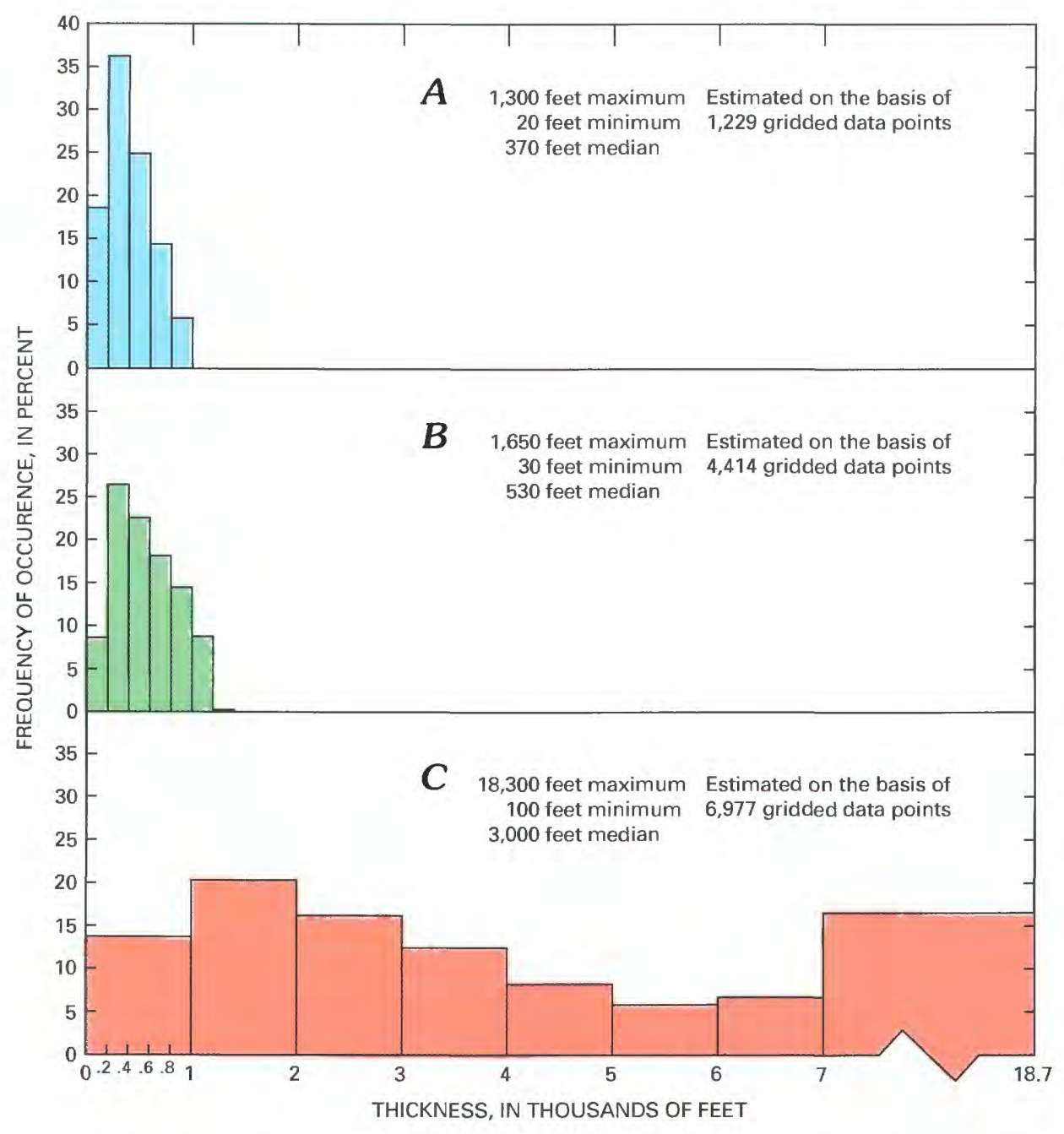

Figure 27.-Frequency distribution of thickness for the (A) Saddle Mountains unit, $(B)$ Wanapum unit, and $(C)$ Grande Ronde unit. 
TABLE 5.-Summary of selected estimates of storage coefficient for the Columbia Plateau aquifer system

\begin{tabular}{|c|c|c|c|c|}
\hline Geologic unit & Hydrogeologic unit & $\begin{array}{l}\text { Storage coefficient } \\
\text { or specific yield }\end{array}$ & $\begin{array}{l}\text { Method }^{1} \text { of } \\
\text { determination }\end{array}$ & References \\
\hline Fluvial & Overburden aquifer & 0.20 & Model & Bolke and Skrivan, 1981 \\
\hline Glaciofluvial & 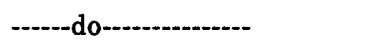 & $0.03-0.2$ & $\mathbf{A T}$ & Newcomb and others, 1972 \\
\hline Ringold Formation & 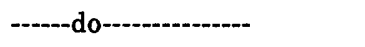 & 0.0002 & AT & Do. \\
\hline Touchet Beds & - & 0.1 & Model & Prych, 1983 \\
\hline Glaciofluvial & 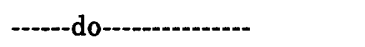 & $0.06-0.2$ & AT & Bierschenk, 1959 \\
\hline Overburden & 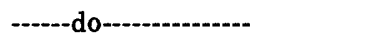 & 0.06 & AT & Do. \\
\hline Ringold Formation & - & 0.1 & AT, Model & Tanaka and others, 1974 \\
\hline Glaciofluvial & 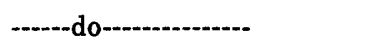 & 0.15 & AT, Model & Do. \\
\hline Basalt & Wanapum unit & $\begin{array}{l}1.2 \times 10^{-4} \\
2.2 \times 10^{-5}\end{array}$ & AT & $\begin{array}{l}\text { Eddy, } 1976 \\
\text { Do. }\end{array}$ \\
\hline Basalt & $\begin{array}{l}\text { Composite Saddle } \\
\text { Mountains unit and } \\
\text { Wanapum unit } \\
\text { Grande Ronde unit }\end{array}$ & $3.2 \times 10^{-2}$ & Model & $\begin{array}{l}\text { A. Smith, U.S. Geological Survey, written } \\
\text { commun., } 1984 \\
\text { Do. }\end{array}$ \\
\hline Basalt & Mainly Wanapum unit & $\begin{array}{l}4.7 \times 10^{-4} \\
9.0 \times 10^{-5} \\
4.75 \times 10^{-3}\end{array}$ & $\mathrm{AT}$ & MacNish and Barker, 1976 \\
\hline Basalt & Wanapum unit & $2.0 \times 10^{-4}$ & AT & Price, 1960 \\
\hline Basalt & $\begin{array}{l}\text { Wanapum unit and } \\
\text { Grande Ronde unit }\end{array}$ & $\begin{array}{l}6 \times 10^{-4} \\
1.4 \times 10^{-6}\end{array}$ & $\mathrm{AT}$ & LaSala and Doty, 1971 \\
\hline Basalt & $\begin{array}{l}\text { Composite of Wanapum } \\
\text { unit and Grande Ronde } \\
\text { unit }\end{array}$ & $\begin{array}{l}1.5 \times 10^{-3} \\
2.0 \times 10^{-3} \\
6.0 \times 10^{-3}\end{array}$ & Model & Luzier and Skrivan, 1975 \\
\hline Basalt & $\begin{array}{l}\text { Saddle Mountains unit, } \\
\text { Wanapum unit, and } \\
\text { Grande Ronde unit }\end{array}$ & $\begin{array}{l}1.0 \times 10^{-2} \\
1.0 \times 10^{-3}\end{array}$ & Model & $\begin{array}{l}\text { F.A. Packard, U.S. Geological Survey, } \\
\text { written commun., } 1987\end{array}$ \\
\hline Basalt & Saddle Mountains unit & $2.5 \times 10^{-3}$ & AT, Model & Tanaka and others, 1974 \\
\hline Basalt & Not determined & $\begin{array}{l}3.1 \times 10^{-2} \\
1.9 \times 10^{-3} \\
4.6 \times 10^{-4} \\
5.0 \times 10^{-5}\end{array}$ & AT & $\begin{array}{l}\text { Oregon Water Resources Department, from } \\
\text { A. Smith, U.S. Geological Survey, written } \\
\text { commun., } 1984\end{array}$ \\
\hline Basalt & $\begin{array}{l}\text { Wanapum unit and } \\
\text { Grande Ronde unit }\end{array}$ & $\begin{array}{l}7.6 \times 10^{-4} \\
\text { to } \\
3.0 \times 10^{-5}\end{array}$ & AT & Tanaka and others, 1979 \\
\hline
\end{tabular}

${ }^{1}$ Model, derived from numerical ground-water model; AT, derived from aquifer tests.

is an important factor in understanding the movement of water in the aquifer system.

Recharge was estimated on a daily basis for 53 basins or zones in the study area by applying a model that computes daily values of deep percolation of water below the effective root zone (Bauer and Vaccaro, 1990). These daily estimates were used to estimate long-term recharge for both predevelopment (1850's) and current land-use conditions (a 1980's multiyear composite). The period of record used to estimate recharge for most of the basins or zones was the 22-yr period from 1956 to 1977 , a period that exhibited climatic variation.

The deep-percolation model is an energy-soilwater balance model developed during the study and is documented in a report by Bauer and Vaccaro (1987). The conceptual models of the energy balance for evapotranspiration and the water balance used in the deep-percolation model are shown in figures 28 and 29. The model is used to compute deep percolation for each control volume or cell into which a zone is discretized. The cell includes vegetation covering the land surface down to the maximum prevalent root depth or, in the case of areas devoid of vegetation, the soil cover down to $5 \mathrm{ft}$ or the total depth of the soil, whichever is less. The root zone or soil cover is divided into 6-in. layers, each with unique physical characteristics. The daily water budget is expressed as 


$$
\begin{aligned}
P R C P= & R O+E V I N T+E V S M+E V S N W+P T R+ \\
& R E C H+\Delta I N T+\Delta S N W+\Delta S M,
\end{aligned}
$$

where

$$
\begin{aligned}
P R C P & =\text { precipitation and irrigation } \\
R O & =\text { surface runoff, } \\
E V I N T & =\text { evaporation of moisture on the foliage } \\
E V S M & =\text { surface } \\
E V S N W & =\text { evaporation from bare soil, } \\
P T R & =\text { transpiration, } \\
R E C H & =\text { water percolating beyond the root zone } \\
\Delta I N T & =\text { change of moisture on the foliage surface } \\
\Delta S N W & =\text { change of snowpack, and } \\
\Delta S M & =\text { change of soil water in the root zone. }
\end{aligned}
$$

The following data are required for each modeled zone to estimate recharge: daily streamflows, estimates of monthly base flow, daily precipitation, and maximum and minimum daily air temperatures. For each cell the following data are required: 22 -yr average annual values of precipitation, mean monthly maximum and minimum air-temperature lapse rates (a lapse rate is a temperature change with altitude), soil water-holding capacity, soil texture, topographic data (altitude-slope-aspect), landuse classification, and annual application rates of irrigation water.

Daily meteorological data were obtained from the U.S. Department of Commerce for 103 weather sites, 89 of which included daily air-temperature data (see fig. 4 and tables 1 and 2). A 22-yr average annual precipitation map for the period 195677 was developed for the study by Nelson (1991) and is shown in figure 2. Regional monthly maximum and minimum air-temperature lapse rates were estimated by Bauer and Vaccaro (1990). Soil information was obtained from the U.S. Soil Conservation Service county soil maps. The various soil-type data were aggregated by physical characteristics into 24 soil categories. Slope and aspect for cells were computed from altitude data obtained from the U.S. Geological Survey as Digital Elevation Model (DEM) (Elassal and Caruso, 1983). Land-use classification data for 1975 (fig. 30) initially were obtained from T.A. Zimmerman (Battelle Northwest Laboratory, written commun., 1984) and later were modified on the basis of Landsat data by Wukelic and others (1981). On the basis of information presented by Wukelic and others (1981) for 1979 and of field and map identification of irrigated croplands by D.R. Cline, M.E. Knadle, and C.A. Collins (U.S. Geological Survey, written commun., 1986) for the period 1983 to 1985 , additional irrigated lands were added to the irrigated lands shown in figure 30. Predevelopment land-use conditions were estimated from these data by assuming that, historically, dryland croplands were grasslands, irrigated croplands were sagebrush, and residential-commercial-urban development was sagebrush. Surface-water irrigation rates

\section{EVAPOTRANSPIRATION}

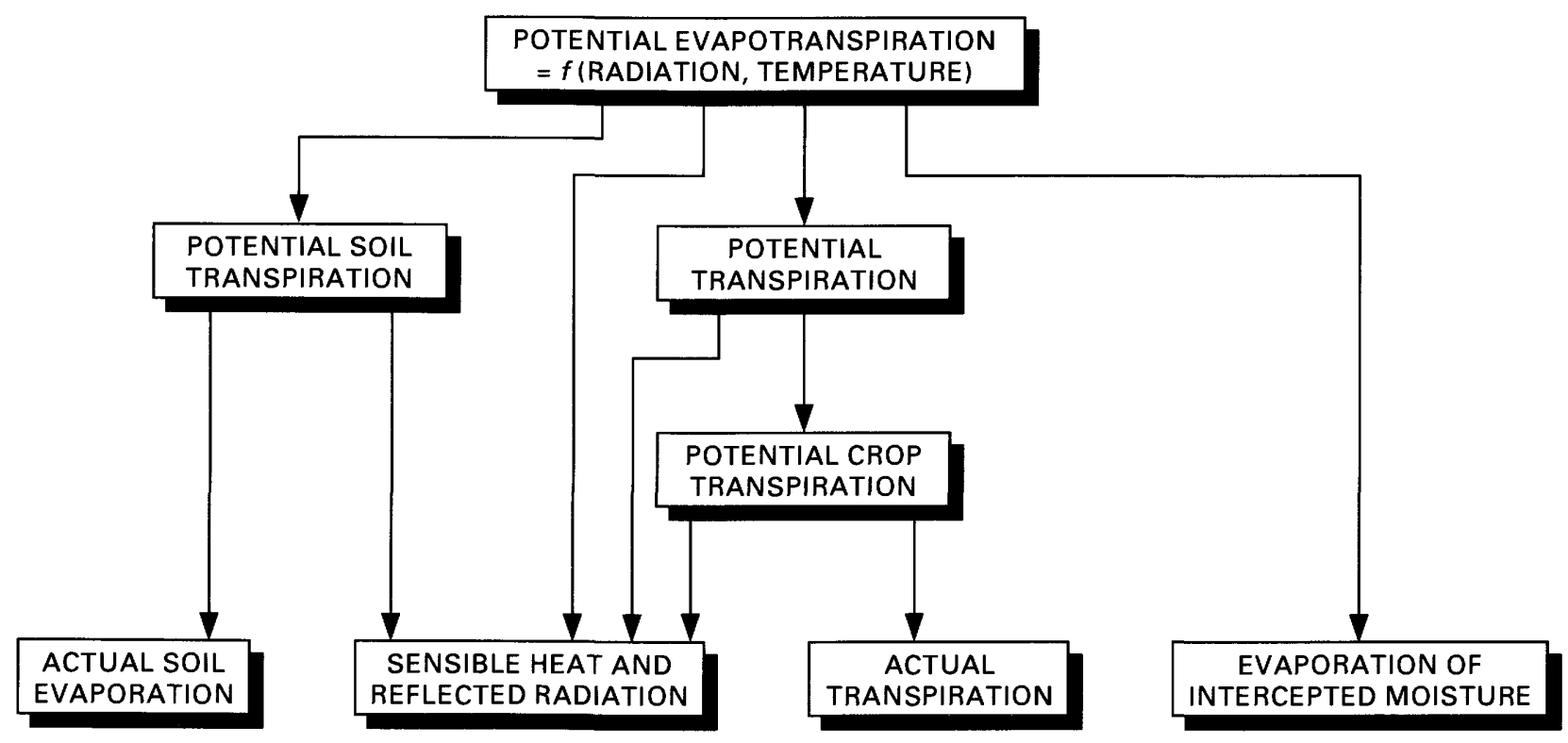

FIGURE 28.-Schematic diagram showing the conceptual model of the energy balance for evapotranspiration (from Bauer and Vaccaro, 1987). 
were based on data from Washington State Department of Ecology (1974) and ground-water-irrigation rates were reported by D.R. Cline, M.E. Knadle, and C.A. Collins (U.S. Geological Survey, written commun., 1985). A detailed description and analysis of the data can be found in Bauer and Vaccaro (1990).

The estimates of recharge in each of the 53 selected basins calculated by the deep-percolation model are shown in figure 31 . Fifty basins were discretized into rectangular cells with cell areas ranging from $0.25 \mathrm{mi}^{2}$ to $1.2 \mathrm{mi}^{2}$. The remaining three basins were discretized with highly variable cell sizes. The estimated recharge for each cell then was integrated into the $4.6-\mathrm{mi}^{2}$ blocks discussed in the "Hydraulic Characteristics" section. Estimates of recharge for the remaining study area not included in the 53 basins were made by using a polynomial regression equation. The regression equation relates the 22 -yr average annual precipitation to the estimated recharge modeled for the 53 selected basins. The 22-yr average annual precipitation values were interpolated to the remaining study area using digitized annual precipitation contours and a surface-fitting technique described in IMSL (1982). On the basis of the polynomial regression equation

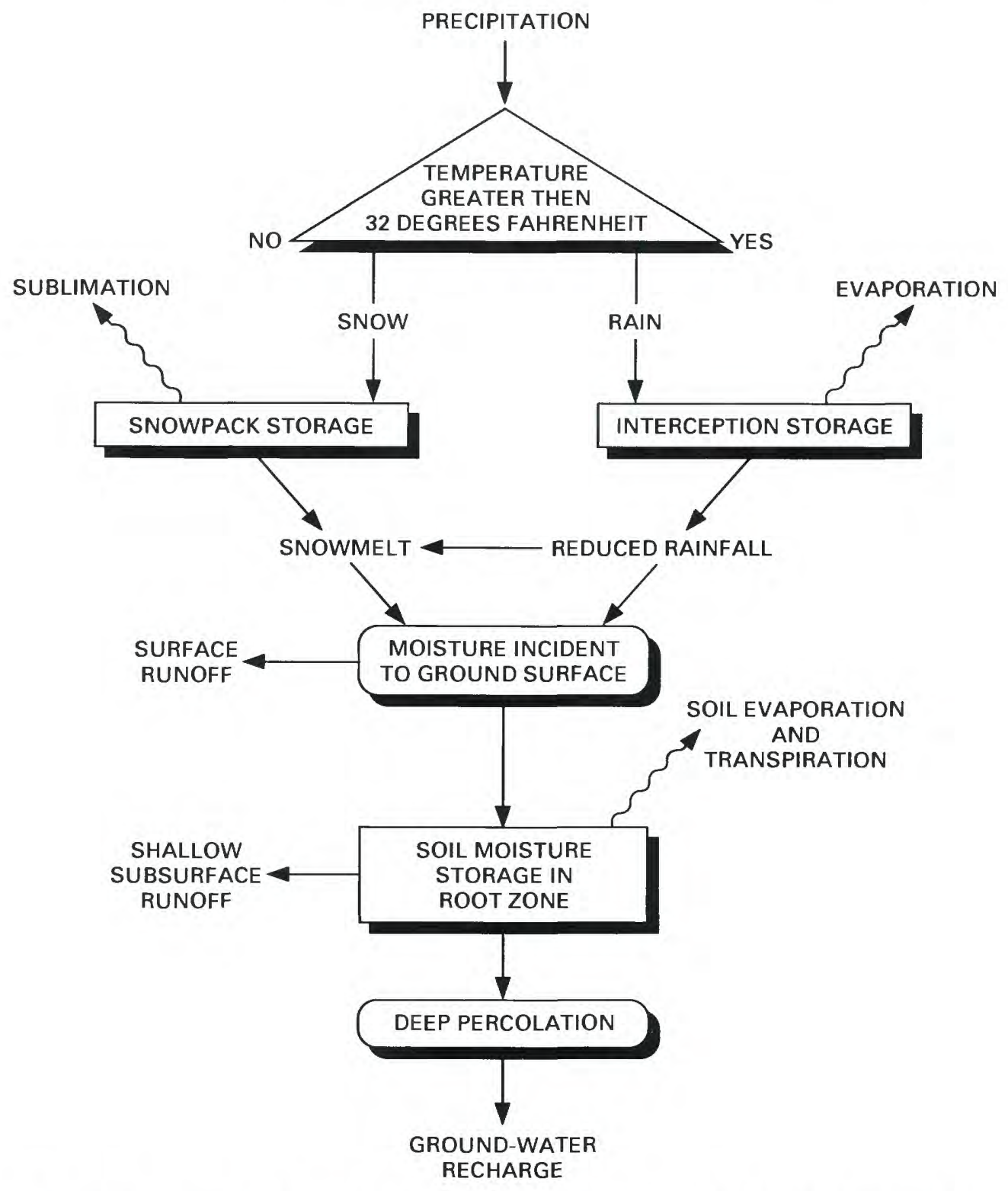

Figure 29.-Schematic diagram showing the conceptual model of the water balance used in the deep-percolation model (from Bauer and Vaccaro, 1987). 

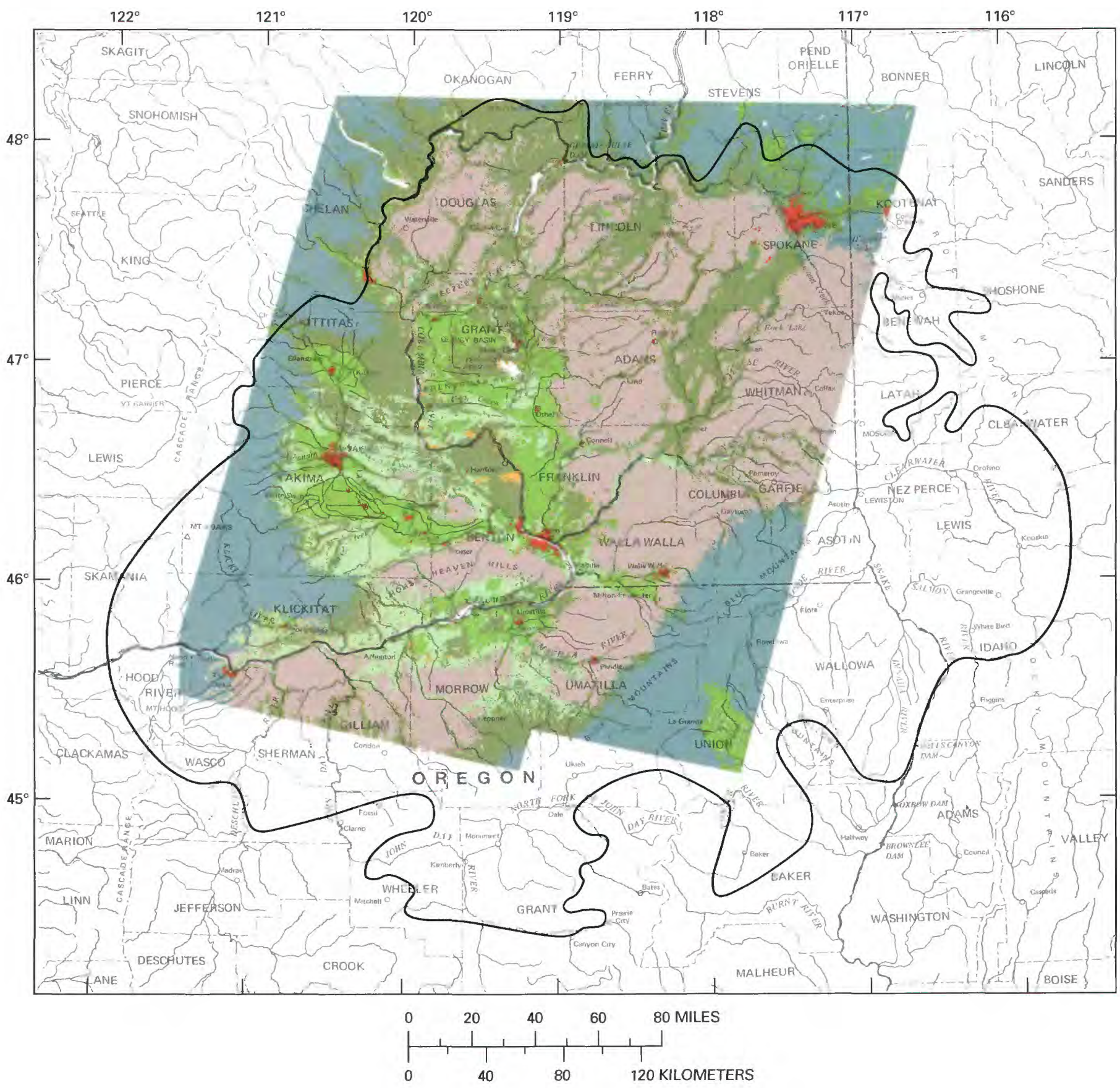

EXPLANATION

AREA, IN SQUARE MILES

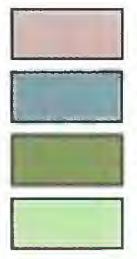

12,015
10,332
9,887
3,930

AREA, IN SQUARE MILES

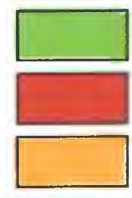

IRRIGATED AGRICULTURE

3,366

COMMERCIAL/RESIDENTIAL

216

SAND/BARREN

197

COLUMBIA PLATEAU AQUIFER SYSTEM STUDY BOUNDARY

Figure 30.-Land-use classification of the Columbia Plateau, 1975 (from Wukelic and others, 1981, and from Bauer and Vaccaro, 1990). 
and the interpolated annual precipitation values, recharge values for the remaining study area then were estimated. The resulting distributions of esti- $\mid$ tions are shown in figures 32 and 33, respectively.
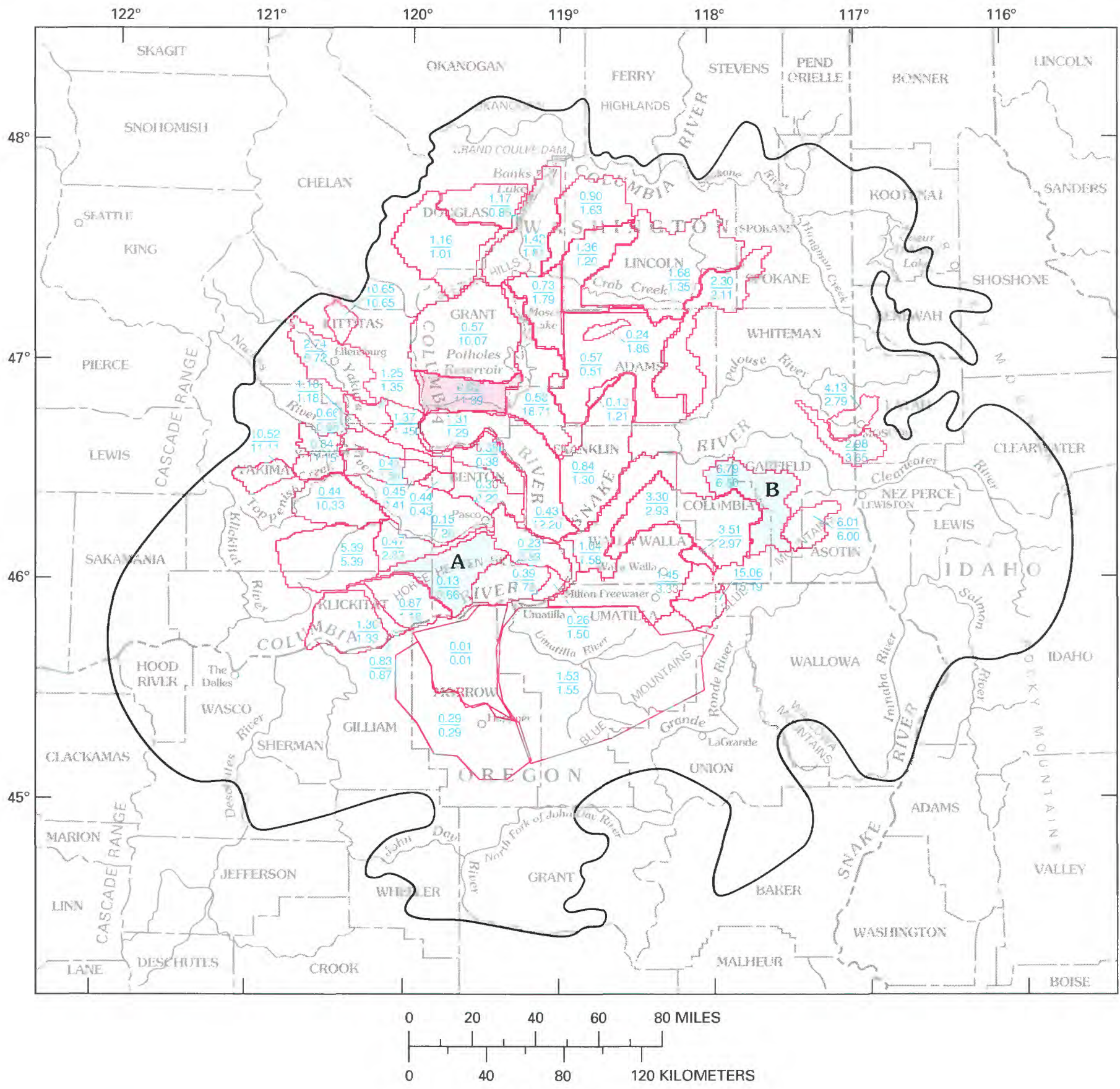

EXPLANATION

ESTIMATE OF AVERAGE RECHARGE. IN INCHES PER YEAR - Upper number is predevelopment (1850's); lower number is current (1980's)

A,B WATER BUDGET FOR ZONES A AND B SHOWN IN TABLE 6

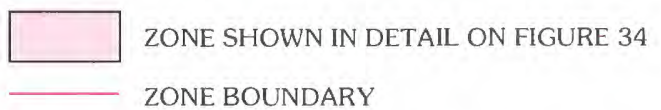

ZONE BOUNDARY

COLUMBIA PLATEAU AQUIFER SYSTEM STUDY BOUNDARY

Figure 31.-Estimates of recharge in each of 53 selected basins (from Bauer and Vaccaro, 1990). 

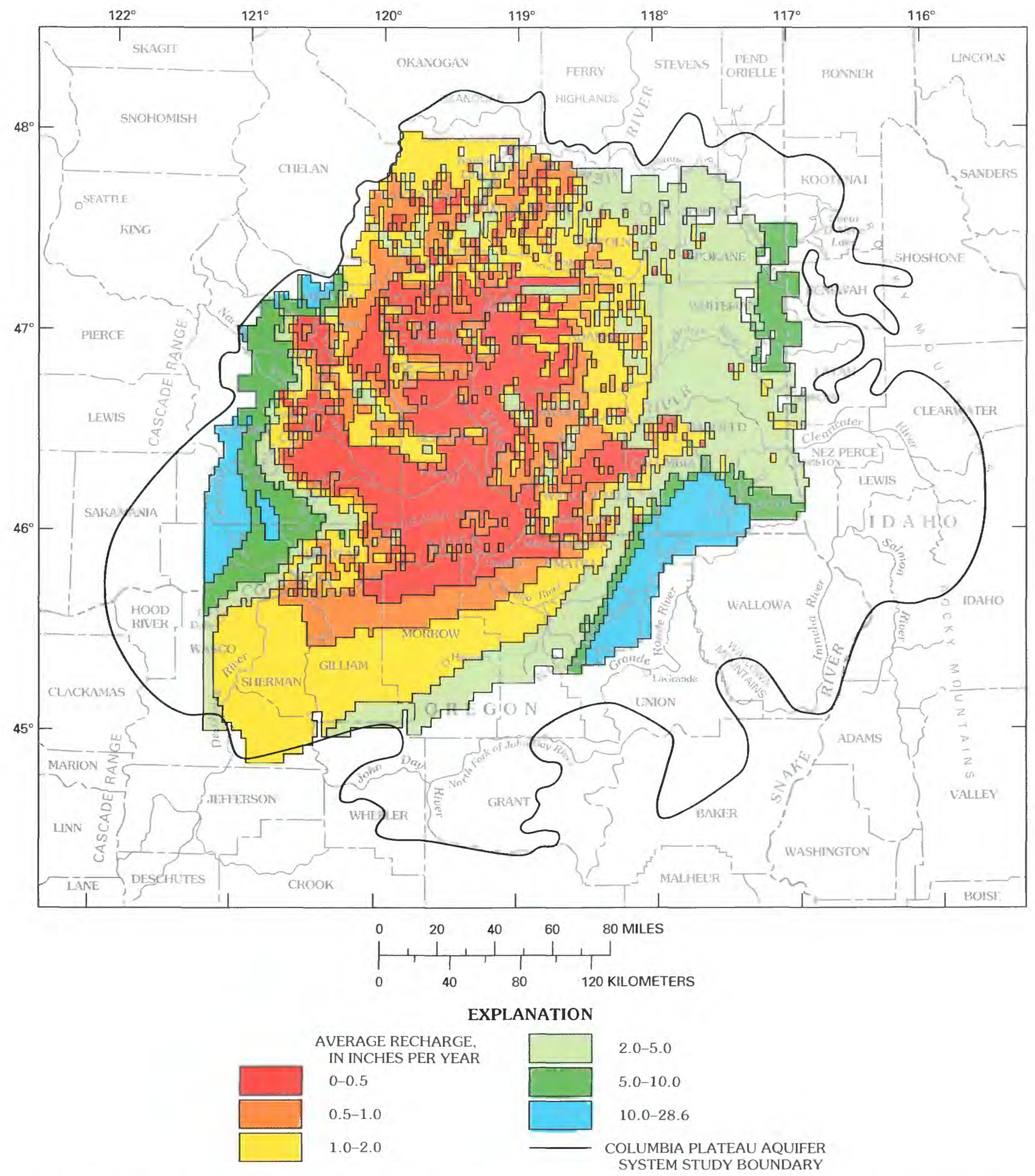

Figure 32-Distribution of estimated recharge under predevelopment (1850's) conditions (from Bauer and Vaccaro, 1990). 

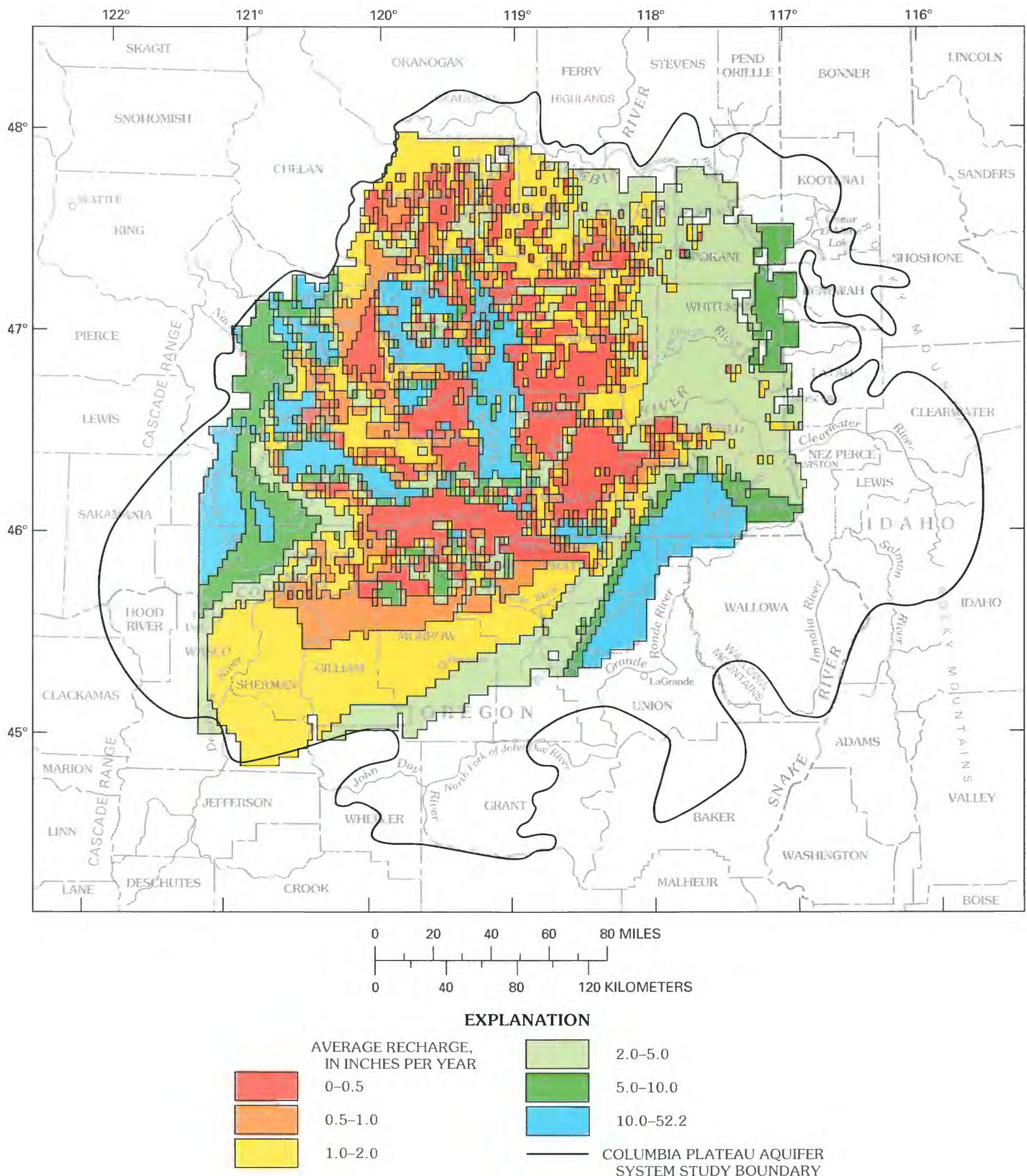

AVERAGE RECHARGE IN INCHES PER YEAR

$0-0.5$

$0.5-1.0$

$1.0-2.0$

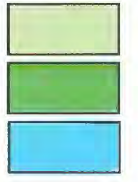

$2.0-5.0$

$5.0-10.0$

$10.0-52.2$

COLUMBIA PLATEAU AQUIFER SYSTEM STUDY BOUNDARY

FIGURE 33-Distribution of estimated recharge under current (1980's) conditions (from Bauer and Vaccaro, 1990). 
TABLE 6.-Computed long-term, averaged monthly water budget for a semiarid (A) and a temperate (B) zone [Values in inches]

\begin{tabular}{|c|c|c|c|c|c|c|c|c|c|c|c|}
\hline \multirow[b]{3}{*}{ Month } & \multirow[b]{3}{*}{ Zone $^{2}$} & \multicolumn{10}{|c|}{ Water-budget component ${ }^{1}$} \\
\hline & & \multirow[b]{2}{*}{$\begin{array}{l}\text { Precipi- } \\
\text { tation }\end{array}$} & \multirow[b]{2}{*}{$\begin{array}{c}\text { Surface }^{3} \\
\text { runoff }\end{array}$} & \multicolumn{3}{|c|}{ Evaporation from: } & \multirow[b]{2}{*}{$\begin{array}{c}\text { Plant } \\
\text { transpiration }\end{array}$} & \multirow[b]{2}{*}{ Recharge } & \multicolumn{3}{|c|}{ Change in: } \\
\hline & & & & $\begin{array}{l}\text { Intercepted } \\
\text { moisture }\end{array}$ & $\begin{array}{l}\text { Bare } \\
\text { soil }\end{array}$ & Snow & & & $\begin{array}{l}\text { Intercepted } \\
\text { moisture }\end{array}$ & Snow & $\begin{array}{c}\text { Soil } \\
\text { moisture }\end{array}$ \\
\hline January & $\begin{array}{l}\mathrm{A} \\
\mathrm{B}\end{array}$ & $\begin{array}{l}1.00 \\
2.85\end{array}$ & $\begin{array}{r}0.04 \\
.48\end{array}$ & $\begin{array}{r}0.18 \\
.21\end{array}$ & $\begin{array}{r}0.11 \\
.06\end{array}$ & $\begin{array}{r}0.07 \\
.13\end{array}$ & $\begin{array}{r}0.04 \\
.02\end{array}$ & $\begin{array}{l}0.07 \\
1.47\end{array}$ & $\begin{array}{l}0.0 \\
-.02\end{array}$ & $\begin{array}{r}-0.05 \\
.06\end{array}$ & $\begin{array}{r}0.54 \\
.44\end{array}$ \\
\hline February & $\begin{array}{l}\mathrm{A} \\
\mathrm{B}\end{array}$ & $\begin{array}{r}.27 \\
1.86\end{array}$ & $\begin{array}{l}.01 \\
.34\end{array}$ & $\begin{array}{l}.11 \\
.35\end{array}$ & $\begin{array}{l}.33 \\
.13\end{array}$ & $\begin{array}{l}.0 \\
.05\end{array}$ & $\begin{array}{l}.26 \\
.09\end{array}$ & $\begin{array}{l}.0 \\
.99\end{array}$ & $\begin{array}{l}.0 \\
.0\end{array}$ & $\begin{array}{l}-.01 \\
-.13\end{array}$ & $\begin{array}{r}-.43 \\
.04\end{array}$ \\
\hline March & $\begin{array}{l}\mathrm{A} \\
\mathrm{B}\end{array}$ & $\begin{array}{r}.29 \\
2.16\end{array}$ & $\begin{array}{l}.01 \\
.30\end{array}$ & $\begin{array}{l}.20 \\
.56\end{array}$ & $\begin{array}{l}.27 \\
.24\end{array}$ & $\begin{array}{l}.0 \\
.05\end{array}$ & $\begin{array}{l}.67 \\
.36\end{array}$ & $\begin{array}{l}.0 \\
.98\end{array}$ & $\begin{array}{l}.0 \\
.0\end{array}$ & $\begin{array}{c}.0 \\
-.12\end{array}$ & $\begin{array}{l}-.86 \\
-.21\end{array}$ \\
\hline April & $\begin{array}{l}\text { A } \\
\text { B }\end{array}$ & $\begin{array}{r}.34 \\
1.53\end{array}$ & $\begin{array}{l}.0 \\
.19\end{array}$ & $\begin{array}{l}.21 \\
.70\end{array}$ & $\begin{array}{l}.02 \\
.26\end{array}$ & $\begin{array}{l}.0 \\
.01\end{array}$ & $\begin{array}{l}.85 \\
.95\end{array}$ & $\begin{array}{l}.0 \\
.37\end{array}$ & $\begin{array}{c}.0 \\
-.03\end{array}$ & $\begin{array}{c}.0 \\
-.06\end{array}$ & $\begin{array}{l}-.74 \\
-.86\end{array}$ \\
\hline May & $\begin{array}{l}\text { A } \\
\text { B }\end{array}$ & $\begin{array}{r}.18 \\
1.56\end{array}$ & $\begin{array}{l}.0 \\
.19\end{array}$ & $\begin{array}{l}.13 \\
.78\end{array}$ & $\begin{array}{l}.0 \\
.15\end{array}$ & $\begin{array}{l}.0 \\
.0\end{array}$ & $\begin{array}{r}.45 \\
1.51\end{array}$ & $\begin{array}{l}.0 \\
.19\end{array}$ & $\begin{array}{c}.0 \\
-.01\end{array}$ & $\begin{array}{l}.0 \\
.0\end{array}$ & $\begin{array}{r}-.40 \\
-1.25\end{array}$ \\
\hline June & $\begin{array}{l}\text { A } \\
\text { B }\end{array}$ & $\begin{array}{r}.69 \\
1.28\end{array}$ & $\begin{array}{l}.0 \\
.12\end{array}$ & $\begin{array}{l}.28 \\
.68\end{array}$ & $\begin{array}{l}.01 \\
.08\end{array}$ & $\begin{array}{l}.0 \\
.0\end{array}$ & $\begin{array}{r}.39 \\
1.04\end{array}$ & $\begin{array}{l}.0 \\
.11\end{array}$ & $\begin{array}{c}.0 \\
-.02\end{array}$ & $\begin{array}{l}.0 \\
.0\end{array}$ & $\begin{array}{r}.01 \\
-.73\end{array}$ \\
\hline July & $\begin{array}{l}\text { A } \\
\text { B }\end{array}$ & $\begin{array}{l}.30 \\
.61\end{array}$ & $\begin{array}{l}.0 \\
.03\end{array}$ & $\begin{array}{l}.13 \\
.33\end{array}$ & $\begin{array}{l}.0 \\
.02\end{array}$ & $\begin{array}{l}.0 \\
.0\end{array}$ & $\begin{array}{l}.21 \\
.53\end{array}$ & $\begin{array}{l}.0 \\
.03\end{array}$ & $\begin{array}{l}.0 \\
.0\end{array}$ & $\begin{array}{l}.0 \\
.0\end{array}$ & $\begin{array}{l}-.04 \\
-.33\end{array}$ \\
\hline August & $\begin{array}{l}\text { A } \\
\text { B }\end{array}$ & $\begin{array}{l}.30 \\
.96\end{array}$ & $\begin{array}{l}.0 \\
.02\end{array}$ & $\begin{array}{l}.20 \\
.47\end{array}$ & $\begin{array}{l}.0 \\
.03\end{array}$ & $\begin{array}{l}.0 \\
.0\end{array}$ & $\begin{array}{l}.05 \\
.29\end{array}$ & $\begin{array}{l}.0 \\
.07\end{array}$ & $\begin{array}{l}.0 \\
.01\end{array}$ & $\begin{array}{l}.0 \\
.0\end{array}$ & $\begin{array}{l}.05 \\
.07\end{array}$ \\
\hline September & $\begin{array}{l}\mathrm{A} \\
\mathrm{B}\end{array}$ & $\begin{array}{r}.22 \\
1.06\end{array}$ & $\begin{array}{l}.0 \\
.02\end{array}$ & $\begin{array}{l}.13 \\
.45\end{array}$ & $\begin{array}{l}.0 \\
.06\end{array}$ & $\begin{array}{l}.0 \\
.0\end{array}$ & $\begin{array}{l}.10 \\
.35\end{array}$ & $\begin{array}{l}.0 \\
.13\end{array}$ & $\begin{array}{l}.0 \\
.0\end{array}$ & $\begin{array}{l}.0 \\
.0\end{array}$ & $\begin{array}{r}-.01 \\
.05\end{array}$ \\
\hline October & $\begin{array}{l}\mathrm{A} \\
\mathrm{B}\end{array}$ & $\begin{array}{r}.55 \\
1.54\end{array}$ & $\begin{array}{l}.0 \\
.03\end{array}$ & $\begin{array}{l}.25 \\
.52\end{array}$ & $\begin{array}{l}.02 \\
.06\end{array}$ & $\begin{array}{l}.0 \\
.0\end{array}$ & $\begin{array}{l}.09 \\
.21\end{array}$ & $\begin{array}{l}.0 \\
.28\end{array}$ & $\begin{array}{l}.0 \\
.05\end{array}$ & $\begin{array}{l}.0 \\
.01\end{array}$ & $\begin{array}{l}.19 \\
.38\end{array}$ \\
\hline November & $\begin{array}{l}\text { A } \\
\text { B }\end{array}$ & $\begin{array}{l}1.55 \\
2.59\end{array}$ & $\begin{array}{l}.01 \\
.09\end{array}$ & $\begin{array}{l}.33 \\
.39\end{array}$ & $\begin{array}{l}.03 \\
.04\end{array}$ & $\begin{array}{l}.0 \\
.03\end{array}$ & $\begin{array}{l}.06 \\
.06\end{array}$ & $\begin{array}{l}.0 \\
.87\end{array}$ & $\begin{array}{l}.02 \\
.03\end{array}$ & $\begin{array}{l}.0 \\
.11\end{array}$ & $\begin{array}{r}1.10 \\
.97\end{array}$ \\
\hline December & $\begin{array}{l}\text { A } \\
\text { B }\end{array}$ & $\begin{array}{l}1.29 \\
3.06\end{array}$ & $\begin{array}{l}.08 \\
.30\end{array}$ & $\begin{array}{l}.16 \\
.23\end{array}$ & $\begin{array}{l}.06 \\
.04\end{array}$ & $\begin{array}{l}.08 \\
.10\end{array}$ & $\begin{array}{l}.03 \\
.01\end{array}$ & $\begin{array}{r}.05 \\
1.33\end{array}$ & $\begin{array}{l}-.01 \\
-.01\end{array}$ & $\begin{array}{l}.13 \\
.17\end{array}$ & $\begin{array}{l}.71 \\
.94\end{array}$ \\
\hline Annual & $\begin{array}{l}\text { A } \\
\text { B }\end{array}$ & $\begin{array}{r}6.98 \\
21.06\end{array}$ & $\begin{array}{r}.15 \\
2.11\end{array}$ & $\begin{array}{l}2.31 \\
5.67\end{array}$ & $\begin{array}{r}.85 \\
1.17\end{array}$ & $\begin{array}{l}.15 \\
.37\end{array}$ & $\begin{array}{l}3.20 \\
5.42\end{array}$ & $\begin{array}{r}.12 \\
6.82\end{array}$ & $\begin{array}{l}.01 \\
.0\end{array}$ & $\begin{array}{l}.07 \\
.04\end{array}$ & $\begin{array}{r}.12 \\
-.49\end{array}$ \\
\hline
\end{tabular}

\footnotetext{
1See "Recharge and Discharge" section for description of budget components.

2 Zones outlined in figure 31 .

${ }^{3}$ Values calculated using estimates of monthly baseflow; values are generally overestimates (larger) due to underestimates of and errors in monthly baseflow estimates. This results in conservative estimates of recharge.
}

The computed long-term, averaged, monthly water budget for a semiarid (A) and temperate (B) zone is shown in table 6 (see fig. 31 for locations). The distribution of recharge under both conditions in an arid zone (see fig. 31 for location) shows the large areal variation in recharge and the effects of irrigation, mainly surface-water irrigation (fig. 34). Recharge was found to be most sensitive to amount of total precipitation and to soil type; sandy-type soils allow for deeper percolation.

The plateau-wide, long-term, averaged estimate of recharge for predevelopment land-use conditions was about $6,000 \mathrm{ft}^{3} / \mathrm{s}$, most of which probably discharged to streams. The estimate of recharge for current land-use conditions is about $9,490 \mathrm{ft}^{3} / \mathrm{s}$. Thus, recharge was increased by about $3,490 \mathrm{ft}^{3} / \mathrm{s}$ as a result of surface-water and ground-water irrigation and additional recharge on fallowed dryland croplands. About 33 percent of the additional recharge $\left(1,144 \mathrm{ft}^{3} / \mathrm{s}\right)$ discharged as ground-water pumpage in 1984 . The remainder, about $2,346 \mathrm{ft}^{3} / \mathrm{s}$, discharged to drains and streams and to the atmosphere as evapotranspiration. As an example of the development effects, some drains in the areas irrigated with surface water receive as much as $80 \mathrm{ft}^{3} / \mathrm{s}$ of additional ground-water discharge, and ephemeral streams in the arid part of the plateau that historically flowed about 6 days a year now flow at least through the irrigation season (Nelson, 1991). One example is Equatzel Coulee, located in central Franklin County, which flows at about $50 \mathrm{ft}^{3} / \mathrm{s}$ during the irrigation season. Discharge as additional evapotranspiration occurs mainly in the Satus and Toppenish River basins and in the Columbia Basin Irrigation Project area, where surface-water irrigation has caused the water levels to be at or near the land surface (Tanaka and others, 1974; Bolke and Skrivan, 1981; Prych, 1983). 

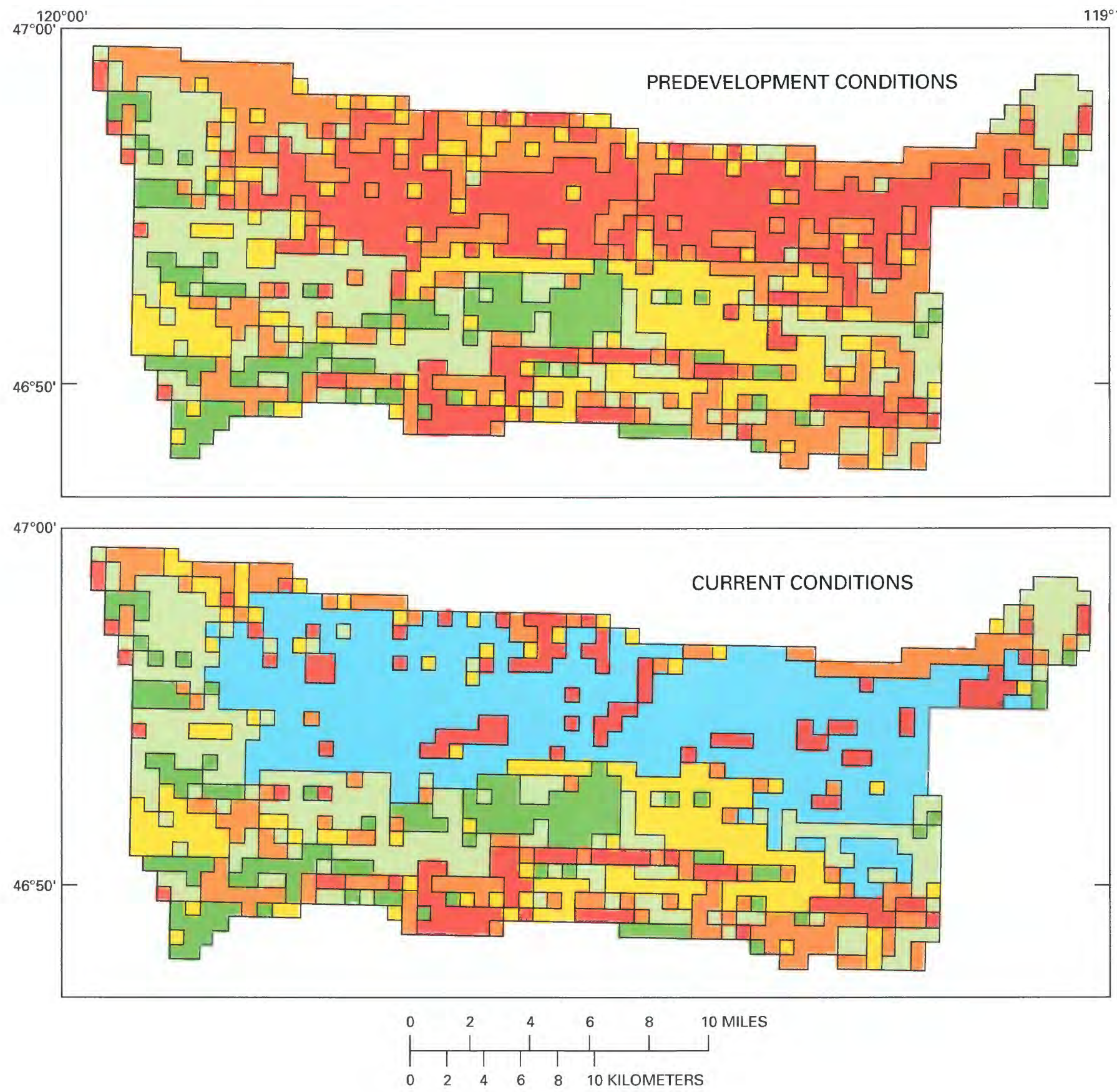

\section{EXPLANATION}

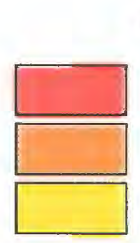

AVERAGE RECHARGE, IN INCHES PER YEAR

0-0.1

$0.1-0.5$

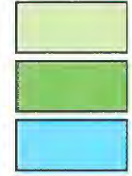

1. $0-2.0$

$2.0-5.0$

$0.5-1.0$

MORE THAN 5.0

Figure 34.-Distribution of estimated recharge under predevelopment (1850's) and current (1980's) conditions in an arid zone. See figure 31 for location of area. 


\section{GROUND-WATER DEVELOPMENT}

Ground-water pumpage on the Columbia Plateau was minimal during the early part of this century, increased moderately after World War II, and increased rapidly from about 1965 to 1979 in response to expanding use of ground water for irrigation. Since 1979, the pumpage has decreased somewhat, owing in part to higher electrical costs for pumping the water and lower prices for crops. The total irrigated acreage on the Columbia Plateau from 1949 to 1982 (U.S. Department of Commerce, 1982), shown in figure 35 , generally reflects this pattern. Differences are due to changes in irrigation and pump technology. Pumpage of ground water from the Columbia Plateau has increased from an estimated 55,690 acre-ft in 1945 , to 177,970 acre-ft in 1960 , to a peak of about 939,770 acre-ft in 1979 (D.R. Cline and C.A. Collins, U.S. Geological Survey, written commun., 1988). By 1983, pumpage had dropped to about 813,300 acre-ft.

Estimates of ground-water pumpage for 1984 have been made during this study for the Oregon part of the Columbia Plateau (Collins, 1987) and for the Washington part and a small part of Idaho (Cline and Knadle, 1990). It was concluded from the study that a total of 828,270 acre-ft of ground water were pumped from the regional aquifer system in 1984 from an estimated 3,500 high-capacity wells. Between 85 and 90 percent of the pumpage was used for irrigation of nearly 0.5 million acres; the rest of the pumpage was used for public water supply and industrial uses. The relatively small

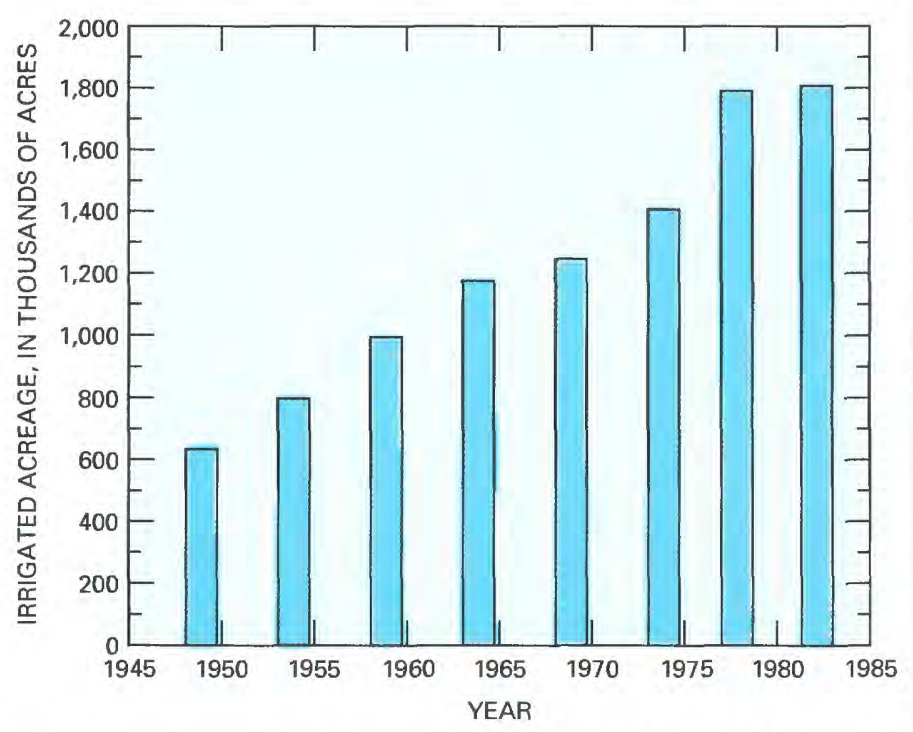

Figure 35.-Total irrigated acreage on the Columbia Plateau, 1949-82 (after U.S. Department of Commerce, 1982). quantity of ground water used for domestic purposes and other uses, such as stock watering, was not included.

Estimates of pumpage made during this study were based on one of the following three methods: (1) for wells equipped with flowmeters, pumpage data were directly available; (2) for wells with power-consumption data but no flowmeter, estimates of pumpage were made from a pumpagepower consumption relation derived from wells with flowmeter and power consumption data; and (3) for wells lacking flowmeter and power-consumption data, estimates were based on irrigated acreage, crop type, and water-application rates. In the State of Washington, information from published reports, field visits, population figures, remotesensing and Landsat scenes, water rights, an inventory of water suppliers, and well data were used to estimate pumpage where more specific data were lacking. More detailed information on the methods of determining ground-water pumpage for 1984 is given by Collins (1987) and Cline and Knadle (1990).

Estimates of the areal distribution of 1984 pumpage (see figs. 36-39) in each of the four studied hydrogeologic units were aggregated by quartertownship block. For wells that tap more than one unit, pumpage was divided proportionally according to the saturated thickness of each unit open to the well. Of the total 1984 ground-water pumpage from the regional aquifer system (fig. 40), about 32 percent was from the Grande Ronde unit, 39 percent from the Wanapum unit, 3 percent from the Saddle Mountains unit, and 26 percent from the overburden aquifer. The greatest concentrations of pumpage occur near Hermiston, Oreg., and in three centers in Washington-the Odessa subarea, the Quincy basin, and southern Franklin County.

\section{REGIONAL FLOW SYSTEM}

The occurrence, movement, and availability of ground water in the Columbia Plateau aquifer system are controlled by the geometry of the aquifer system, the hydraulic characteristics of the rock materials that make up the aquifer system, the distribution and rates of recharge and discharge, the development of the ground-water resource, and the application of irrigation water to croplands.

Water-level contours in the overburden aquifer for Washington and Oregon are shown in figure 41. The Washington data were collected and contoured for spring 1983 (Bauer and others, 1985). Oregon water-level data were collected by the 


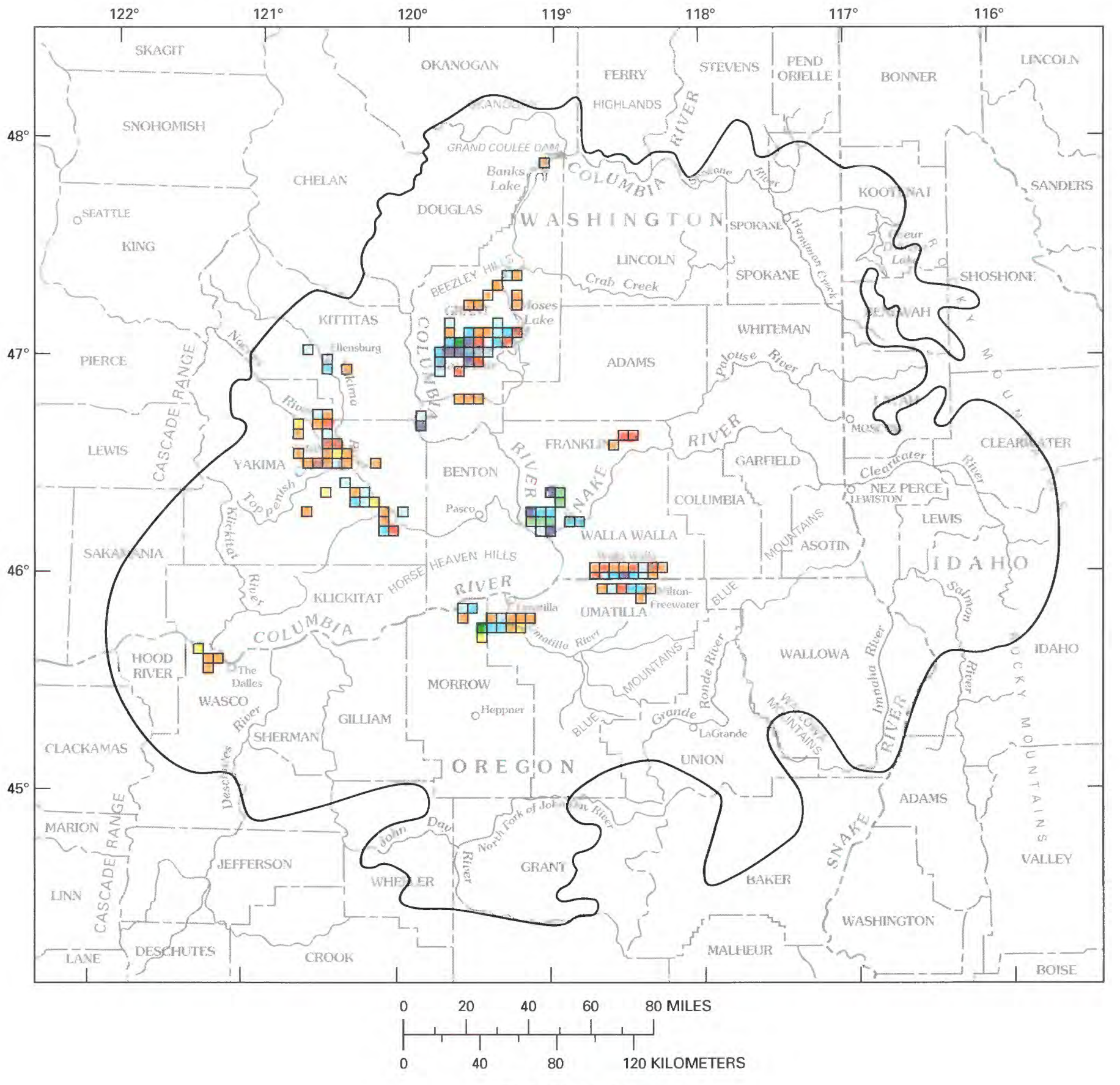

EXPLANATION

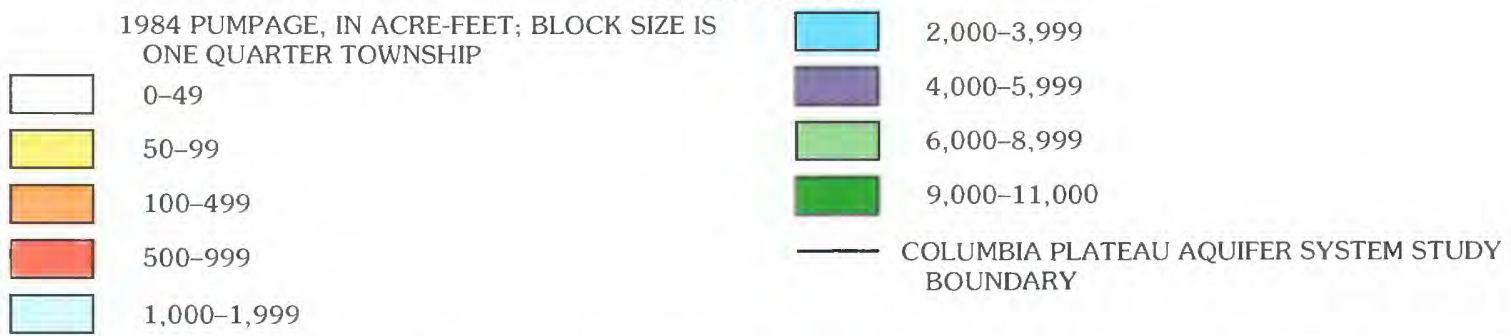

Figure 36.-Ground-water pumpage from the overburden aquifer, 1984. (Modified from Collins, 1987, and from Cline and Knadle, 1990.) 


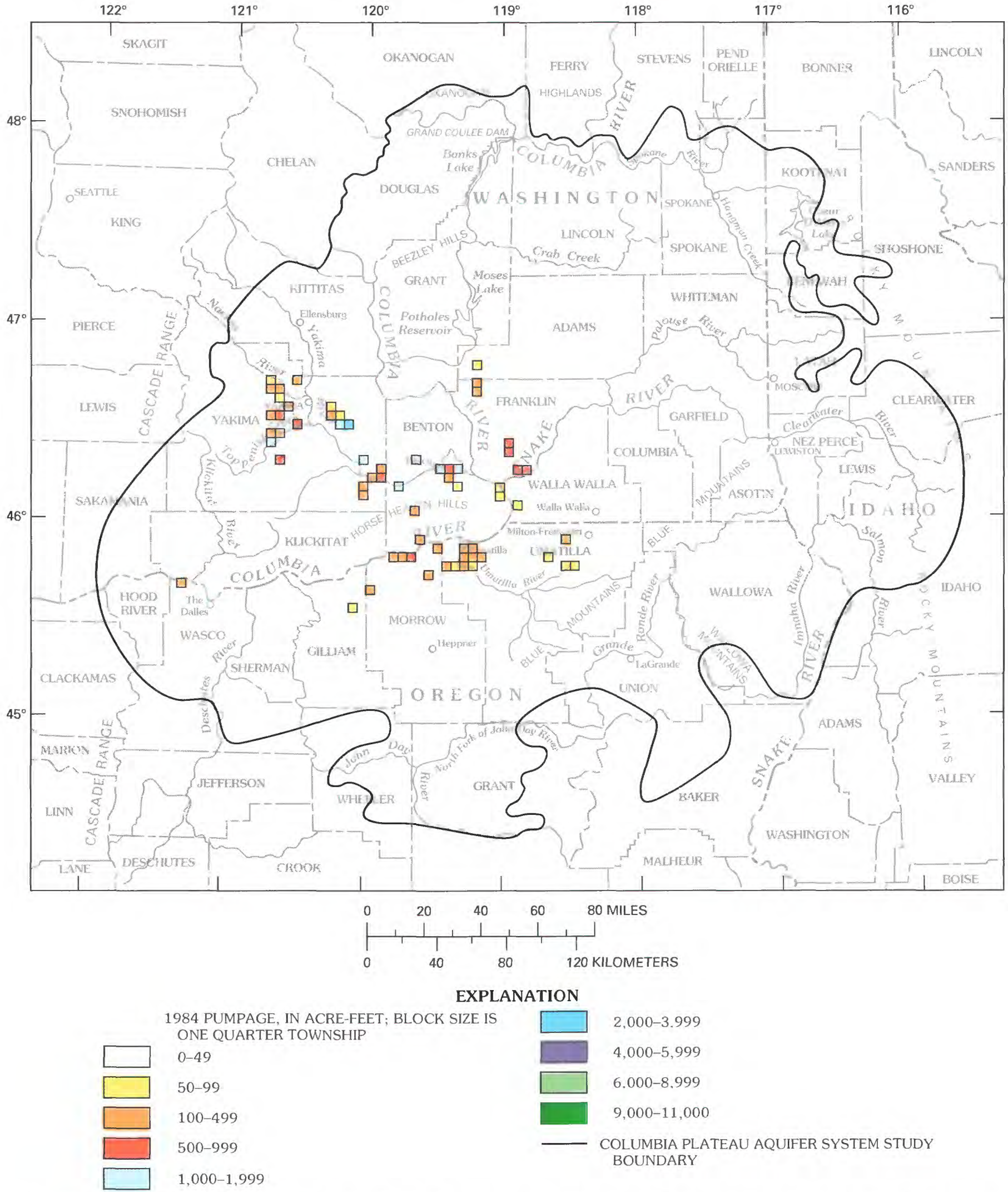

Figure 37.-Ground-water pumpage from the Saddle Mountains unit, 1984. (Modified from Collins, 1987, and from Cline and Knadle, 1990.) 


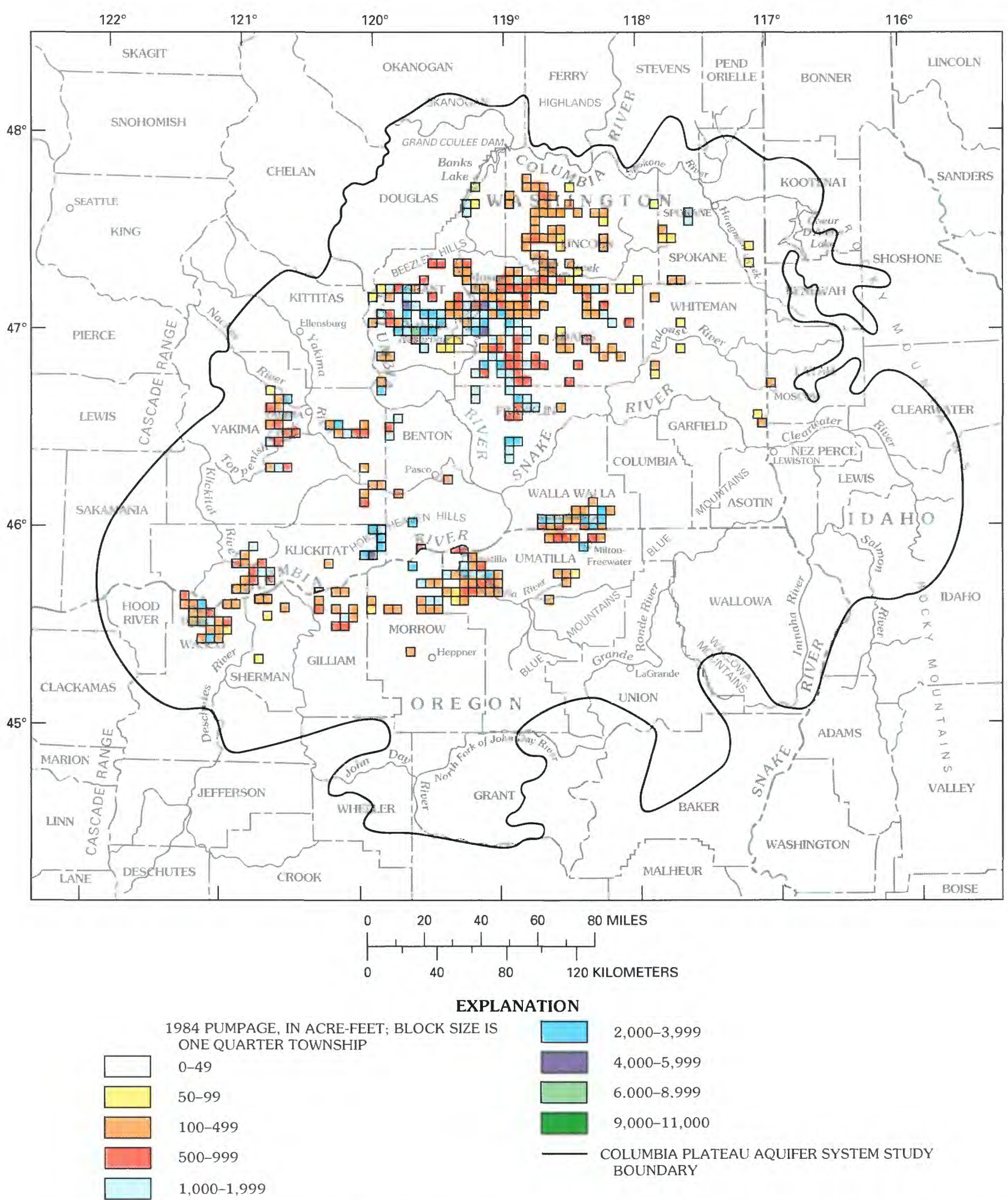

Figure 38.-Ground-water pumpage from the Wanapum unit, 1984. (Modified from Collins, 1987, and from Cline and Knadle, 1990.) 


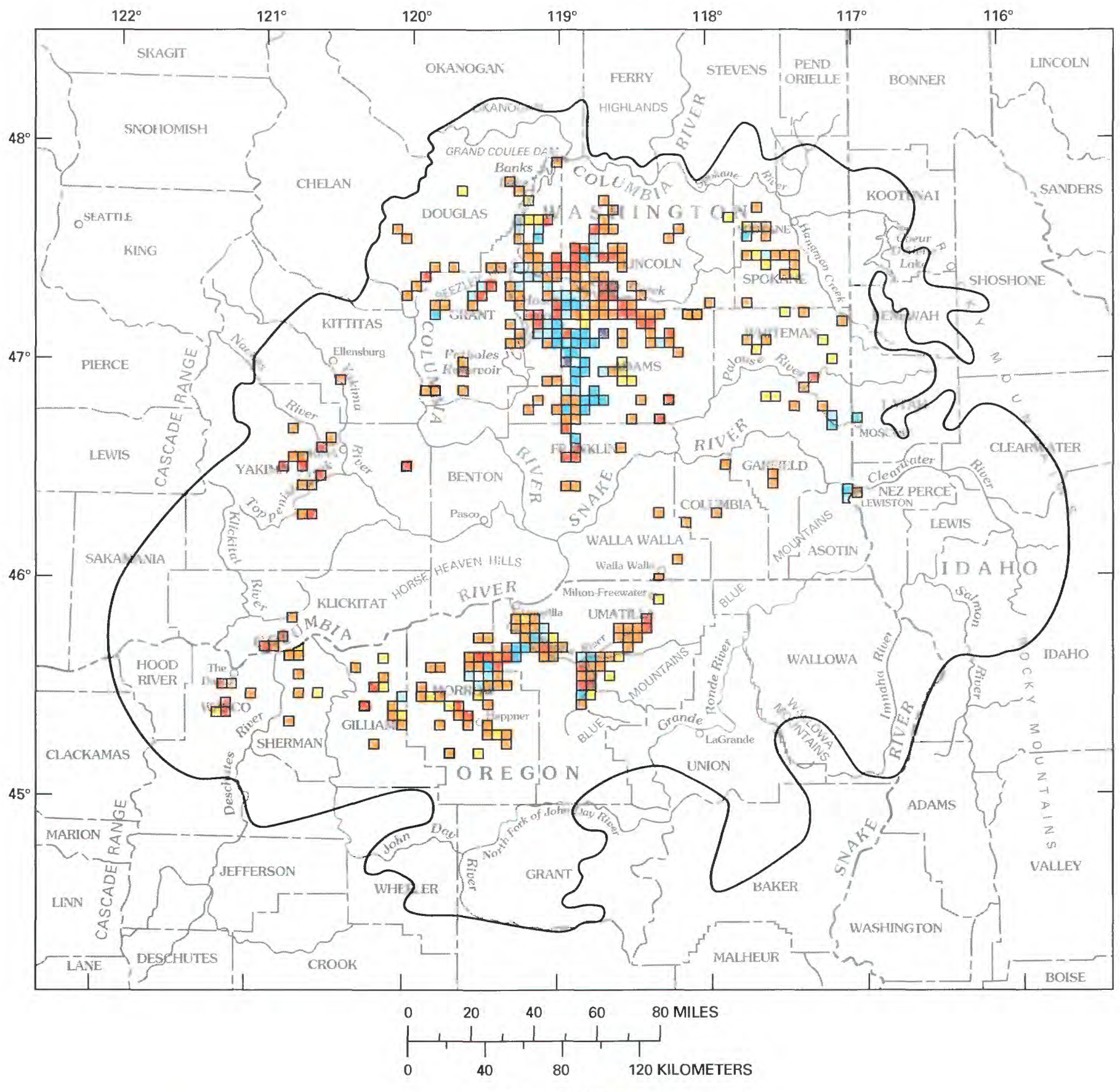

EXPLANATION

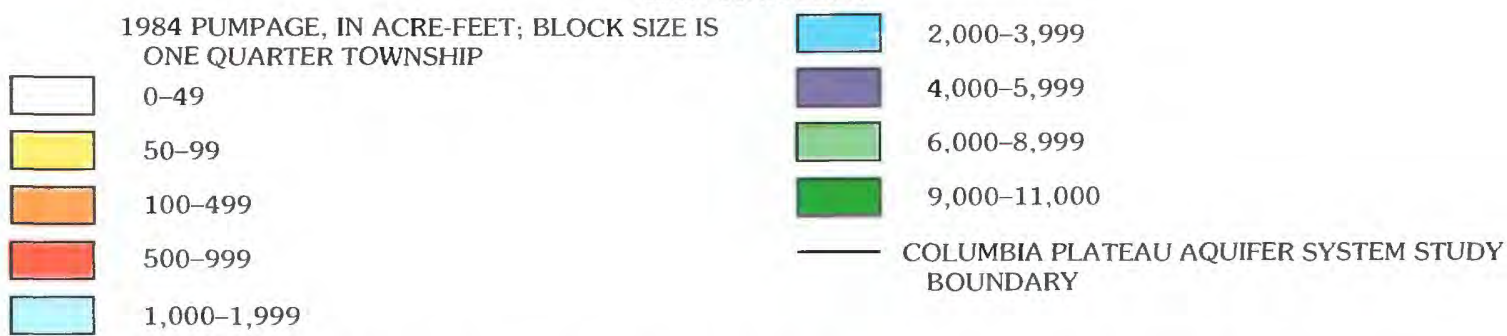

Figure 39.-Ground-water pumpage from the Grande Ronde unit, 1984. (Modified from Collins, 1987, and from Cline and Knadle, 1990.) 


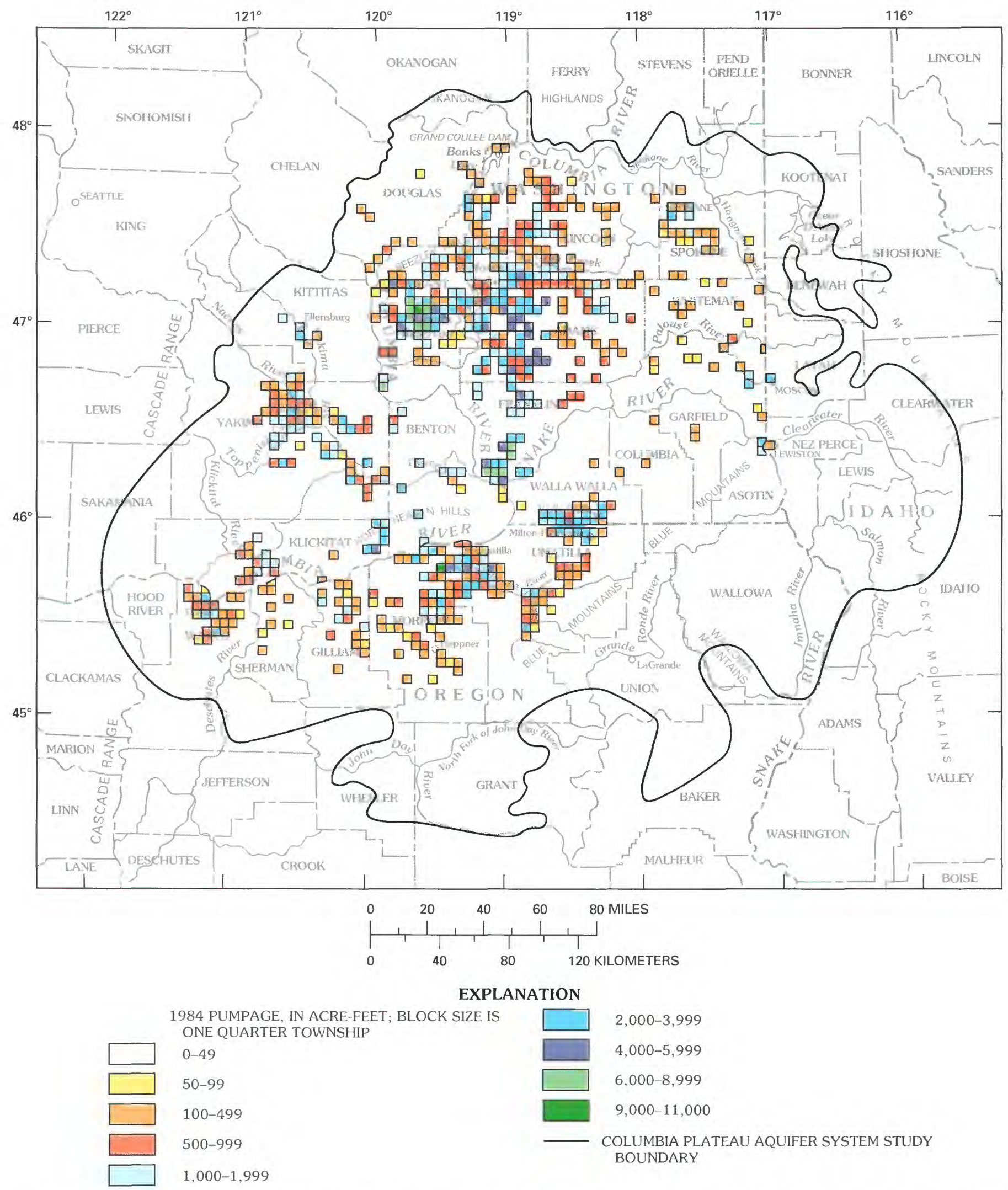

Figure 40,-Total ground-water pumpage from the Columbia Plateau aquifer system, 1984. (Modified from Collins, 1987, and from Cline and Knadle, 1990.) 


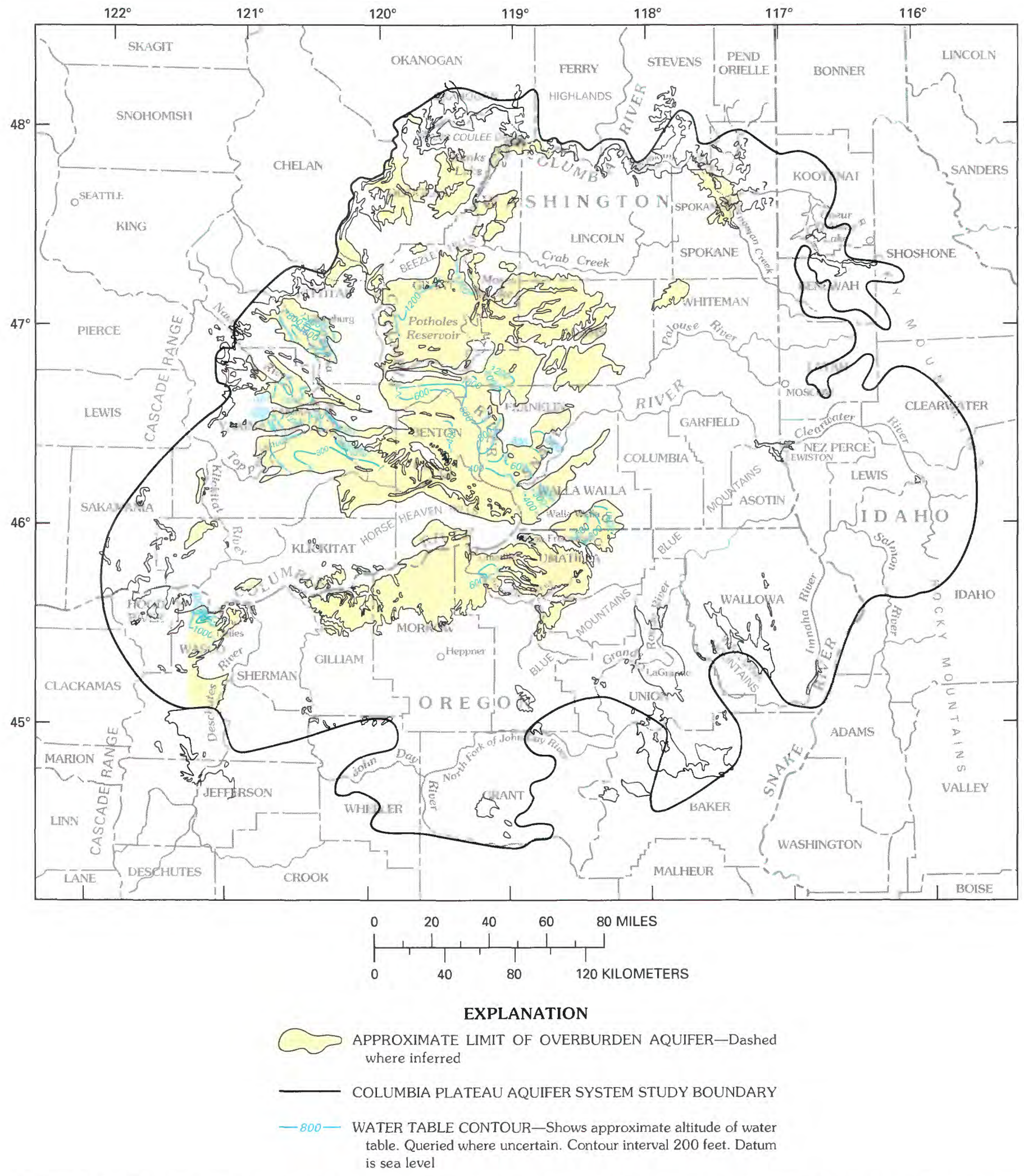

Figure 41.-Water table in the overburden aquifer representing conditions during the spring of 1983. (Modified from Bauer and others, 1985.) 
U.S. Geological Survey Oregon District and interpreted by Joseph B. Gonthier (U.S. Geological Survey, written commun., 1986). Data in the Umatilla area were collected in spring 1983 , but contours in The Dalles area are based on water-level measurements made in 1979. Because there is no evidence that a regional change in water levels in the overburden aquifer has occurred since that time, the 1979 data are assumed to be representative of the 1983 conditions. Where sediments are sufficiently thick, such as in the Quincy, Pasco, Yakima River, Walla Walla River, and Umatilla River basins, the overburden materials compose a water-table aquifer; otherwise, the materials are thin and (or) unsaturated and may not be an aquifer. The direction of ground-water flow is toward discharge points along major rivers that exist in these basins. Water in the overburden aquifer is in direct hydraulic connection with water in the immediately underlying basalt unit. Within the CBIP, much of the overburden was unsaturated prior to the importation of Columbia River water for irrigation. The overburden is now saturated in the CBIP areas, and the ground-water levels reflect the application of surface water for irrigation. Over most of the CBIP, the water-level configuration shown in figure 41 represents a dynamic equilibrium, with only small, localized declines caused by withdrawal of ground water, and small rises resulting from increased recharge due to infiltrating surface water used for irrigation.

Water-level contours for spring 1985 in the three basalt units are shown in figures 42-44. In general, changes of hydraulic head occur with depth at any given location, both within and between basalt units. The water-level contours drawn for a unit represent the vertically averaged areal hydraulic heads for that unit insofar as the data permitted. The contours are greatly generalized and present a simplified trend of hydraulic heads in a complex three-dimensional flow system. More detailed maps and a description of how these maps are constructed are discussed by Whiteman (1986) and Lane and Whiteman (1989).

The ground-water or potentiometric surface in the Saddle Mountains unit (fig. 42) approximately parallels the land surface where there is little or no overburden. Lateral flow in this basalt unit is generally toward major surface-drainage features, but small and intermediate-sized streams also derive flow from the Saddle Mountains unit. This type of ground-water flow also occurs in the Wanapum and Grande Ronde units (figs. 43, 44) where they are not overlain by younger basalts or by a great thickness of overburden. In the Palouse subprovince, north of the Snake River, the regional ground-water flow in both the Wanapum and Grande Ronde units approximately parallels the southwest regional dip slope of the basalt. Regional discharge is to the Columbia and Snake Rivers. In the Yakima Fold Belt subprovince, ground-water flow generally is downward from the anticline axes toward the streams and rivers lying in the intervening synclines. The tighter and narrower the synclines, the more the ground water tends to be confined because the synclines resemble structurally closed basins. Ground-water flow in the Blue Mountains subprovince is similar to that in the Yakima Fold Belt, approximately paralleling the land surface in areas of high relief and moving downward from the anticline axes to streams and rivers. Ground-water flow in the low-relief areas parallels the dip slope of the basalt but varies locally owing to geologic structure or is altered by groundwater development.

Water levels in the deeply buried parts of the Wanapum and Grande Ronde units are significantly different from those in the overlying units. In the south-central part of the plateau, water levels appear to be less influenced by surface-drainage features, and consequently the potentiometric surface is smoother. This is due, at least in part, to the fact that most recharge to and discharge from the deeply buried basalt is through vertical leakage over broad areas to and from the overlying basalt or overburden materials, rather than by direct hydraulic connection with surface-water bodies or drainage features. An example of this is in the Quincy basin, where ground-water flow in the Wanapum unit (which is at or near the land surface) is toward Moses Lake and Potholes Reservoir (located just south of Moses Lake). Ground-water flow in the underlying Grande Ronde unit, however, is unaffected by these surface-water bodies and is to the south, toward the Columbia River. Where the regional aquifer system consists mainly, if not completely, of the Grande Ronde unit and is more than $500 \mathrm{ft}$ thick, the configuration of the potentiometric surface in the lower part of the Grande Ronde unit tends to be smoother, and the hydraulic gradient is flatter, similar to the buried units. This has been noted in Douglas County, Wash., and in the high-relief areas of the Blue Mountains. Lack of data precludes subdivision of the Grande Ronde unit in these locations, and, in general, most of the depth-averaged water levels, which are from shallower wells, do parallel the land surface. 


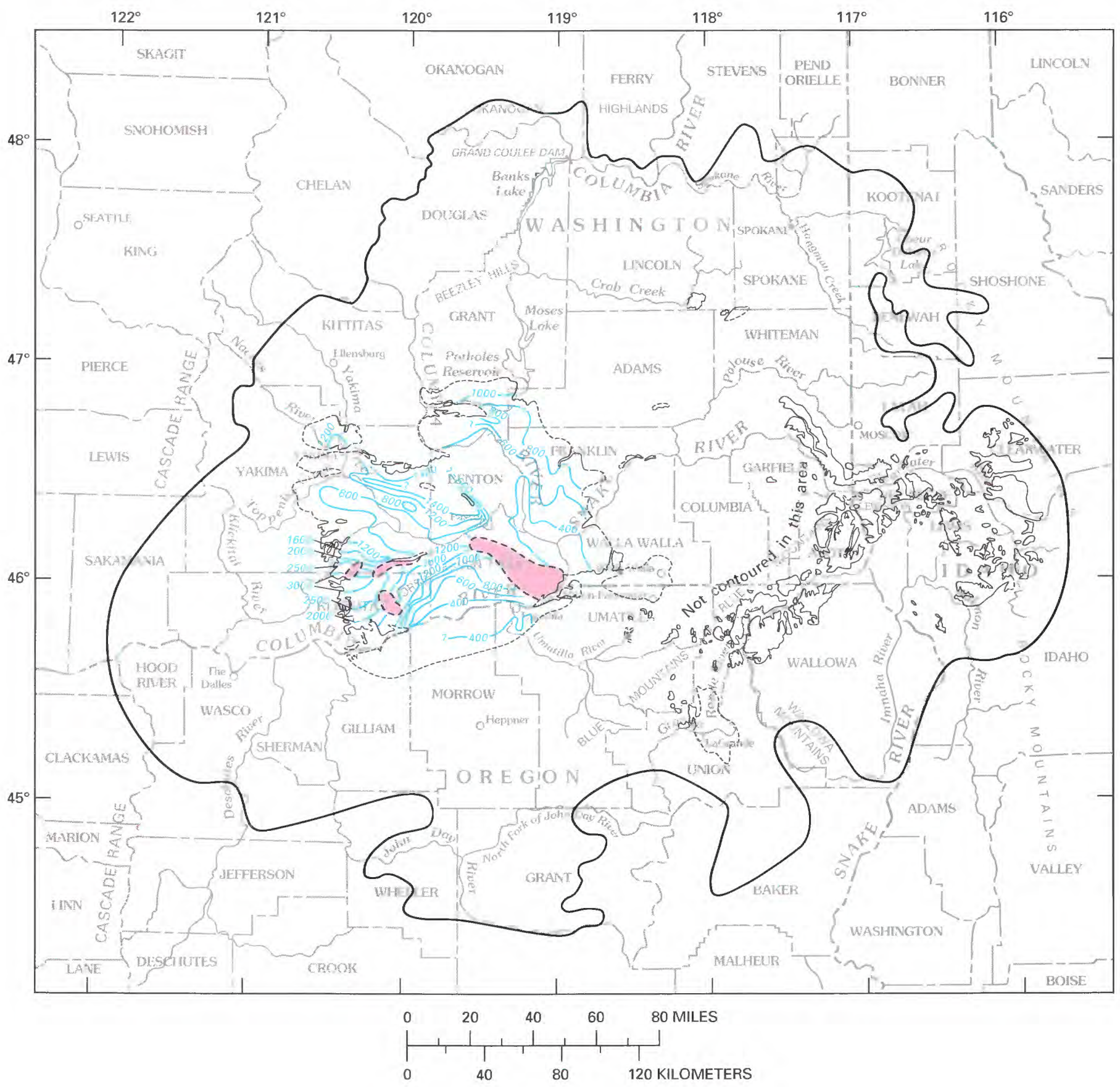

EXPLANATION

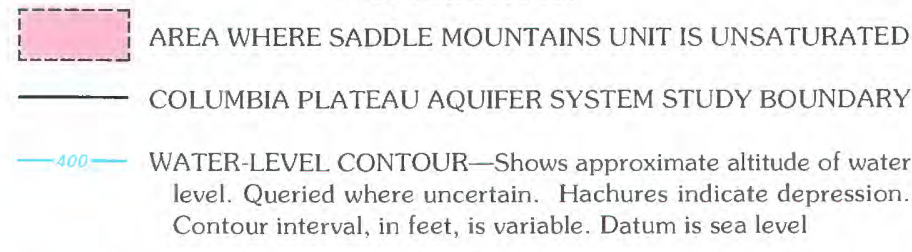

APPROXIMATE LIMIT OF SADDLE MOUNTAINS BASALT-Dashed where inferred

FIGURE 42.-Water-level contours for the Saddle Mountains unit, spring 1985. (Modified from Whiteman, 1986, and from Lane and Whiteman, 1989.) 


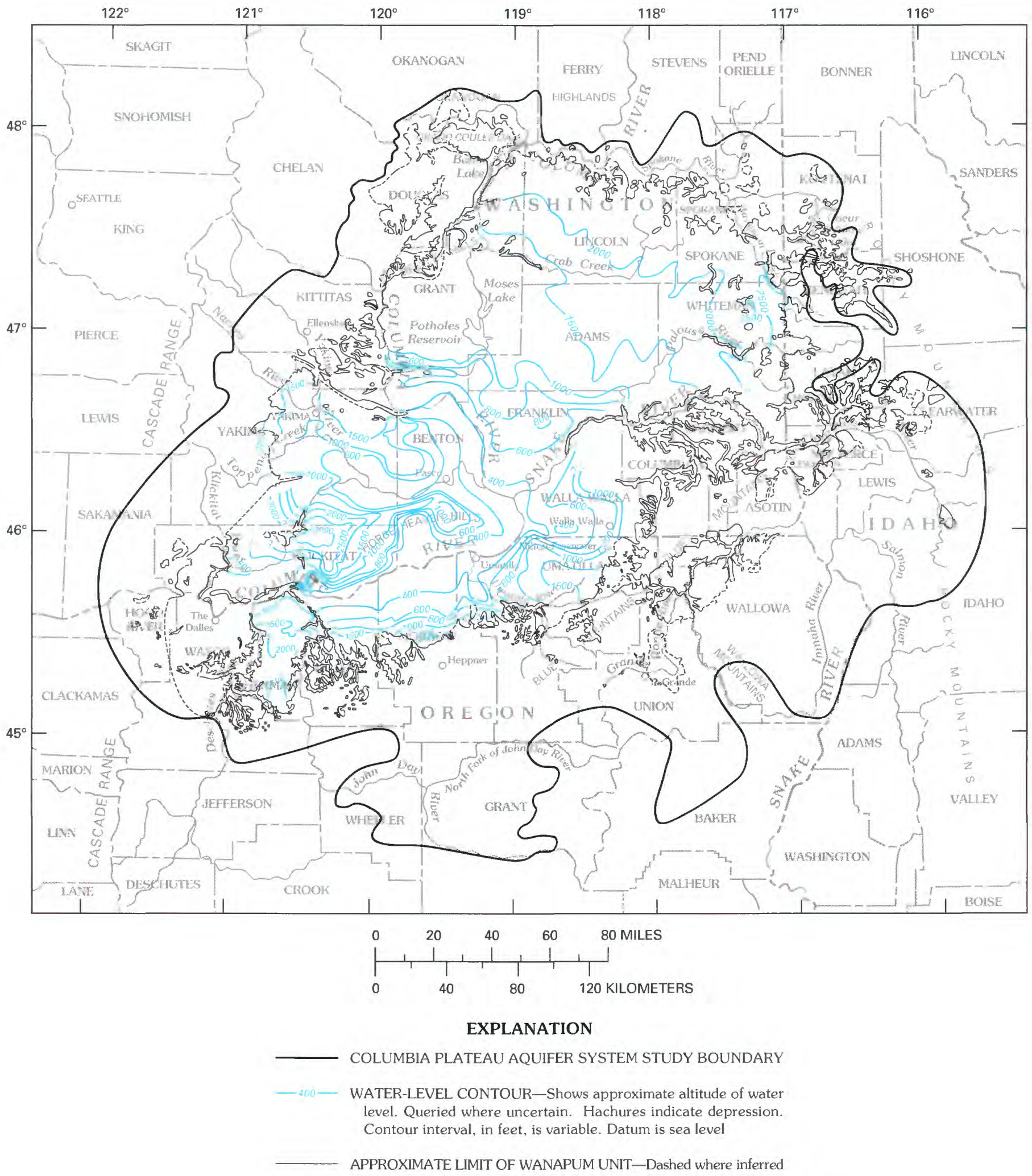

Figure 43.-Water-level contours for the Wanapum unit, spring 1985. (Modified from Whiteman, 1986, and from Lane and Whiteman, 1989.) 


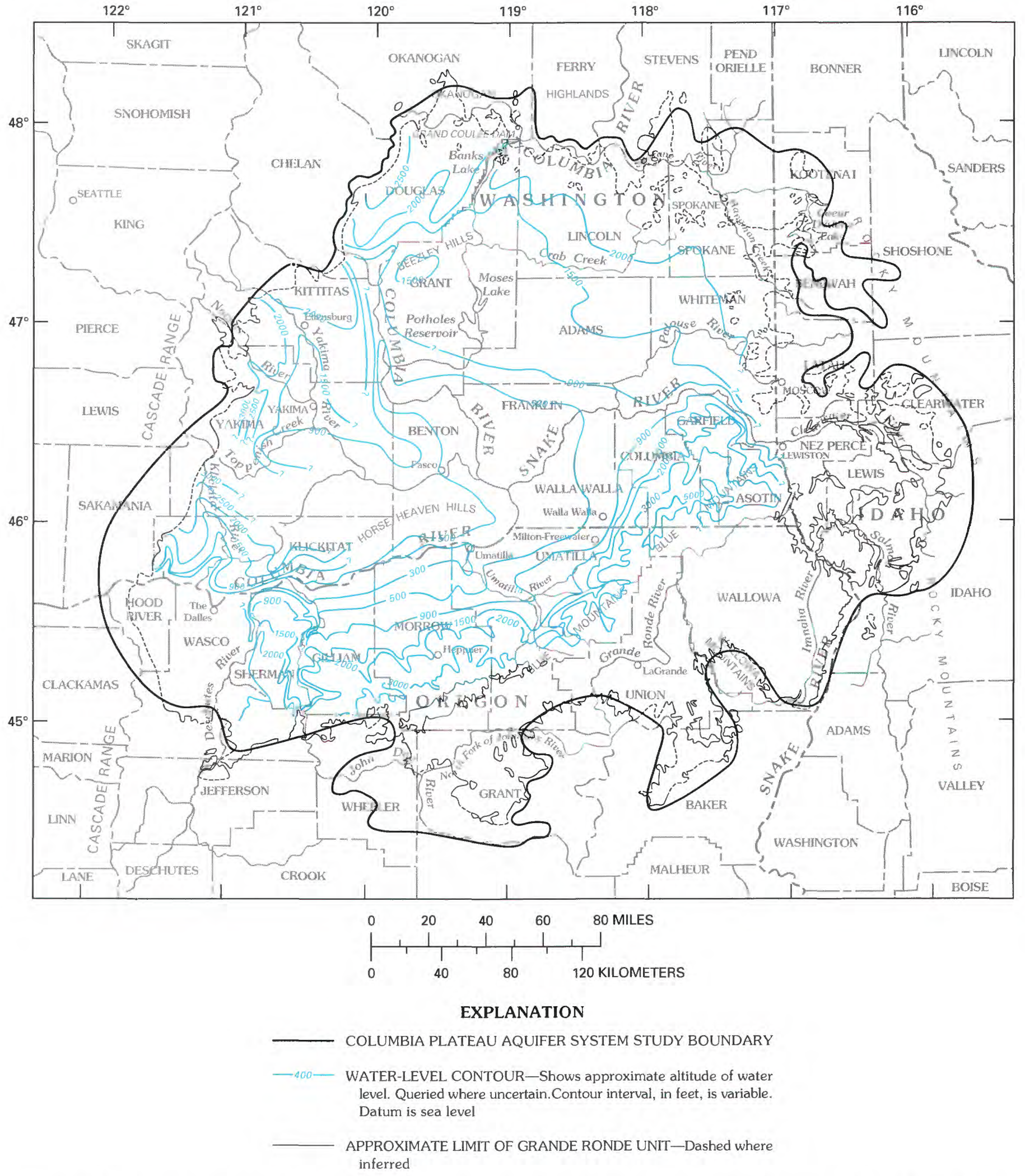

Figure 44,-Water-level contours for the Grande Ronde unit, spring 1985. (Modified from Whiteman, 1986, and from Lane and Whiteman, 1989.) 
In most of the study area, water-table or unconfined conditions exist in the uppermost basalt flows, whereas water in the deeper basalt is generally confined. Fine-grained, tight interbeds, where present, and some basalt flow centers are confining beds to the underlying flows. The hydraulic connection between flows is sufficient to allow vertical movement of water between them. From the available water-level data it appears that over most of the plateau the vertical flow is downward except near discharge areas. The exceptions to this trend occur near geologic structures, such as anticlines and faults, and areas with high pumpages. According to Newcomb (1961), faulting in the basalt near Walla Walla and in the Cold Creek syncline near Yakima in Washington and southwest of The Dalles in Oregon has caused lateral-flow impediments, resulting in upward flow. F.A. Packard (U.S. Geological Survey, written commun., 1987) reports that in the central part of the Horse Heaven Hills, water in wells tapping the Wanapum unit is confined and flows at the surface, but approximately 2 mi downgradient to the southeast the water levels in wells tapping the Wanapum unit are about $340 \mathrm{ft}$ lower. This variation in water levels and change in direction of flow are caused by some impediment that is inferred to be a fault system. The vertical hydraulic gradient is upward northwest of this impediment and downward southeast of it.

Steep gradients are shown on the flanks of the Blue Mountains, Horse Heaven Hills, Frenchman Hills, Rattlesnake Hills, and Saddle Mountains anticlines (figs. 42, 43). Water-level data from locations on the flanks of anticlines and in other areas where the basalt is steeply dipping show lateral water-level gradients to be approximately equal to or slightly less than the dip slope of the basalts.

Since the mid-1960's, pumping for irrigation has altered the regional flow. For example, in the area of Connell and northward toward the Odessa-Lind area (fig. 43), an upgradient bending of the contours, typical of lowered water levels, can be seen. A similar trend of upgradient contours attributed to pumping is in the Umatilla River basin in Oregon.

The effects of induced recharge from irrigation canals on the potentiometric surface are shown by the downgradient trend of contour just east of Othello (fig. 43), between the 1,000- and 800-ft contours, where the large East Low Canal is located and is part of the CBIP.

Seasonal water-level fluctuations in the aquifer system vary widely, probably because of the following major factors: (1) variations in precipitation, (2) storage capacity of rock materials, and (3) irrigation practices. Seasonal water-level changes in the overburden materials in the Satus Creek and Toppenish areas in Washington generally are less than $10 \mathrm{ft}$ but may be as much as $20 \mathrm{ft}$ in alluvial sediments (U.S. Geological Survey, 1975; Mundorff and others, 1977; Prych, 1983). Newcomb (1965) and Barker and MacNish (1976) have reported more than $30 \mathrm{ft}$ of seasonal water-level changes in the overburden aquifer in the Walla Walla River basin. Hydrographs of U.S. Geological Survey observation piezometers located in Washington (fig. 45) typically show seasonal water-level fluctuations of less than $10 \mathrm{ft}$ in the shallower basalt units. However, water levels in deeply buried basalt flows fluctuate more than those of the shallower units (fig. 45). These larger fluctuations are due to the effects of pumpage. Several of the hydrographs in figure 45 show long-term water-level declines; these changes are discussed in more detail in the next section.

\section{EFFECTS OF DEVELOPMENT}

Water-level changes from predevelopment to the present (1985) are difficult to assess because of the complexity of the aquifer system, the lack of wellconstruction data, and the number of wells open to several aquifers. Nevertheless, a generalized map of water-level changes for the Wanapum unit was constructed (fig. 46). Similar patterns of change in water levels probably occur in other hydrogeologic study units as well, although the degree of change probably is less in the Grande Ronde unit.

The East Low Canal marks the general boundary in the central plateau between water-level rises in the Wanapum unit to the west and water-level declines to the east. Water-level rises began with the completion of the canal in the early 1950's, and in most areas the water levels had stabilized to a new equilibrium by the mid-1970's. The hydrographs of wells 14N/29E-27E01 and 19N/23E-34R01 (fig. 47) indicate the rise of the water levels. The largest rises occurred in the Quincy basin, where water levels rose more than $300 \mathrm{ft}$, and in the area east of Potholes Reservoir, where water levels rose more than $150 \mathrm{ft}$.

Water-level declines resulting from pumping for irrigation began in the 1960's and are concurrent with the increase in irrigated acreage. The initial decline in water levels occurred in five areas: (1) western Adams and southern Lincoln Counties, Wash.; (2) Walla Walla River basin, Wash.; (3) the Pullman, Wash.-Moscow, Idaho, area; (4) The 

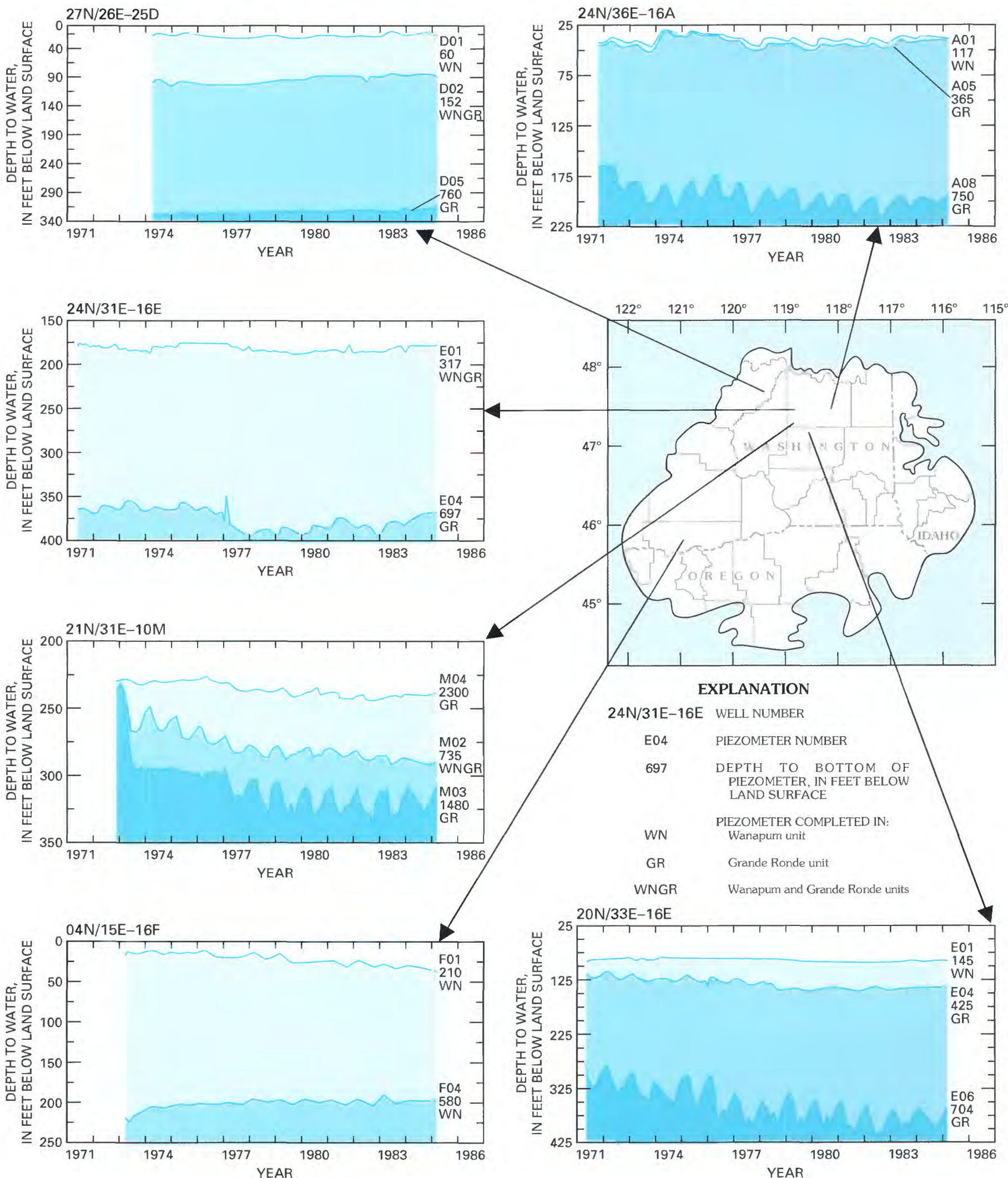

Figure 45.-Seasonal water-level fluctuations for selected piezometers. 
Dalles, Oreg.; and (5) the Hermiston, Oreg., area. 15N/45E-32N03 and 17N/32E-19E01 (fig. 47) indiWater-level declines in the Horse Heaven Hills cate these water-level declines. In general, water began in the early 1970's. The hydrographs of wells levels in the above five areas continue to decline,

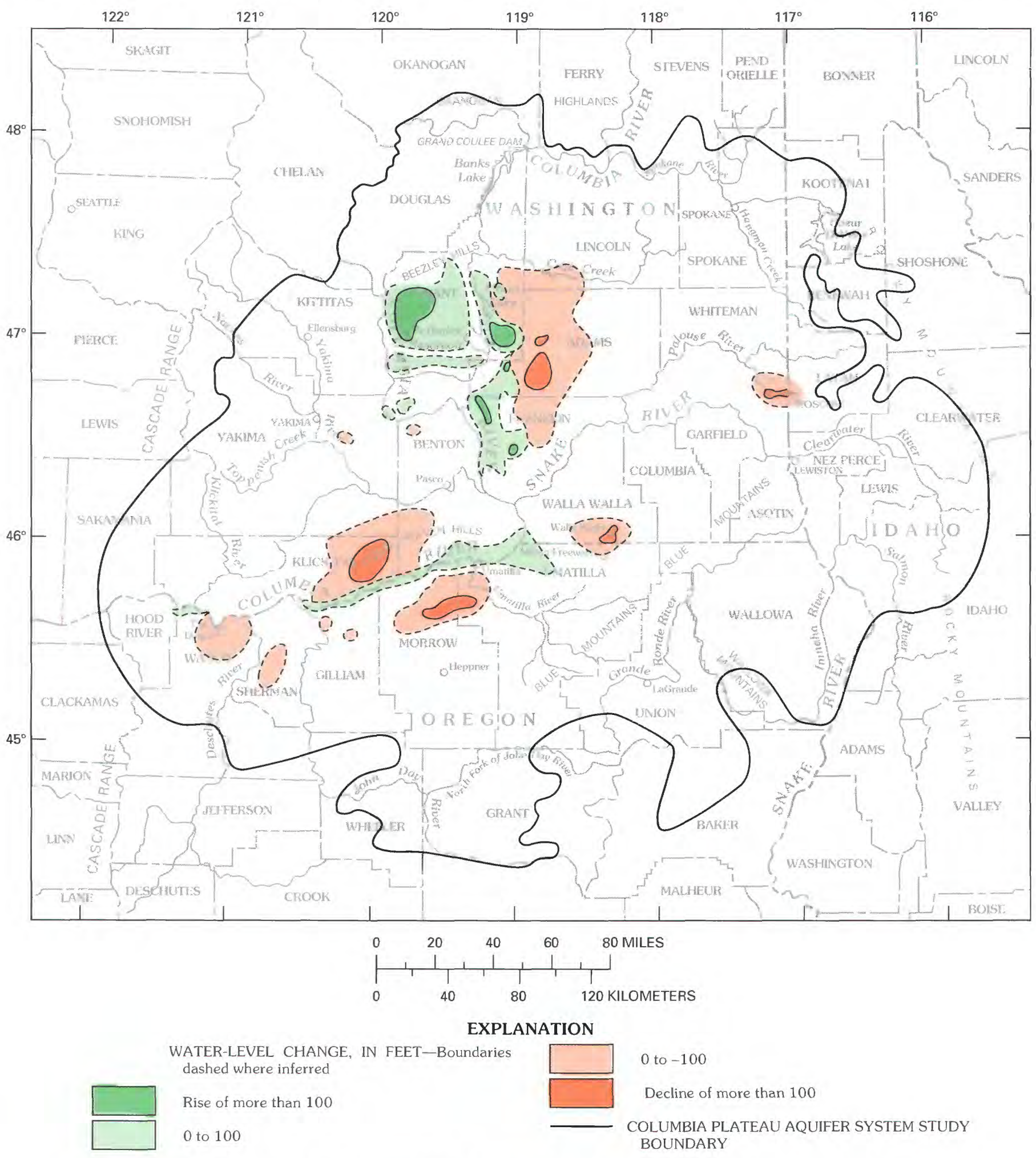

Figure 46.-Water-level changes in the Wanapum unit from predevelopment (1850's) to 1985. 

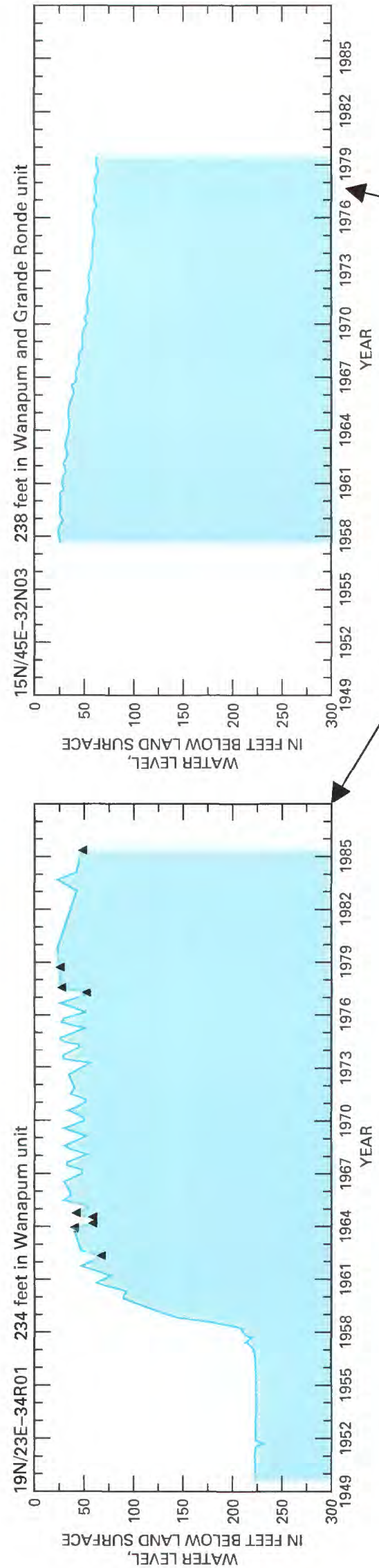
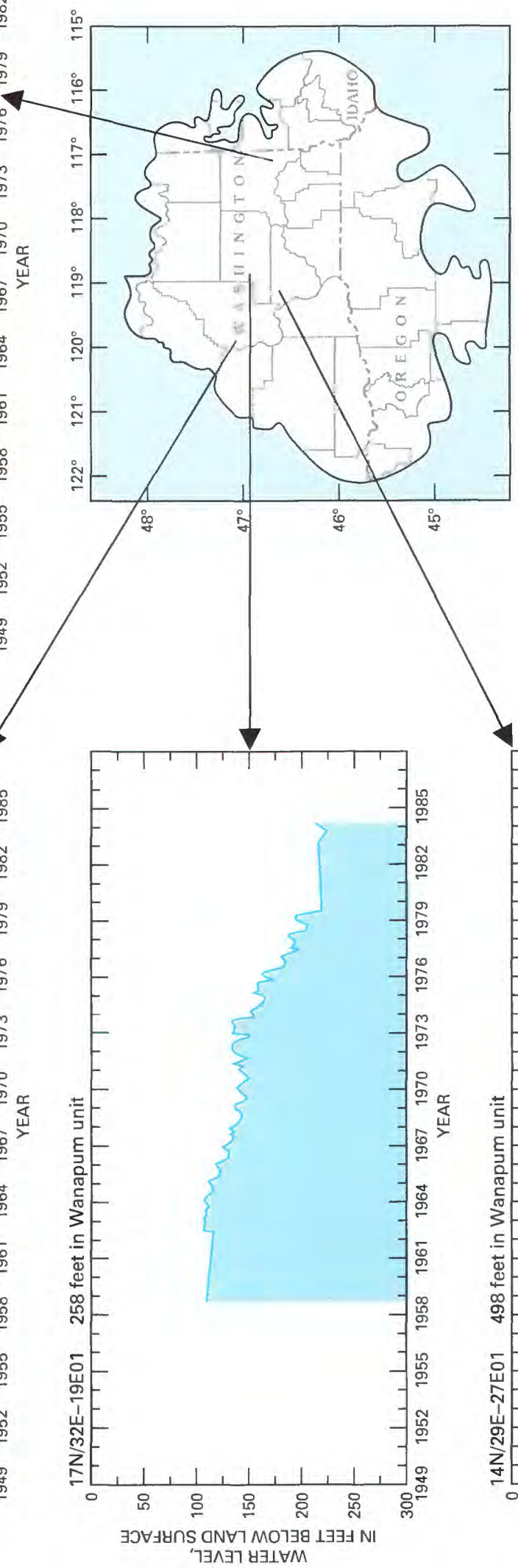

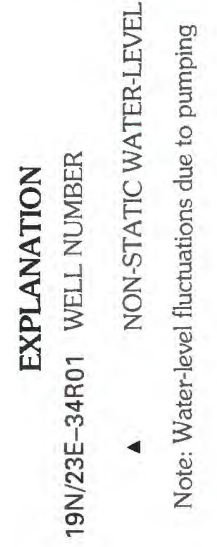


and the size of the affected areas has increased with time (Luzier and others, 1968; Cline, 1984). The rate of water-level decline, however, has decreased, at least in the central part of the plateau, as evidenced by the hydrographs for wells 24N/36E-16A08 and 21N/31E-10M02 (fig. 45). The largest water-level declines in the Wanapum unit had exceeded $150 \mathrm{ft}$-in the Walla Walla River basin, the Horse Heaven Hills, the Hermiston area, and the central plateau.

Water-level rises and declines affect regional flow. Prior to development, the dominant direction of ground-water flow across the northern half of the plateau is assumed to have been southwesterly, from the northern and eastern plateau margins toward the Columbia and Snake Rivers. However, the 1985 potentiometric surface of the Wanapum unit reflects the effects of the development (fig. 43). In places, the ground-water flow changed direction; for example, in an area between Scootenay Reservoir and Connell in northern Franklin County, ground water now flows southeasterly instead of southwesterly.

\section{GEOCHEMISTRY}

One of the principal factors in the development of the Columbia Plateau is the availability of large quantities of ground water for irrigation. The suitability of water is dependent on the quality of the water. An understanding of the processes that affect and control the ground-water quality is important. Ground-water chemistry also can significantly affect the hydrologic characteristics of the rock comprising the aquifer system. The filling of fractures with mineral precipitates from chemically reactive volcanic glass (which usually progresses farther in older volcanic rocks than in younger rock) results in decrease of hydraulic conductivity. This is believed to be related to the rate of groundwater flow, the availability of the chemically reactive volcanic glass, and the relatively porous nature of volcanic rocks that results in a large surface area per unit volume to come into contact with the water (Wood and Fernandez, 1988). The sections that follow discuss evolution of the groundwater chemistry in the basalt, describe major water-quality characteristics of the three basalt study units, and discuss the effects of surface- and ground-water development on water chemistry. The information is summarized from Hearn and others (1985), Steinkampf and others (1985), Wood and Fernandez (1988), and Steinkampf (1989).

\section{CHEMICAL EVOLUTION OF THE GROUND WATER}

The chemical composition of water in the Columbia Plateau aquifer system depends on the composition and relative solubility of the rocks through which the water flows, the chemical composition of the recharge water, and the residence time of the water in the aquifer system.

Rocks of the Columbia River Basalt Group consist primarily of labradorite (plagioclase feldspar), augite (pyroxene), and opaque metal oxides (commonly titanomagnetite) in a glassy to cryptocrystalline matris. The most common accessory minerals are apatite, olivine, and metallic sulfides. These minerals are present in varying and relatively minor amounts as intergrown and isolated crystals. The most abundant secondary minerals are a nontronitic smectite, quartz, clinoptilolite, and iron oxyhydroxides (Ames, 1980; Benson and Teague, 1982; Hearn and others, 1985). The Grande Ronde, Wanapum, and Saddle Mountains Basalts are compositionally distinct, and individual flows within these units also can have distinct mineral compositions. On the basis of bulk compositions, Swanson and Wright (1978) described eight chemical types of basalt in the northern part of the plateau.

The primary means by which solutes are added to ground water in the basalt are (1) dissolution of rock by weakly acidic recharge waters and (2) silicate hydrolysis. The presence of a soil zone in the recharge area increases the dissolution capacity of the recharging water by carbon dioxide generation. Carbon dioxide is formed by the microbial oxidation of organic carbon and dissolves to carbonic acid. In areas devoid of a soil zone or vegetative cover, and in confined aquifers where little or no oxygen penetrates from the atmosphere, carbonic acid generally is not generated. In such areas, silicate hydrolysis is the dominant dissolution process. Volcanic glass, a major component of the Columbia River Basalt Group, is the most reactive mineral. It is relatively unstable and reacts rapidly because of the presence of large internal surface areas resulting from cooling fractures and devitrification (Jones, 1966). In decreasing order, cryptocrystalline intergrowths, olivine, pyroxene, and feldspar are the next most reactive minerals.

The most abundant solutes added to ground water by dissolution of the basalt are calcium, magnesium, iron, sodium, potassium, silica, sulfate, chloride, fluoride, and bicarbonate. The relative concentrations of each in ground water are determined by their availability in the rock, by water-rock reactions, and by reactions occurring 
after dissolution. Dissolution of minerals by carbonic acid increases both the concentrations of all of the above solutes and the $\mathrm{pH}$ values in ground water. Silicate hydrolysis also increases the concentrations of all solutes and, because the hydroxyl ion is produced in the reaction, increases $\mathrm{pH}$ more than does acidic dissolution. As ground-water $\mathrm{pH}$ rises, it eventually exceeds the stability limits of calcium carbonate, which can then precipitate calcite from solution, lowering calcium and magnesium levels and contributing to decreased iron concentrations, effectively buffering the groundwater $\mathrm{pH}$. Sodium and potassium are primarily derived from volcanic glass and cryptocrystalline intergrowths and somewhat from plagioclase feldspar, and they are dissolved at a rate faster than that at which they are precipitated. As dissolved sodium, potassium, and silica concentrations increase, the ground water eventually becomes supersaturated with respect to clinoptilolite. The latter mineral, which incorporates dissolved sodium and potassium, then precipitates, therefore limiting the concentrations of sodium and potassium in water in the basalts.

Dissolved silica concentrations are large, on the order of $50 \mathrm{mg} / \mathrm{L}$, in basaltic ground water because of the readily dissolved glassy material present. Silica levels are limited by the solubility of amorphous or opaline silica. The relatively large silica concentrations buffer the $\mathrm{pH}$ of the water, limiting the increase from the hydrolysis reaction to a $\mathrm{pH}$ of about 9.5 .

Sulfate in ground water in the basalt has three likely sources. The first is the dissolution of accessory metallic sulfide minerals, such as pyrite, in the presence of dissolved oxygen. The second is the dissolution of anhydrite or gypsum from sedimentary interbeds interlayered with the basalt. Sulfate minerals in the interbeds are likely to be of either eolian or evaporative (caliche) origin. The third source is agricultural chemicals present in groundwater recharge. Sulfide has been found in some ground-water samples from the plateau and is probably derived from the microbial reduction of dissolved sulfate.

Trace elements in the ground water also are derived from the weathering of minerals composing the rock matrix, and their concentrations in ground water are dependent on a variety of factors, many of which are difficult to quantify. Concentrations of some trace elements are controlled by the chemical characteristics of the ground water, whereas concentrations of others are a function of their availability in the basaltic rock. For example, the concentrations of barium, calcium, fluorine, and iron are likely controlled by the chemical characteristics of the water and the solubilities of relevant secondary minerals such as barite, calcite, fluorite, and iron oxyhydroxides. In contrast, elements such as lithium, strontium, and boron (which increase in concentration with increasing total dissolved-solids concentration) are usually controlled by availability of the element in the rock.

\section{WATER-QUALITY CHARACTERISTICS}

The areal and vertical distribution of selected dissolved chemical constituents and physical properties of water from the Saddle Mountains, Wanapum, and Grande Ronde units have been mapped on the basis of analyzed water samples and discussed by Steinkampf (1989). A summary of water-chemistry statistics for the three basalt units, taken from Steinkampf (1989), is presented here as table 7 . Ground water in the basalt units is generally of good quality and suitable for most uses. The dominant water type in all three units is calcium magnesium bicarbonate $\left(\mathrm{CaMgHCO}_{3}\right)$, and sodium bicarbonate $\left(\mathrm{NaHCO}_{3}\right)$ is the next most prevalent water type. Sodium bicarbonate waters typically occur in deeper downgradient locations. Similarly, the concentrations of dissolved solids generally are higher in downgradient locations or in deeper parts of the aquifer system. This is because of a larger residence time of water in the system, resulting from an increase in length of flow paths. Therefore, the similar areal trend in $\mathrm{NaHCO}_{3}$ and concentrations of dissolved solids indicates that sodium concentrations in the ground water increase with ground-water residence time.

In the Saddle Mountains unit where surfacewater irrigation occurs and where the overburden is less than $200 \mathrm{ft}$ thick, water from shallow wells (less than $400 \mathrm{ft}$ ) is of a calcium magnesium sulfate chloride $\left(\mathrm{CaMgSO}_{4} \mathrm{Cl}\right)$ type (fig. 48). Dissolvedsolids concentrations generally increase in a downgradient direction owing to longer residence time of water in the aquifer system. In irrigated areas the concentration of dissolved solids may further be increased by contaminated infiltrating irrigation water. The infiltrating surface water transports large quantities of nitrogen derived from agricultural chemicals. Nitrogen concentrations (nitrate plus nitrite as $\mathrm{N}$ ) in ground water of $2.0 \mathrm{mg} / \mathrm{L}$ or larger occur in areas where the overburden aquifer is thin and where surface water is used for irrigation. 
TABLE 7.-Summary of selected water chemistry for the three basalt units (from Steinkampf, 1989)

[Values are in milligrams per liter unless otherwise indicated]

\begin{tabular}{|c|c|c|c|}
\hline & Maximum & Minimum & Mean \\
\hline \multicolumn{4}{|c|}{ A. Saddle Mountains unit, 181 water analyses } \\
\hline $\begin{array}{l}\text { Specific conductance (microsiemens } \\
\left.\text { per centimeter at } 25^{\circ} \mathrm{C}\right) \text {. }\end{array}$ & 1,460 & 175 & 498. \\
\hline Calculated dissolved solids ......... & 890 & 140 & 340.2 \\
\hline odium $(\mathrm{Na})$ & 100 & 7.3 & 34.5 \\
\hline hloride (Cl) _ & 130 & 1.3 & 24.3 \\
\hline Nitrate+nitrite $\left(\mathrm{NO}_{3}+\mathrm{NO}_{2}\right.$, as $\left.\mathrm{N}\right)$ - & 54 & .1 & 4. \\
\hline Silica $\left(\mathrm{SiO}_{2}\right)$ & 72 & $36^{.4}$ & 55. \\
\hline Sulfate $\left(\mathrm{SO}_{4}\right)$ & 490 & .2 & 53 \\
\hline 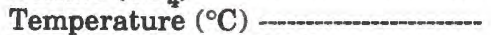 & 25.5 & 8.6 & 18. \\
\hline d oxygen (DO) & 10.1 & .1 & 4. \\
\hline Calcium $(\mathrm{Ca})$ & 98 & 1.9 & 38. \\
\hline Magnesium (Mg) & 62 & .28 & 19. \\
\hline ide $(F)$ & 2.9 & .2 & .5 \\
\hline Bicarbonate $\left(\mathrm{HCO}_{3}\right)$ & 392 & 108 & 195. \\
\hline Iron $(\mathrm{Fe})$ & .79 & .003 & .03 \\
\hline Potassium (K) & 13 & 1.5 & 6.9 \\
\hline $\mathrm{pH}$ (units) - & 8.7 & 7.0 & ${ }^{\mathrm{a}} 7.7$ \\
\hline
\end{tabular}

B. Wanapum unit, $\mathbf{4 1 0}$ water analyses

Specific conductance (microsiemens

$\begin{array}{ll}\left.\text { per centimeter at } 25^{\circ} \mathrm{C}\right) \text {. } & 1,970 \\ \text { Calculated dissolved solids } & -\ldots . . .-1,100\end{array}$

Sodium (Na) - 130

Chloride (Cl) - _._._._._._. 300

Nitrate+nitrite $\left(\mathrm{NO}_{3}+\mathrm{NO}_{2}\right.$, as $\left.\mathrm{N}\right)$ - $\quad 35$

Silica $\left(\mathrm{SiO}_{2}\right)-100$

Sulfate $\left(\mathrm{SO}_{4}\right)$ -

Temperature $\left({ }^{\circ} \mathrm{C}\right)$ -

Dissolved oxygen (DO) -.__ $\quad 10.6$

Calcium $(\mathrm{Ca})$ - 180

Magnesium $(\mathrm{Mg})$

Fluoride $(\mathrm{F})$

Bicarbonate $\left(\mathrm{HCO}_{3}\right)$

Iron $(\mathrm{Fe})$

Potassium $(\mathrm{K})$

$\mathrm{pH}$ (units)

$\begin{array}{cr}102 & 402.5 \\ 69 & 269.5 \\ 2.4 & 28 \\ 7 & 17.2 \\ .1 & 3.7 \\ 10 & 48.3 \\ .2 & 29.3 \\ 6.2 & 15.5 \\ .1 & 5.2 \\ .8 & 32.8 \\ .1 & 14.8 \\ .1 & .5 \\ 53 & 178.1 \\ .003 & .03 \\ .9 & 4.9 \\ 6.1 & 97.4\end{array}$

406

1.1

22
Maximum Minimum

Mean

C. Grande Ronde unit, 283 water analyses

Specific conductance (microsiemens

$\begin{array}{llll}\text { per centimeter at } 25^{\circ} \mathrm{C} \text { ). } & 830 & 85 & 311.8\end{array}$

Calculated dissolved solids

Sodium (Na) - $\quad 90 \quad 4 \quad 24.9$

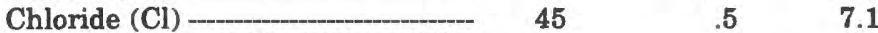

$\begin{array}{lrrr}\text { Nitrate+nitrite }\left(\mathrm{NO}_{3}+\mathrm{NO}_{2} \text {, as } \mathrm{N}\right)- & 15 & .1 & .96 \\ \text { Silica }\left(\mathrm{SiO}_{2}\right)- & 110 & 29 & 56.5\end{array}$

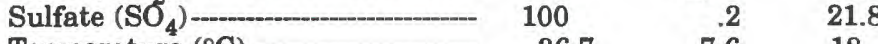

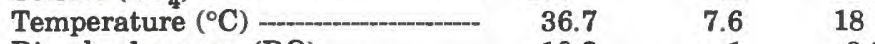

Dissolved oxygen (DO) -

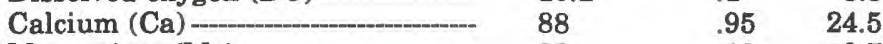

$\begin{array}{llll}\text { Magnesium }(\mathrm{Mg}) & 38 & .13 & 10.7\end{array}$

Fluoride (F) - $\quad 4.9 \quad 4.1$

$\begin{array}{lrrr}\text { Bicarbonate }\left(\mathrm{HCO}_{3}\right)- & 455 & 43 & 170.3 \\ \text { Iron }(\mathrm{Fe}) & 10 & .003 & .098\end{array}$

$\begin{array}{llll}\text { Iron }(\mathrm{Fe}) & 10 & .003 & .098 \\ \text { Potassium (K) - } & 13 & 1.1 & 4.7\end{array}$

$\begin{array}{llll}\mathrm{pH} \text { (units) - } & 9.4 & 6.7 & \text { 97.6 }\end{array}$

D. All three basalt units, 824 water analyses

Specific conductance (microsiemen

per centimeter at $25^{\circ} \mathrm{C}$ ). $\quad 1,970$

Calculated dissolved solids _._._._. 1,100

Sodium $(\mathrm{Na})$-.......... 130

Chloride (Cl) -

Nitrate+nitrite $\left(\mathrm{NO}_{3}+\mathrm{NO}_{2}\right.$, as $\left.\mathrm{N}\right)$ - 54

Silica $\left(\mathrm{SiO}_{2}\right)$

Sulfate $\left(\mathrm{SO}_{4}\right) \ldots$

Temperature $\left({ }^{\circ} \mathrm{C}\right) \ldots \quad 43.4$

Dissolved oxygen (DO) ______ $\quad 10.6$

Calcium (Ca) - $\quad 180$

Magnesium (Mg) …................

Fluoride (F) - $\quad 4.9$

Bicarbonate $\left(\mathrm{HCO}_{3}\right)$

Iron (Fe)

Potassium (K)

pH (units)
455

10
22

22

\begin{tabular}{cr}
85 & \multicolumn{1}{c}{385.6} \\
69 & 243 \\
2.4 & 40.4 \\
.5 & 14.9 \\
.1 & 2.9 \\
10 & 52.3 \\
.2 & 30.1 \\
6.2 & 16.7 \\
.1 & 4.5 \\
.8 & 30.8 \\
.1 & 14.1 \\
.1 & .53 \\
43 & 166.2 \\
.003 & .05 \\
.9 & 5.1 \\
6.1 & 87.5 \\
\hline
\end{tabular}

Mean value represents the negative base-10 log of the average hydrogen ion concentration in moles per liter.

The mean concentration of dissolved solids in water in the Saddle Mountains unit is about 340 $\mathrm{mg} / \mathrm{L}$ (table 7).

In the Wanapum unit, calcium magnesium sulfate chloride waters are generally found in wells shallower than $400 \mathrm{ft}$, in areas where the overburden is less than $200 \mathrm{ft}$ thick, and in areas where dissolved-oxygen concentrations in water are greater than $4.0 \mathrm{mg} / \mathrm{L}$ (fig. 49). The concentration of dissolved solids in the Wanapum unit had a mean of about $240 \mathrm{mg} / \mathrm{L}$. Sodium concentrations greater than $25 \mathrm{mg} / \mathrm{L}$ are found in downgradient and discharge areas. Nitrogen concentrations are generally less than $2.0 \mathrm{mg} / \mathrm{L}$ in waters from wells deeper than $500 \mathrm{ft}$. Larger nitrogen concentrations, greater than $10 \mathrm{mg} / \mathrm{L}$, are found in water from wells less than $300 \mathrm{ft}$ deep and where the overburden is thin or absent-generally in the central part of the plateau. The source of this dissolved nitrogen is unknown, but agricultural chemicals are the most likely source. The observed vertical variations in the nitrogen concentrations in the Wanapum unit probably are due to ground-waterflow patterns or to the possibility that nitrogenenriched water has not reached the deeper depths at this time; the former is the most likely case.

The mean concentration of dissolved solids of water in the Grande Ronde unit is about $234 \mathrm{mg} / \mathrm{L}$ and reflects the generally smaller concentrations of most solutes in this unit than in the other units. Sodium concentrations increase with residence time, and the largest concentrations are found in samples from the deepest wells. In general, sodium concentrations are larger in the central part of the plateau. Dissolved nitrogen is not a significant constituent in the Grande Ronde unit, and few 
concentrations were larger than $2.0 \mathrm{mg} / \mathrm{L}$. This is probably because the Grande Ronde unit is generally overlain by large thicknesses of the other basalts in the areas with intensive irrigation, and thus the water chemistry in the Grande Ronde unit is not affected by the infiltrating irrigation water.
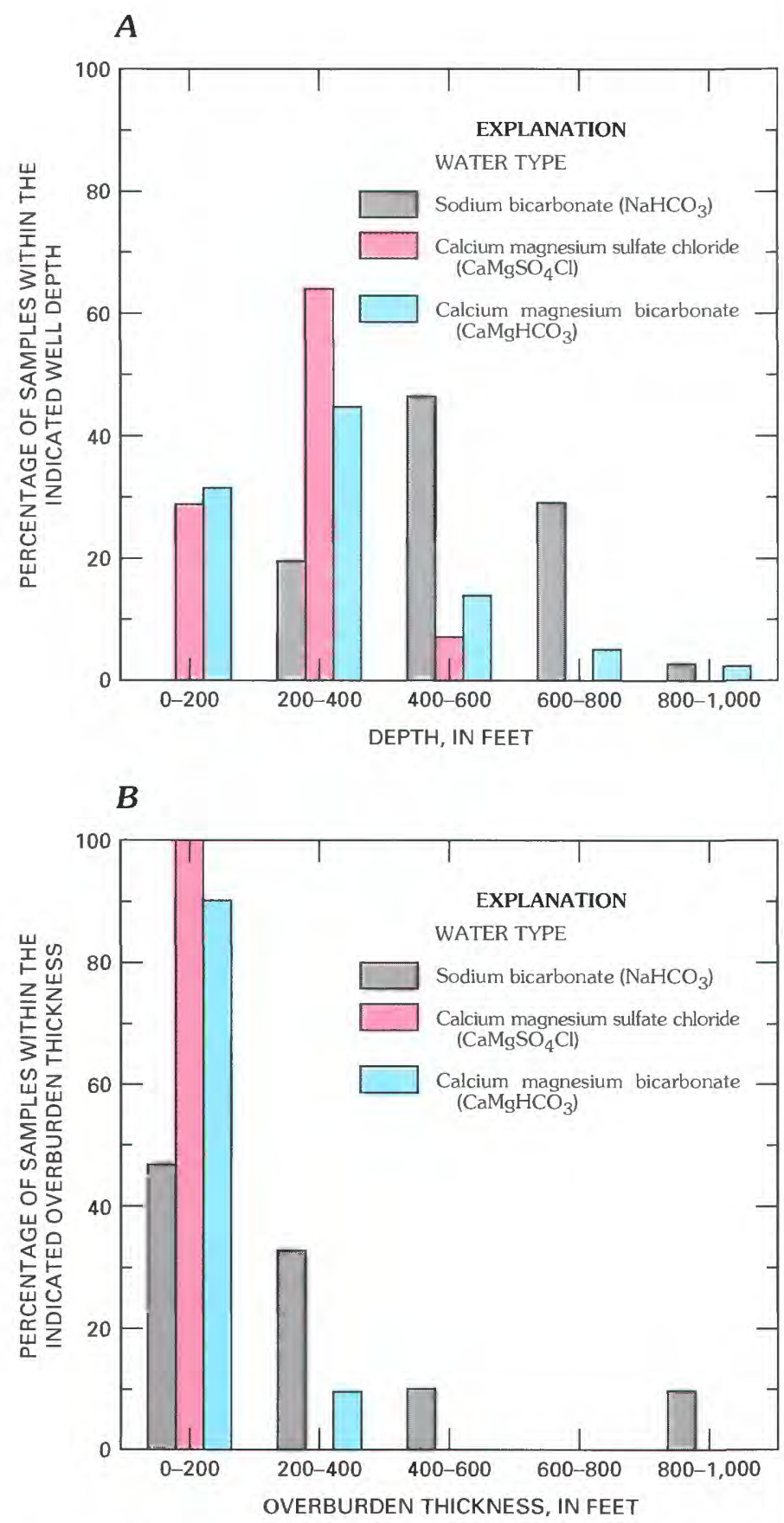

Figure 48.-Relation of chemical water type in the Saddle Mountains unit to $(A)$ well depth and $(B)$ overburden thickness (from Steinkampf, 1989).

\section{SUMMARY AND CONCLUSIONS}

The Columbia Plateau aquifer system underlies about $50,600 \mathrm{mi}^{2}$ in parts of Washington, Oregon, and Idaho. The aquifer system is a major source of water in one of the Nation's important agricultural areas. About 3,500 high-capacity wells pumped water from the aquifer system to irrigate nearly 0.5 million acres of cropland in 1984 .

The aquifer system consists of thick, water-bearing basalts of the Columbia River Basalt Group of Miocene age, and water-bearing sediments and sedimentary rocks of Miocene to Holocene age, overlying and intercalated with the basalts. The sediments and sedimentary rocks overlying the Columbia River Basalt Group are considered a composite unit of rock materials, termed overburden, that includes fluvial consolidated to unconsolidated deposits of lacustrine, volcanic, and eolian sediments. The overburden constitutes a water-table aquifer where saturated and has larger hydraulic-conductivity values than those of the basalts.

The three basalt formations of the Yakima Basalt Subgroup of the Columbia River Basalt Group constitute the bulk of the aquifer system. They are, from oldest to youngest, the Grande Ronde, Wanapum, and Saddle Mountains Basalts. The Grande Ronde Basalt is the thickest and most extensive of the three and consists of as many as 131 individual flows. The Wanapum Basalt overlies the Grande Ronde Basalt and is areally less extensive than the Grande Ronde Basalt; it consists of as many as 33 flows. The Saddle Mountains Basalt constitutes less than 2 percent of the total volume of the Columbia River Basalt Group and is limited areally to the central plateau.

The basalt forms an extremely complex, heterogeneous aquifer system with interflow zones that potentially function as small semiconfined to confined aquifers. The basalt transmits water most readily through these interflow zones, which represent about 5 to 10 percent of the total thickness of a typical basalt flow. Interflow zones are separated by less transmissive flow interiors with fractures. The density of fractures in the flow interiors differs greatly areally, and fractures are more vertically than laterally oriented. Ground-water flow in the flow interiors is probably vertical. Intercalated sediments within each formation range in lithologic character from shale to sands and gravels, and in most locations they are fine grained. Except in the Saddle Mountains Basalt, their thickness and extent are generally less than those of individual 
basalt flows, and the total thickness of these intercalated sediments is much less than the total thickness of that basalt formation. The two sedimentary interbeds between the basalt formations are fairly extensive laterally but are thin when compared with the thickness of a basalt formation. These interbeds may be locally transmissive and function as aquifers. However, the nature of their

A

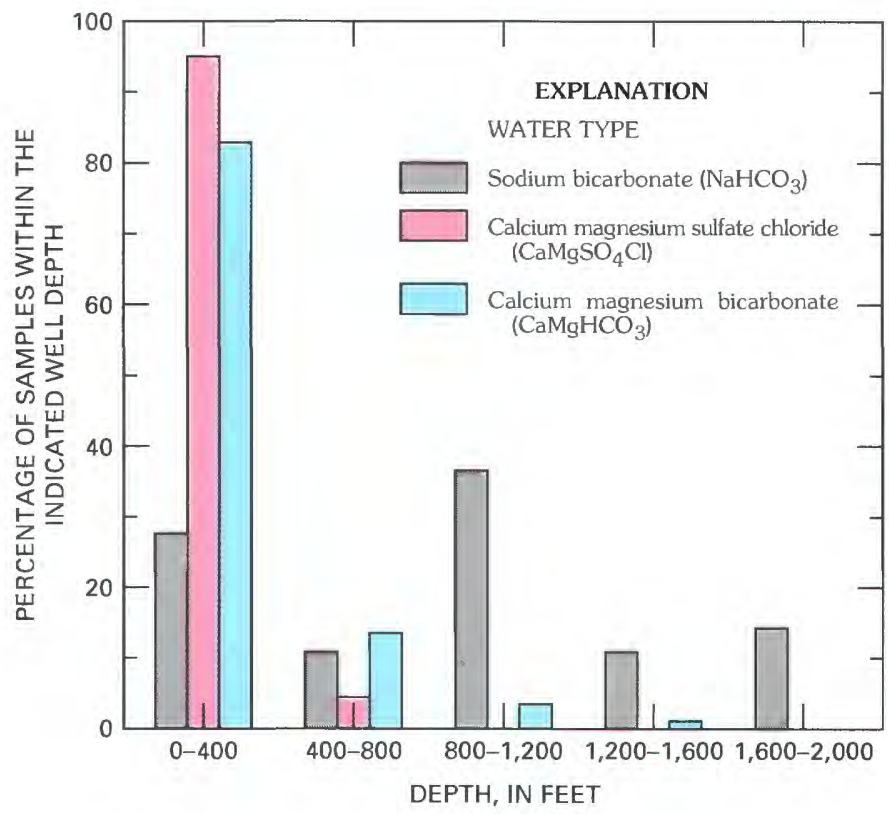

B

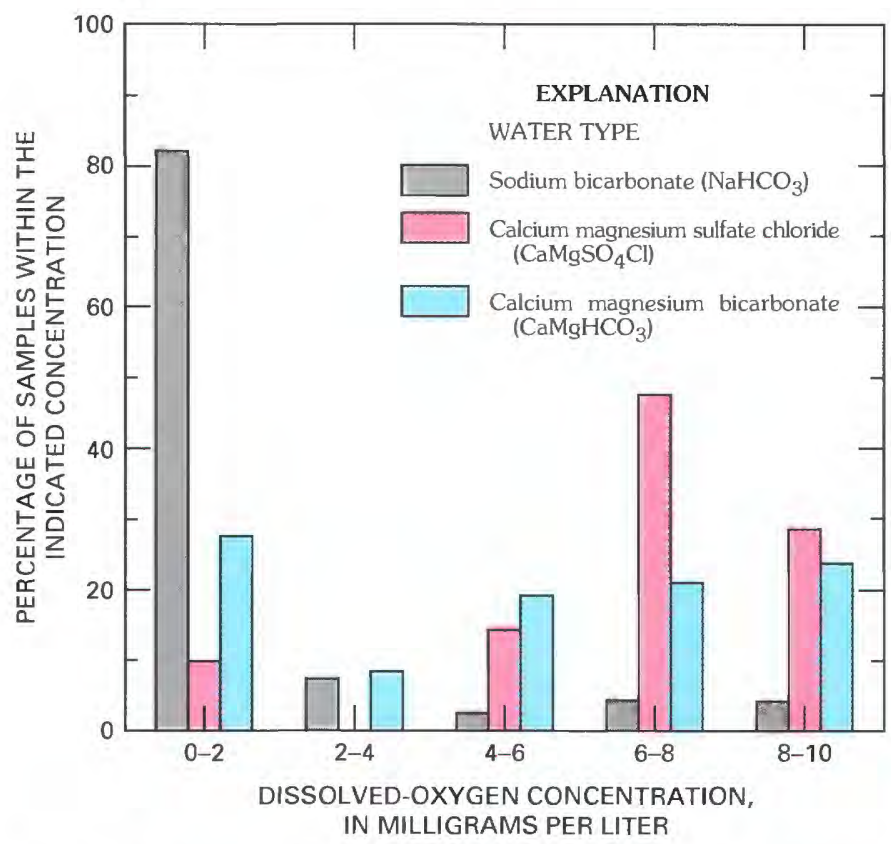

lithology indicates that they have low permeability and usually function as semiconfining or confining units.

A regional conceptual model that relates the geologic and hydrologic frameworks and provides a basis for evaluating the hydrologic system was developed during this study. In this model, the overburden is a water-table aquifer and is named

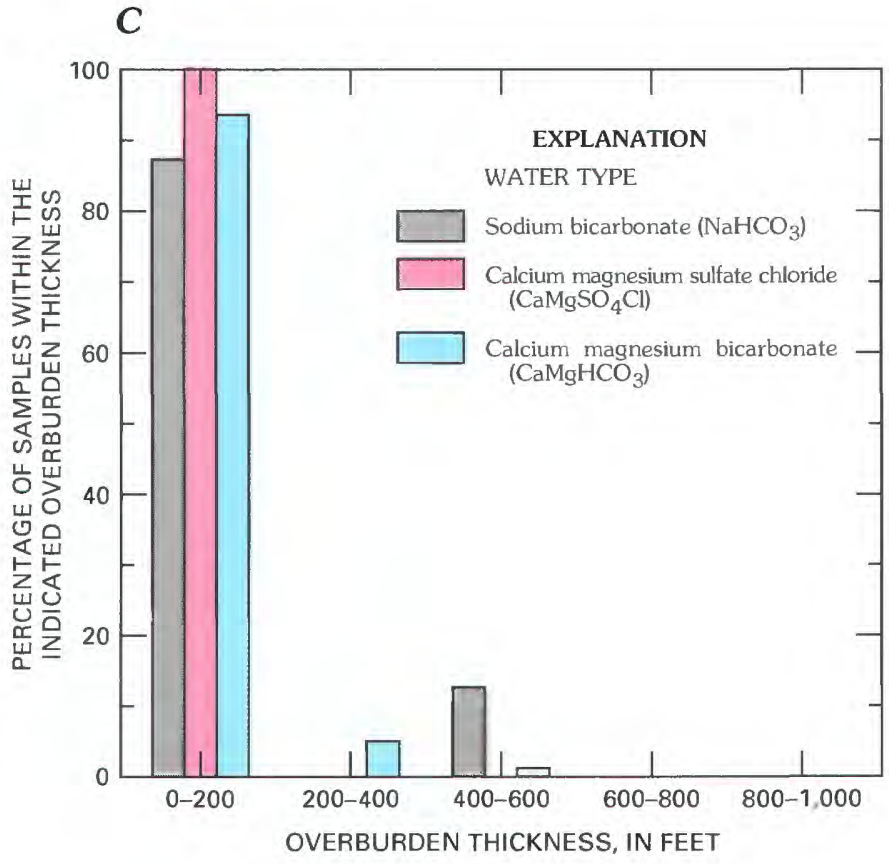

FIGURE 49.-Relation of chemical water type in the Wanapum unit to $(A)$ well depth, $(B)$ dissolved-oxygen concentration, and $(C)$ overburden thickness (from Steinkampf, 1989). 
the overburden aquifer. The basalt part of the aquifer system is subdivided into three units that correspond to the three basalt formations. Each unit includes the intercalated sediments but not the sedimentary interbeds between the basalt formations. The Saddle Mountains-Wanapum and Wanapum-Grande Ronde sedimentary interbeds are considered to be confining units. The prebasalt basement rocks generally have much lower permeability than the basalts. They are considered the bottom of the regional aquifer system and are named the basement confining unit. These six units compose the regional aquifer system.

The principal hydraulic characteristics of the aquifer system are hydraulic conductivity, specific yield, and storage coefficient. Specific-capacity data were used to estimate lateral hydraulic-conductivity values; for the overburden aquifer, the estimates were supplemented with data from previous studies. The median lateral hydraulic conductivity for the overburden aquifer was estimated to be about 240 $\mathrm{ft} / \mathrm{d}$, with 50 percent of the values about the median ranging from 45 to $1,000 \mathrm{ft} / \mathrm{d}$. Median values estimated for the three basalt units, youngest to oldest, are about 2,5 , and $5 \mathrm{ft} / \mathrm{d}$. Values of hydraulic conductivity for all three basalt units range from 0.005 to $6,100 \mathrm{ft} / \mathrm{d}$ and have a median of about $5 \mathrm{ft} / \mathrm{d}$.

The large range in hydraulic-conductivity values (from 0.02 to $150,000 \mathrm{ft} / \mathrm{d}$ ) for the overburden aquifer is due to the lithologic variety. The large range in lateral hydraulic-conductivity values in the basalts reflects their heterogeneous nature. The hydraulic-conductivity values estimated on the basis of specific-capacity data are integrated values for the depth of well penetration and thus are assumed to be estimates for the entire thickness of each unit. However, because they are integrated quantities, the lateral hydraulic conductivity of a productive zone can be larger than the estimated values.

The potential range in transmissivity for the aquifer system was estimated on the basis of thickness estimates and hydraulic-conductivity values. The thickness estimates were derived on the basis of discretization of each unit into blocks. A thickness value for each block in each unit was estimated from the thickness contours developed during the study. The potential range in transmissivity values for the aquifer system was obtained by multiplying the minima, medians, and maxima of estimated block thicknesses and estimated hydraulic-conductivity values. The estimated transmissivity of the aquifer system ranges from about
0.5 to 114 million $\mathrm{ft}^{2} / \mathrm{d}$, with a median of about $17,000 \mathrm{ft}^{2} / \mathrm{d}$. The estimated values probably are overestimated; however, they should be within an order of magnitude.

Vertical hydraulic conductivity is largely unknown. Values estimated from earlier modeling studies range from $0.5 \times 10^{-3}$ to $3.5 \mathrm{ft} / \mathrm{d}$, depending on the degree of fracturing and on the presence of pillow-palagonite complexes or geologic structures. The ratio of lateral to vertical hydraulic conductivity was estimated to be $1,000: 1$ to $100: 1$.

Specific-yield values of the overburden aquifer were estimated on the basis of previous studies and range from 0.0002 to 0.2 . The values of storage coefficient both obtained from earlier studies and estimated in this study for the basalt units range from $1.2 \times 10^{-6}$ to $1.1 \times 10^{-3}$.

The total ground-water discharge from the aquifer system cannot be estimated accurately because of the large streamflow in the Columbia, Snake, and Yakima River systems. Estimates of groundwater recharge on the plateau were computed independently for both predevelopment (1850's) and current (1980's) land-use conditions using a daily deep-percolation model. The model is an energysoils-water balance model that computes deep percolation below the effective root zone. Fifty-three basins were selected for estimates of recharge. The recharge values calculated for these basins were then used to develop a polynomial regression relation between the 22-yr average annual precipitation and the estimated recharge values. This relation then was used to estimate recharge for the remaining study area not included in the 53 selected basins.

The estimate of recharge for predevelopment conditions is about $6,000 \mathrm{ft}^{3} / \mathrm{s}$, and for current conditions is about $9,490 \mathrm{ft}^{3} / \mathrm{s}$. The areal distribution of recharge varies and depends on the timing and amount of precipitation, soil properties, land use, and topography.

Discharge from the aquifer system occurs principally as leakage to surface-water bodies and through springs and seeps along valley, canyon, and coulee walls. With the development of irrigated agricultural croplands, discharge also occurs as pumpage, increase in evapotranspiration in irrigated areas, and leakage to irrigation drains. About 67 percent $\left(2,346 \mathrm{ft}^{3} / \mathrm{s}\right)$ of the increased recharge under current conditions discharges to surface-water bodies, and the remainder discharges as pumpage.

An estimated 828,270 acre-ft of ground water was pumped from the Columbia Plateau in 1984 
from an estimated 3,500 high-capacity wells. Between 85 and 90 percent of the total pumpage was used for irrigation; the rest of the pumpage was used for public water supply and industrial uses. About 39 percent of the pumpage is from the Wanapum unit, 32 percent from the Grande Ronde unit, 26 percent from the overburden aquifer, and 3 percent from the Saddle Mountains unit. The highest pumpage is found in the central plateau in Washington and near Hermiston, Oregon.

Water in each unit generally flows from the peripheral boundary of each unit toward major surface-water bodies, principally the Columbia, Snake, and Yakima Rivers. Water-level changes have occurred in response to expansion of irrigation activities. The importation of surface water to the Columbia Basin Irrigation Project area has caused water-level rises throughout the area between the East Low Canal and the Columbia River to the west. Water-level rises exceed $300 \mathrm{ft}$ in the Quincy basin. Water-level declines in excess of 150 $\mathrm{ft}$ have resulted from pumpage in several localities east and south of the Columbia Basin Irrigation Project and in Oregon.

Water in the aquifer system is generally suitable for most uses. The dominant water type is calcium magnesium bicarbonate, and sodium bicarbonate is the next most prevalent water type. Sodium bicarbonate waters typically occur in deeper downgradient locations in the aquifer system. Sodium concentrations increase with residence time in the aquifer system. Large nitrogen concentrations in ground water are observed in areas of surfacewater irrigation.

\section{REFERENCES CITED}

Ames, L.L., 1980, Hanford basalt flow mineralogy: Richland, Wash., Pacific Northwest Laboratory Report INL-2847, $447 \mathrm{p}$.

Barker, R.A., and MacNish, R.D., 1976, Digital model of the gravel aquifer, Walla Walla River basin, Washington and Oregon: Washington Department of Ecology Water-Supply Bulletin 45, $49 \mathrm{p}$.

Barrash, Warren, Bond, J.G., and Venkatakrishnan, Ramesh, 1983, Structural evolution of the Columbia Plateau in Washington and Oregon: American Journal of Science, $v$. 283 , p. 897-935.

Bauer, H.H., and Vaccaro, J.J., 1987, Documentation of a deep percolation model for estimating ground-water recharge: U.S. Geological Survey Open- File Report 86-536, 180 p. -1990 , Estimates of ground-water recharge to the Columbia Plateau regional aquifer system, Washington, Oregon, and Idaho, for predevelopment and current land-use conditions: U.S. Geological Survey Water-Resources Investigations Report 88-4108, 37 p., 2 plates.

Bauer, H.H., Vaccaro, J.J., and Lane, R.C., 1985, Maps showing ground-water levels in the Columbia River Basalt and overlying material, spring 1983, southeastern Washington: U.S. Geological Survey Water-Resources Investigations Report $84-4360,4$ sheets.

Benson, L.V., and Teague, L.S., 1982, Diagenesis of basalts from the Pasco Basin, Washington-I. Distribution and composition of secondary mineral phases: Journal of Sedimentary Petrology, v. 52, no. 2, p. 595-613.

Bierschenk, W.H., 1959, Aquifer characteristics and groundwater movement at Hanford: unclassified Atomic Energy Commission Research and Development report, p. 33.

Bingham, J.W., and Grolier, M.J., 1966, The Yakima Basalt and Ellensburg Formation of south-central Washington: U.S. Geological Survey Bulletin 1224-G, 15 p.

Bingham, J.W., and Walters, K.L., 1965, Stratigraphy of the upper part of the Yakima Basalt in Whitman and eastern Franklin Counties, Washington, in Geological Survey Research 1965: U.S. Geological Survey Professional Paper 525-C, p. C87-C90.

Bolke, E.L., and Skrivan, J.A., 1981, Digital-model simulation of the Toppenish alluvial aquifer, Yakima Indian Reservation, Washington: U.S. Geological Survey Water-Resources Investigations Open-File Report $81-425,34 \mathrm{p}$.

Bretz, J H., 1923a, Glacial drainage on the Columbia Plateau: Geological Society of America Bulletin, v. 34, p. 573-608. $1923 \mathrm{~b}$, The channeled scablands of the Columbia Plateau: Journal of Geology, v. 31, p. 617-649.

Calkins, F.C., 1905, Geology and water resources of a portion of east-central Washington: U.S. Geological Survey WaterSupply Paper 118, 96 p.

Cline, D.R., 1984, Ground-water levels and pumpage in eastcentral Washington, including the Odessa-Lind area, 1967 to 1981: Washington Department of Ecology Water-Supply Bulletin 55, $34 \mathrm{p}$.

Cline, D.R., and Knadle, M.E., 1990, Ground-water pumpage from the Columbia Plateau regional aquifer system, Washington, 1984: U.S. Geological Survey Water-Resources Investigations Report $87-4135,32$ p., 1 sheet.

Collins, C.A., 1987, Ground-water pumpage from the Columbia Plateau regional aquifer system, Oregon, 1984: U.S. Geological Survey Water-Resources Investigations Report 864211, $21 \mathrm{p}$.

Davies-Smith, A., Bolke, E.L., and Collins, C.A., 1988, Geohydrology and digital simulation of the ground-water flow system in the Umatilla Plateau and Horse Heaven Hills area, Oregon and Washington: U.S. Geological Survey Water-Resources Investigations Report 87-4268, $70 \mathrm{p}$.

Diery, H.D., and McKee, Bates, 1969, Stratigraphy of the Yakima Basalt in the type area: Northwest Science, v. 43, p. 47-64.

Drost, B.W., and Whiteman, K.J., 1986, Surficial geology, structural features, and thickness and tops of selected geohydrologic units in the Columbia Plateau, Washington: U.S. Geological Survey Water-Resources Investigations Report 84-4326, 10 sheets.

Drost, B.W., Whiteman, K.J., and Gonthier, J.B., 1990, The geologic framework of the Columbia Plateau regional aquifer system, Washington, Oregon, and Idaho: U.S. Geological Survey Water-Resources Investigations Report $87-4238,10$ p., 10 sheets.

Eddy, P.A., 1976, Description, preliminary results, and pumping tests-Observation well 13 near George, Washington: Washington Department of Ecology Water-Resources Information Series, Technical Bulletin 19, 43 p.

Elassal, A.A., and Caruso, V.M., 1983, USGS digital carto- 
graphic data standards: Digital elevation models: U.S. Geological Survey Circular 895-B, 40 p.

Farooqui, S.M., Beaulieu, J.B., Bunker, R.C., Stensland, D.E., and Thoms, R.E., 1981, Dalles Group: Neogene formations overlying the Columbia River Basalt Group in northcentral Oregon: Oregon Department of Geology and Mineral Industries, Oregon Geology, v. 43, no. 10, p. 131-140.

Ferris, J.G., Knowles, D.B., Brown, R.H., and Stallman, R.W., 1962, Theory of aquifer tests: U.S. Geological Survey Water-Supply Paper 1536-E, 174 p.

Flint, R.F., 1938, Summary of late-Cenozoic geology of southeastern Washington: American Journal of Science, v. 35, p. 223-230.

Freeman, O.W., Forrester, J.O., and Lupher, R.L., 1945, Physiographic divisions of the Columbia Intermontane Province: Association of American Geographers Annals, v. 35, no. 2, p. 50-75.

Fuller, R.E., 1931, The aqueous chilling of basaltic lava on the Columbia River Plateau: American Journal of Science, v. 21, p. 281-300.

Gonthier, J.B., 1990, Geology, structure, and thickness of hydrogeologic units in part of the Columbia Plateau, Oregon: U.S. Geological Survey Water- Resources Investigations Report 86-4001, 6 sheets.

Grolier, M.J., and Foxworthy, B.L., 1961, Geology of the Moses Lake North quadrangle, Washington: U.S. Geological Survey Miscellaneous Geologic Investigations Map I-330, scale $1: 24,000$

Hearn, P.P., Steinkampf, W.C., Bortleson, G.C., and Drost, B.W., 1985, Geochemical controls on dissolved sodium in basalt aquifers of the Columbia Plateau, Washington: U.S. Geological Survey Water-Resources Investigations Report 84-4304, 38 p.

Hooper, P.R., 1982, The Columbia River Basalts: Science, v. 215 , no. 4539 , p. $1,463-1,468$.

IMSL, 1982, Interpolation, chapter I, in International mathematics and science library reference manual, v. 2: Houston, Texas, IMSL, Inc.

Jacob, C.E., 1940, On the flow of water in an elastic artesian aquifer: Transactions of the American Geophysical Union, v. 21 , pt. 2 , p. $574-586$.

Jones, B.F., 1966, Geochemical evolution of closed basin water in the western Great Basin, in Rau, J.L., ed., Second Symposium on Salt: Northern Ohio Geological Society, v. 1, p. 181-200.

Lane, R.C., and Whiteman, K.J., 1989, Ground-water levels, spring 1985, and ground-water level changes, spring 1983 to spring 1985, in three basalt units underlying the Columbia Plateau, Washington and Oregon: U.S. Geological Survey Water-Resources Investigations Report 88-4018, 4 sheets.

LaSala, A.M., Jr., and Doty, G.C., 1971, Preliminary evaluation of hydrologic factors related to radioactive waste storage in basaltic rocks at the Hanford Reservation, Washington: U.S. Geological Survey Open-File Report 71-180, 80 p.

Lohman, S.W., and others, 1972, Definitions of selected groundwater terms-Revisions and conceptual refinements: U.S Geological Survey Water-Supply Paper 1988, 21 p.

Luzier, J.E., Bingham, J.W., Burt, R.J., and Barker, R.A., 1968 , Ground water survey, Odessa-Lind area, Washington: Washington Department of Water-Resources Water-Supply Bulletin $36,31 \mathrm{p}$.

Luzier, J.E., and Skrivan, J.A., 1975, Digital simulation and projection of water-level declines in basalt aquifers of the Odessa-Lind area, east- central Washington: U.S. Geological Survey Water-Supply Paper 2036, 48 p.

Mackin, J.H., 1961, A stratigraphic section in the Yakima Basalt and the Ellensburg Formation in south-central Washington: Washington Division of Mines and Geology Report Investigations $19,45 \mathrm{p}$.

MacNish, R.D., and Barker, R.A., 1976, Digital simulation of a basalt aquifer system, Walla Walla River basin, Washington and Oregon: Washington Department of Ecology Water-Supply Bulletin 44, $51 \mathrm{p}$.

Mundorff, M.J., MacNish, R.D., and Cline, D.R., 1977, Water resources of the Satus Creek Basin, Yakima Indian Reservation, Washington: U.S. Geological Survey Open-File Report 76-685, $102 \mathrm{p}$.

Myers, C.W., and Price, S.M., 1979, Geologic studies of the Columbia Plateau, a status report: Richland, Wash., Rockwell International, Rockwell Hanford Operations Report RHOBWI-ST-4, $520 \mathrm{p}$.

Nelson, L.M., 1991, Surface-water resources for the Columbia Plateau, Washington, Oregon, and Idaho: U.S. Geological Survey Water-Resources Investigations Report 88-4105, 4 sheets.

Newcomb, R.C., 1961, Storage of ground water behind subsurface dams in the Columbia River Basalt, Washington and Idaho: U.S. Geological Survey Professional Paper 383-A, $15 \mathrm{p}$.

1965, Geology and ground-water resources of the Walla Walla River basin, Washington-Oregon: Washington Division of Water Resources Water-Supply Bulletin 21, $151 \mathrm{p}$.

1969, Effect of tectonic structure on the occurrence of ground water in the basalt of the Columbia River Group of The Dalles area, Oregon and Washington: U.S. Geological Survey Professional Paper 383-C, 33 p.

Newcomb, R.C., Strand, J.R., and Frank, F.J., 1972, Geology and ground-water characteristics of the Hanford Reservation of the U.S. Atomic Energy Commission, Washington: U.S. Geological Survey Professional Paper 717, 78 p.

Pacific Northwest River Basins Commission, 1971, Columbianorth Pacific region comprehensive framework study, Appendix IX: Irrigation: Vancouver, Wash., $343 \mathrm{p}$.

Pardee, J.T., and Bryan, Kirk, 1926, Geology of the Latah Formation in relation to the lavas of the Columbia Plateau near Spokane, Washington: U.S. Geological Survey Professional Paper 140-A, p. 1-16.

Piper, A.M., 1932, Geology and ground-water resources of the Dalles region, Oregon: U.S. Geological Survey WaterSupply Paper 659-B, p. 107-189.

Price, C.E., 1960, Artificial recharge of a well tapping basalt aquifers, Walla Walla area, Washington: Washington Division of Water Resources Water-Supply Bulletin 7, 50 p.

Prych, E.A., 1983, Numerical simulation of ground-water flow in lower Satus Creek basin, Yakima Indian Reservation, Washington: U.S. Geological Survey Water-Resources Investigations Report 82-4065, $78 \mathrm{p}$.

Reidel, S.P., 1982, Stratigraphy of the Grande Ronde Basalt, Columbia River Basalt Group, from the lower Salmon River and northern Hells Canyon area, Idaho, Oregon, and Washington, in Bonnichsen, Bill, and Breckenridge, R.M., eds., Cenozoic geology of Idaho: Idaho Bureau of Mines and Geology Bulletin 26, p. 77-101.

1984, The Saddle Mountains: The evolution of an anticline in the Yakima Fold Belt: American Journal of Science, v. 284, p. 942-978.

Russell, I.C., 1893, A geological reconnaissance in central Washington: U.S. Geological Survey Bulletin 108, 108 p. 1897, A reconnaissance of southeastern Washington: U.S. Geological Survey Water-Supply Paper 4, 96 p.

Schmincke, H.U., 1965, Tracing a basalt flow on the Columbia 
River Plateau, south-central Washington [abs.]: Geological Society of America Special Paper 82, p. 275-276.

1967a, Fused tuff and peperites in south-central Washington: Geological Society of America Bulletin, v. 78, no. 3, p. $319-330$.

1967b, Stratigraphy and petrography of four upper Yakima Basalt flows in south-central Washington: Geological Society of America Bulletin, v. 78, p. 1,385-1,422.

Schwennesen, A.T., and Meinzer, O.E., 1918, Ground water in Quincy Valley, Washington: U.S. Geological Survey WaterSupply Paper 425-E, p. 131-161.

Smith, G.O., 1901, Geology and water resources of a portion of Yakima County, Washington: U.S. Geological Survey Water-Supply Paper 55, 68 p.

1903a, Description of the Ellensburg quadrangle, Washington: U.S. Geological Survey Atlas, Folio 86, 7 p.

1903b, Anticlinal mountain ridges in central Washington: Journal of Geology, v. 11, p. 166-177.

1903c, Geology and physiography of central Washington U.S. Geological Survey Professional Paper 19, p. 9-39.

Stearns, R.T., 1942, Hydrology of lava-rock terranes, chap. XV, in Meinzer, O.E., ed., Hydrology: New York, McGraw-Hill, 712 p.

Steinkampf, W.C., 1989, Water-quality characteristics of the Columbia Plateau regional aquifer system in parts of Washington, Oregon, and Idaho: U.S. Geological Survey Water-Resources Investigations Report 87-4242, 37 p.

Steinkampf, W.C., Bortleson, G.C., and Packard, F.A., 1985, Controls on ground-water chemistry in the Horse Heaven Hills, south-central Washington: U.S. Geological Survey Water-Resources Investigations Report 85-4048, 26 p.

Sublette, W.R., 1986, Rock mechanics data package, Rev. 1: Richland, Wash., Rockwell Hanford Operations Report SDBWI-DP-041, 78 p.

Swanson, D.A., 1967, Yakima Basalt of the Tieton River area, south-central Washington: Geological Society of America Bulletin, v. 78 , p. 1,077-1,110.

Swanson, D.A., Anderson, J.L., Bentley, R.D., Byerly, G.R., Camp, V.E., Gardner, J.N., and Wright, T.L., 1979a, Reconnaissance geologic map of the Columbia River Basalt Group in eastern Washington and northern Idaho: U.S. Geological Survey Open-File Report 79-1363, 26 p., 12 sheets, scale 1:250,000.

Swanson, D.A., Anderson, J.L., Camp, V.E., Hooper, P.R. Taubeneck, W.H., and Wright, T.L., 1981, Reconnaissance geologic map of the Columbia River Basalt Group, northern Oregon and western Idaho: U.S. Geological Survey Open-File Report 81-797, 35 p.

Swanson, D.A., Brown, J.C., Anderson, J.L., Bentley, R.D., Byerly, G.R., Gardner, J.N., and Wright, T.L., 1979b, Preliminary structure contour maps on the top of the Grande Ronde and Wanapum Basalts, eastern Washington and northern Idaho: U.S. Geological Survey Open-File Report 79-1364, 2 sheets, scale 1:500,000.

Swanson, D.A., and Wright, T.L., 1978, Bedrock geology of the southern Columbia Plateau and adjacent areas, chap. 3 , in Baker, V.R., and Nummedal, D., eds., The channeled scabland: Washington, D.C., Planetary Geology Program, National Aeronautical and Space Administration, p. 37-57.

Swanson, D.A., Wright, T.L., and Helz, R.T., 1975, Linear vent systems and estimated rates of magma production and eruption for the Yakima Basalt on the Columbia Plateau: American Journal of Science, v. 275, Oct. 1975, p. 877-905.

Swanson, D.A., Wright, T.L., Hooper, P.R., and Bentley, R.D., 1979c,
Revisions in stratigraphic nomenclature of the Columbia River Basalt Group: U.S. Geological Survey Bulletin 1457-G, 59 p.

Swanson, D.A., Wright, T.L., and Zeitz, I., 1979d, Aeromagnetic map and geologic interpretation of the west-central Columbia Plateau, Washington and adjacent Oregon: U.S. Geological Survey Geophysical Investigations Map GP-917, scale 1:250,000.

Tanaka, H.H., Barrett, G.T., and Wildrick, L., 1979, Regional basalt hydrology of the Columbia Plateau in Washington: Richland, Wash., Rockwell Hanford Operations Report RHO-BWI-C-60, 303 p.

Tanaka, H.H., Hansen, A.J., Jr., and Skrivan, J.A., 1974, Digital-model study of ground-water hydrology, Columbia Basin Irrigation Project area, Washington: Washington Department of Ecology Water-Supply Bulletin 40,60 p.

Taylor, G.C., Jr., 1948, Ground water in the Quincy Basin, Wahluke Slope, and Pasco Slope subareas of the Columbia Basin Project, Washington: U.S. Geological Survey openfile report, $182 \mathrm{p}$.

Theis, C.V., 1963, Estimating the transmissibility of a watertable aquifer from the specific capacity of a well, in Bentall, Ray, compiler, Methods of determining permeability, transmissibility, and drawdown: U.S. Geological Survey Water-Supply Paper 1536-I, p. 332-336.

Tolan, T.L., Reidd, S.P., Beeson, M.H., Anderson, J.L., Fecht, K.R., and Swanson, D.A., 1987, Revisions to the areal extent and volume of the Columbia River Basalt Group [abs.]: Geological Society of America Abstracts with Programs, v. 19 , no. 6 , p. 458 .

U.S. Department of Commerce, 1982, Census of Agriculture, part 47, Washington: Bureau of the Census, 261 p. (Also for $1978,1974,1969,1964,1959,1954$, and 1949.)

U.S. Geological Survey, 1975, Water resources of the Toppenish Creek basin, Yakima Indian Reservation, Washington: U.S. Geological Survey Water- Resources Investigations Report 42-74, $144 \mathrm{p}$.

Waring, G.A., 1913, Geology and water resources of a portion of south-central Washington: U.S. Geological Survey WaterSupply Paper 316, 46 p.

Washington State Department of Ecology, 1974, Inventory and reconnaissance of irrigation districts in the State of Washington: Olympia, Wash., URS/Hill, Ingman, Chase and Co., $3 \mathrm{v}$.

Waters, A.C., 1955, Geomorphology of south-central Washington, illustrated by the Yakima East quadrangle: Geological Society of America Bulletin, v. 66, no. 6, p. 663-684.

1961, Stratigraphic and lithologic variations in the Columbia River Basalt: American Journal of Science, v. 259, no. 8, p. 583-611.

Whiteman, K.J., 1986, Ground-water levels in three basalt hydrologic units underlying the Columbia Plateau in Washington and Oregon, spring 1984: U.S. Geological Survey Water-Resources Investigations Report 86-4046, 4 sheets.

Wood, W., and Fernandez, L.A., 1988, Volcanic rocks, chap. 39, in Back, W., Rosenshein, J.S., and Seaber, P.R., eds., Hydrogeology, the geology of North America, v. O-2: Boulder, Colo., Geological Society of America, Decade of North American Geology Project, p. 353-365.

Wukelic, G.E., Foote, H.P., Blair, S.C., and Begej, C.D., 1981, Monitoring land- and water-use dynamics in the Columbia Plateau using remote-sensing computer analysis and integration techniques: Richland, Wash., Rockwell International Report RHO-BW-CR-122P/PNL-4047, 50 p. 



\section{SELECTED SERIES OF U.S. GEOLOGICAL SURVEY PUBLICATIONS}

\section{Periodicals}

Earthquakes \& Volcanoes (issued bimonthly).

Preliminary Determination of Epicenters (issued monthly).

\section{Technical Books and Reports}

Professional Papers are mainly comprehensive scientific reports of wide and lasting interest and importance to professional scientists and engineers. Included are reports on the results of resource studies and of topographic, hydrologic, and geologic investigations. They also include collections of related papers addressing different aspects of a single scientific topic.

Bulletins contain significant data and interpretations that are of lasting scientific interest but are generally more limited in scope or geographic coverage than Professional Papers. They include the results of resource studies and of geologic and topographic investigations, as well as collections of short papers related to a specific topic.

Water-Supply Papers are comprehensive reports that present significant interpretive results of hydrologic investigations of wide interest to professional geologists, hydrologists, and engineers. The series covers investigations in all phases of hydrology, including hydrogeology, availability of water, quality of water, and use of water.

Circulars present administrative information or important scientific information of wide popular interest in a format designed for distribution at no cost to the public. Information is usually of shortterm interest.

Water-Resource Investigations Reports are papers of an interpretive nature made available to the public outside the formal USGS publications series. Copies are reproduced on request unlike formal USGS publications, and they are also available for public inspection at depositories indicated in USGS catalogs.

Open-File Reports include unpublished manuscript reports, maps, and other material that are made available for public consultation at depositories. They are a nonpermanent form of publication that may be cited in other publications as sources of information.

\section{Maps}

Geologic Quadrangle Maps are multicolor geologic maps on topographic bases in 7 1/2-or 15 -minute quadrangle formats (scales mainly $1: 24,000$ or $1: 62,500$ ) showing bedrock, surficial, or engineering geology. Maps generally include brief texts; some maps include structure and columnar sections only.

Geophysical Investigations Maps are on topographic or planimetric bases at various scales; they show results of surveys using geophysical techniques, such as gravity, magnetic, seismic, or radioactivity, which reflect subsurface structures that are of economic or geologic significance. Many maps include correlations with the geology.

Miscellaneous Investigations Series Maps are on planimetric or topographic bases of regular and irregular areas at various scales; they present a wide variety of format and subject matter. The series also includes 7 1/2-minute quadrangle photogeologic maps on planimetric bases that show geology as interpreted from aerial photographs. Series also includes maps of Mars and the Moon.
Coal Investigations Maps are geologic maps on topographic or planimetric bases at various scales showing bedrock or surficial geology, stratigraphy, and structural relations in certain coal-resource areas.

Oil and Gas Investigations Charts show stratigraphic information for certain oil and gas fields and other areas having petroleum potential.

Miscellaneous Field Studies Maps are multicolor or black-andwhite maps on topographic or planimetric bases on quadrangle or irregular areas at various scales. Pre-1971 maps show bedrock geology in relation to specific mining or mineral-deposit problems; post-1971 maps are primarily black-and-white maps on various subjects, such as environmental studies or wilderness mineral investigations.

Hydrologic Investigations A tlases are multicolor or black-andwhite maps on topographic or planimetric bases presenting a wide range of geohydrologic data of both regular and irregular areas; principal scale is $1: 24,000$, and regional studies are at $1: 250,000$ scale or smaller.

\section{Catalogs}

Permanent catalogs, as well as some others, giving comprehensive listings of U.S. Geological Survey publications are available under the conditions indicated below from the U.S. Geological Survey, Books and Open-File Reports Sales, Federal Center, Box 25286, Denver, CO 80225. (See latest Price and Availability List.)

"Publications of the Geological Survey, 1879-1961" may be purchased by mail and over the counter in paperback book form and as a set of microfiche.

"Publications of the Geological Survey, 1962-1970" may be purchased by mail and over the counter in paperback book form and as a set of microfiche.

"Publications of the Geological Survey, 1971-1981" may be purchased by mail and over the counter in paperback book form (two volumes, publications listing and index) and as a set of microfiche.

Supplements for $1982,1983,1984,1985,1986$, and for subsequent years since the last permanent catalog may be purchased by mail and over the counter in paperback book form.

State catalogs, "List of U.S. Geological Survey Geologic and Water-Supply Reports and Maps For (State)," may be purchased by mail and over the counter in paperback booklet form only.

"Price and Availability List of U.S. Geological Survey Publications," issued annually, is available free of charge in paperback booklet form only.

Selected copies of a monthly catalog "New Publications of the U.S. Geological Survey" are available free of charge by mail or may be obtained over the counter in paperback booklet form only. Those wishing a free subscription to the monthly catalog "New Publications of the U.S. Geological Survey" should write to the U.S. Geological Survey, 582 National Center, Reston, VA 22092.

Note.-Prices of Government publications listed in older catalogs, announcements, and publications may be incorrect. Therefore, the prices charged may differ from the prices in catalogs, announcements, and publications. 


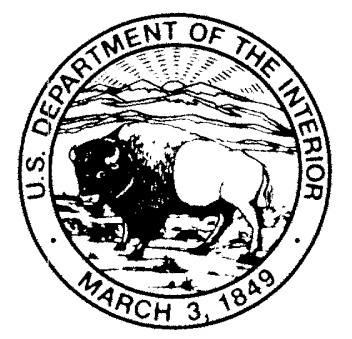

